\title{
Identifying Bird and Reptile Vulnerabilities to Climate Change in the Southwestern United States
}

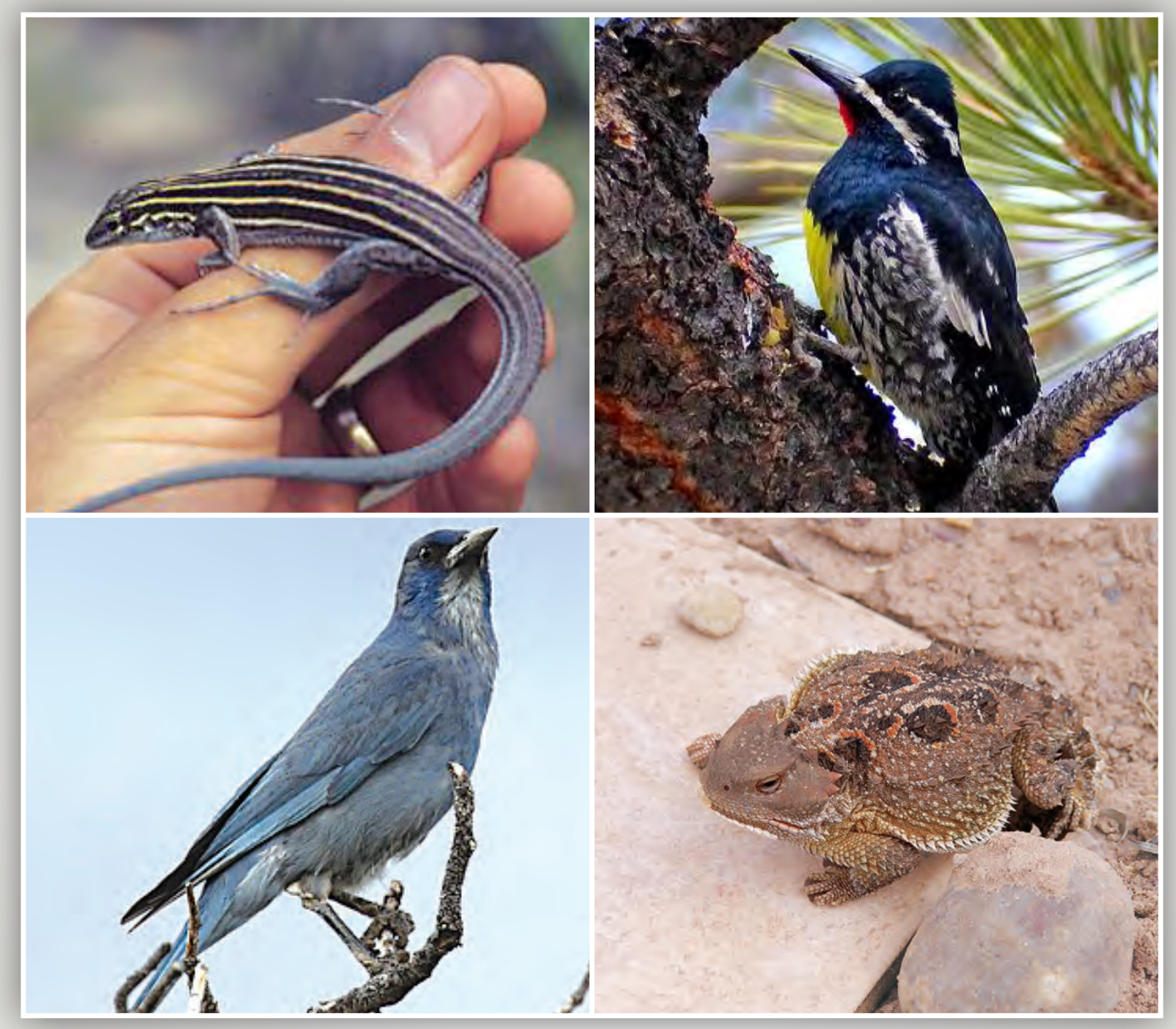

Open-File Report 2016-1085

U.S. Department of the Interior

U.S. Geological Survey 
Cover: Cover photograph description clockwise from upper left: Plateau Striped Whiptail (Aspidscelis velox) byTrevor B. Persons, Northern Arizona University (2007); Red-naped Sapsucker (Sphyrapicus nuchalis) by Len Blumin, Flickr (January 2014);

Greater Short-horned Lizard (Phrynosoma hernandesi) by Erika Nowak, Northern Arizona University (2007); and

Pinyon Jay (Gymnorhinus cyanocephalus) by Erin, Adventures with E\&L (July 2010). 


\section{Identifying Bird and Reptile Vulnerabilities to Climate Change in the Southwestern United States}

By James R. Hatten, J. Tomasz Giermakowski, Jennifer A. Holmes, Erika M. Nowak, Matthew J. Johnson, Kirsten E. Ironside, Charles van Riper III, Michael Peters, Charles Truettner, and Kenneth L. Cole

Open-File Report 2016-1085

U.S. Department of the Interior

U.S. Geological Survey 


\section{U.S. Department of the Interior \\ SALLY JEWELL, Secretary}

\section{U.S. Geological Survey \\ Suzette M. Kimball, Director}

U.S. Geological Survey, Reston, Virginia: 2016

For more information on the USGS—-the Federal source for science about the Earth,

its natural and living resources, natural hazards, and the environment-visit

http://www.usgs.gov/ or call 1-888-ASK-USGS (1-888-275-8747).

For an overview of USGS information products, including maps, imagery, and publications, visit http://store.usgs.gov.

Any use of trade, firm, or product names is for descriptive purposes only and does not imply endorsement by the U.S. Government.

Although this information product, for the most part, is in the public domain, it also may contain copyrighted materials as noted in the text. Permission to reproduce copyrighted items must be secured from the copyright owner.

Suggested citation:

Hatten, J.R., Giermakowski, J.T., Holmes, J.A., Nowak, E.M., Johnson, M.J., Ironside, K.E., van Riper, Charles, III, Peters, Michael, Truettner, Charles, and Cole, K.L., 2016, Identifying bird and reptile vulnerabilities to climate change in the Southwestern United States: U.S. Geological Survey Open-File Report 2016-1085, 76 p., http://dx.doi.org/10.3133/ofr20161085. 


\section{Contents}

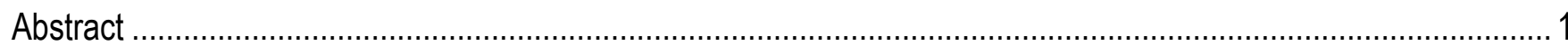

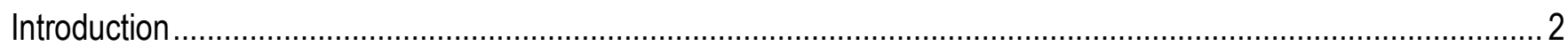

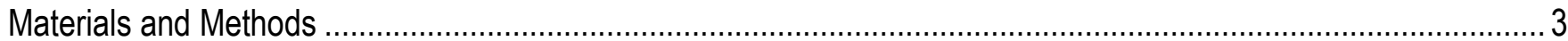

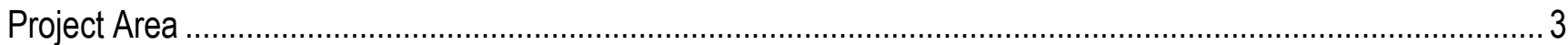

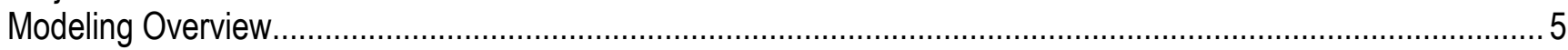

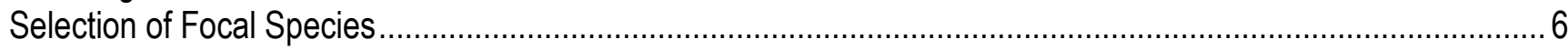

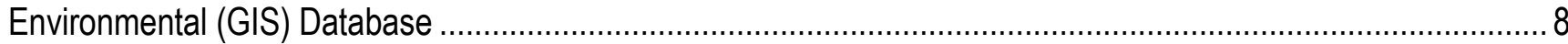

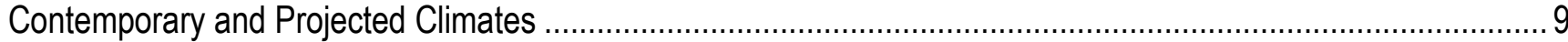

Species Distribution Models........................................................................................................... 10

Projecting Climate Effects on Species Range .................................................................................... 11

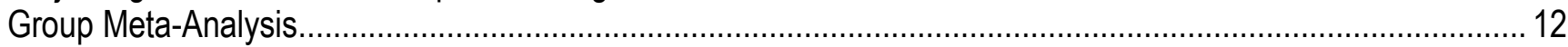

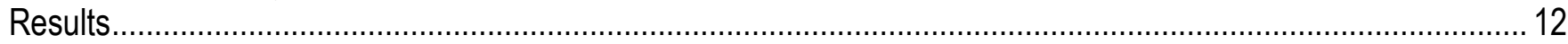

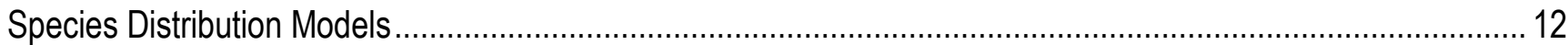

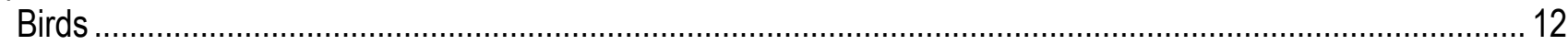

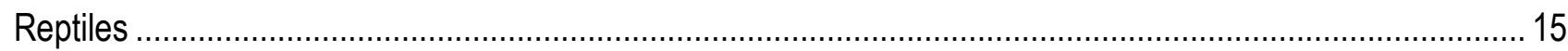

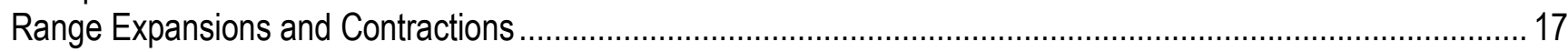

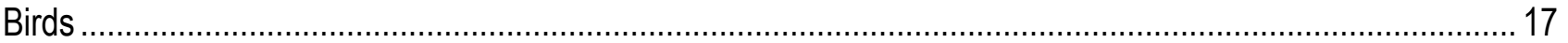

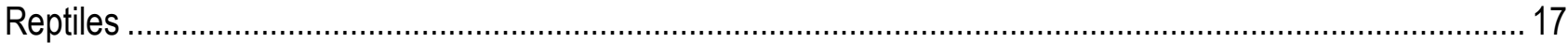

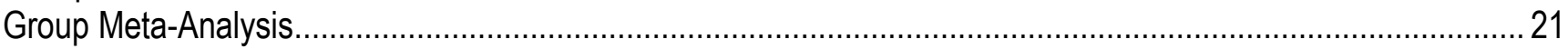

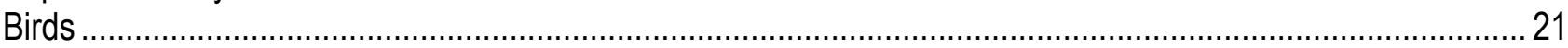

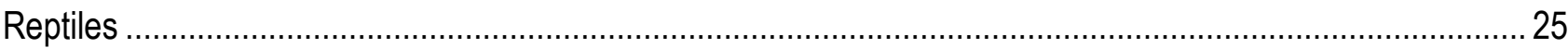

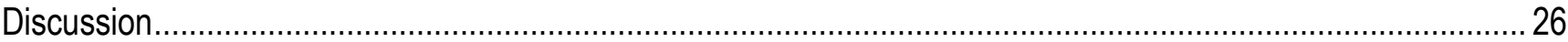

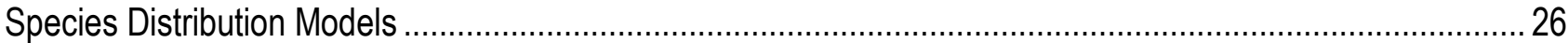

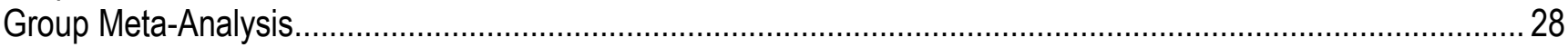

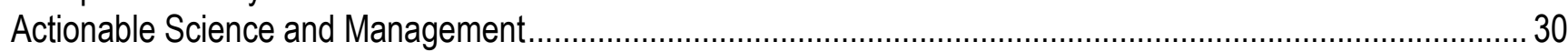

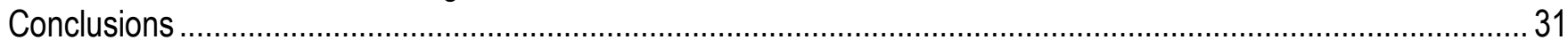

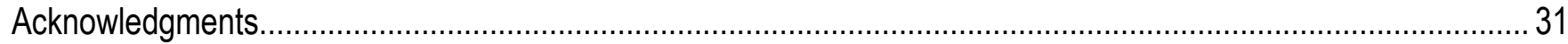

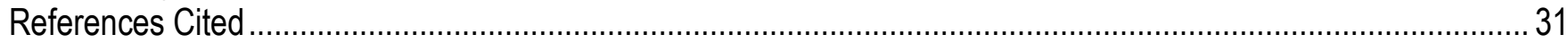

Appendix 1. Bird and Reptile Distribution Data and Processing Steps ............................................................ 40

Appendix 2. Plant Distributions, Processing Steps, and Modeling Methods-Example Using

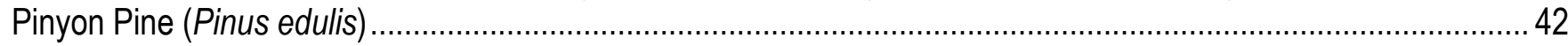

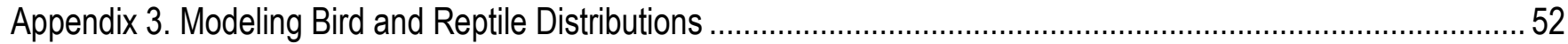

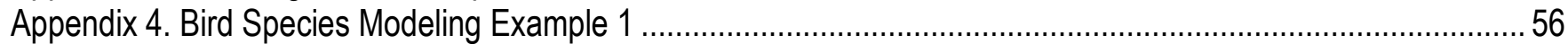

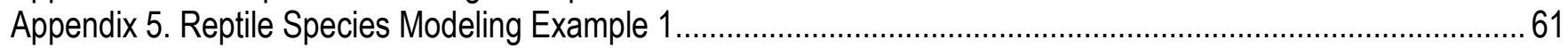

Appendix 6. Relationships between Predictor Variables and Projected Range Changes........................................6 65 


\section{Figures}

Figure 1. Map showing project area with some influential plant species identified in wildlife conceptual diagrams and used in species distribution models

Figure 2. Conceptual diagram showing order of operations, processes, data, and outcomes of our modeling........ 6 Figure 3. Boxplots showing combined contributions (explained variability) of three variable classes summed across 15 bird species distribution models (SDMs; white boxes) and 16 reptile SDMs (gray boxes), for models without vegetation $(A)$ and models containing vegetation $(B)$

Figure 4. Projected changes in range for 15 bird species between 2009 (contemporary time) and 2099 ............. 18

Figure 5. Graphs showing projected changes in range for 15 bird species (A) and 16 reptile species (B,C, differentiated by dispersal assumptions) between contemporary time (2009) and 2039 (T2039; light gray boxes), and between contemporary time and 2099 (T2099; dark gray boxes).

Figure 6. Projected changes in range for 16 reptile species between 2009 (contemporary time) and 2099 ......... 20

Figure 7. Graphs showing select correlations $(P<0.1)$ between environmental variables and magnitude of range expansions or contraction for birds (A) and reptiles (B), calculated for 2039 (light gray boxes) and 2099 (dark gray boxes).

\section{Tables}

Table 1. Selected biological attributes for 15 bird and 16 reptile species from southwestern United States that were examined in this study

Table 2. Environmental variables included in a bird and (or) reptile range-change meta-analysis ......................... 8

Table 3. Results from 15 bird species distribution models with (VEG) and without vegetation (NON-VEG) linked to a focal species.

Table 4. Results from 16 reptile species distribution models with (VEG), and without vegetation (NON-VEG) linked to a focal species. 16

Table 5. Multiple regression equations for birds that predict changes in species' ranges (2039 or 2099) using biological attributes and habitat-fragmentation metrics created from contemporary range maps 


\section{Conversion Factors}

International System of Units to Inch/Pound

\begin{tabular}{|c|c|c|}
\hline Multiply & By & To obtain \\
\hline \multicolumn{3}{|c|}{ Length } \\
\hline millimeter $(\mathrm{mm})$ & 0.03937 & inch (in.) \\
\hline meter $(\mathrm{m})$ & 3.281 & foot $(\mathrm{ft})$ \\
\hline meter $(\mathrm{m})$ & 1.094 & yard $(y d)$ \\
\hline kilometer $(\mathrm{km})$ & 0.6214 & mile (mi) \\
\hline \multicolumn{3}{|c|}{ Area } \\
\hline square kilometer $\left(\mathrm{km}^{2}\right)$ & 47.1 & acre \\
\hline square kilometer $\left(\mathrm{km}^{2}\right)$ & 0.3861 & square mile $\left(\mathrm{mi}^{2}\right)$ \\
\hline \multicolumn{3}{|c|}{ Migration rate } \\
\hline meter per year $(\mathrm{m} / \mathrm{yr})$ & 3.281 & foot per year $\mathrm{ft} / \mathrm{yr}$ ) \\
\hline \multicolumn{3}{|c|}{ Mass } \\
\hline $\operatorname{gram}(\mathrm{g})$ & 0.03527 & ounce, avoirdupois (oz) \\
\hline
\end{tabular}

Temperature in degrees Celsius $\left({ }^{\circ} \mathrm{C}\right)$ may be converted to degrees Fahrenheit $\left({ }^{\circ} \mathrm{F}\right)$ as ${ }^{\circ} \mathrm{F}=\left(1.8 \times{ }^{\circ} \mathrm{C}\right)+32$.

\section{Datums}

Vertical coordinate information is referenced to the North American Vertical Datum of 1988 (NAVD 88).

Horizontal coordinate information is referenced to the North American Datum of 1983 (NAD 83).

Altitude, as used in this report, refers to distance above the vertical datum.

\section{Abbreviations}

AIC

AKN

AR4

AUC

CMIP3

ESRI

FIA

GCM

GIS

IPCC

Maxent

NCCWSC

NMBG

PRISM

ROC

SCP

SDM

TRI

WCRP
Akaike's Information Criterion

Avian Knowledge Network

Fourth Assessment Report

Area Under the receiver operating Curve

Coupled Model Intercomparison Project phase

Environmental Systems Research Institute

Forest Inventory and Analysis

general circulation model

geographical information system

Intergovernmental Panel on Climate Change

maximum entropy modeling

National Climate Change and Wildlife Science Center

number of months on the breeding ground

Parameter-elevation Regressions on Independent Slopes Model

receiver-operating-characteristic

Southern Colorado Plateau

species distribution model

terrain ruggedness index

World Climate Research Programme 
This page intentionally left blank 


\title{
Identifying Bird and Reptile Vulnerabilities to Climate Change in the Southwestern United States
}

\author{
By James R. Hatten ${ }^{1}$, J. Tomasz Giermakowski², Jennifer A. Holmes ${ }^{3}$, Erika M. Nowak³, Matthew J. Johnson³, \\ Kirsten E. Ironside ${ }^{1}$, Charles van Riper III ${ }^{1}$, Michael Peters ${ }^{3}$, Charles Truettner ${ }^{3}$, Kenneth L. Cole ${ }^{1,3}$
}

\begin{abstract}
Current and future breeding ranges of 15 bird and 16 reptile species were modeled in the Southwestern United States. Rather than taking a broad-scale, vulnerability-assessment approach, we created a species distribution model (SDM) for each focal species incorporating climatic, landscape, and plant variables. Baseline climate (1940-2009) was characterized with Parameter-elevation Regressions on Independent Slopes Model (PRISM) data and future climate with global-circulation-model data under an A1B emission scenario. Climatic variables included monthly and seasonal temperature and precipitation; landscape variables included terrain ruggedness, soil type, and insolation; and plant variables included trees and shrubs commonly associated with a focal species. Not all speciesdistribution models contained a plant, but if they did, we included a built-in annual migration rate for more accurate plant-range projections in 2039 or 2099 . We conducted a group meta-analysis to (1) determine how influential each variable class was when averaged across all species distribution models (birds or reptiles), and (2) identify the correlation among contemporary (2009) habitat fragmentation and biological attributes and future range projections (2039 or 2099). Projected changes in bird and reptile ranges varied widely among species, with one-third of the ranges predicted to expand and twothirds predicted to contract. A group meta-analysis indicated that climatic variables were the most influential variable class when averaged across all models for both groups, followed by landscape and plant variables (birds), or plant and landscape variables (reptiles), respectively. The second part of the meta-analysis indicated that numerous contemporary habitat-fragmentation (for example, patch isolation) and biological-attribute (for example, clutch size, longevity) variables were significantly correlated with the magnitude of projected range changes for birds and reptiles. Patch isolation was a significant trans-specific driver of projected bird and reptile ranges, suggesting that strategic actions should focus on restoration and enhancement of habitat at local and regional scales to promote landscape connectivity and conservation of core areas.
\end{abstract}

\footnotetext{
${ }^{1}$ U.S. Geological Survey.

${ }^{2}$ University of New Mexico.

${ }^{3}$ Northern Arizona University.
} 


\section{Introduction}

The climate of the Southwestern United States is predicted to undergo extreme changes this century, with temperatures projected to increase by $3.5-4{ }^{\circ} \mathrm{C}$ and precipitation projected to decrease by at least 5-20 percent (Seager and others, 2007; Solomon and others, 2007; Diffenbaugh and others, 2008). Region-wide ecosystem processes and system dynamics will be especially sensitive to relatively small changes in climate in the arid and semi-arid environments (Millennium Ecosystem Assessment, 2005). The coalescing effect of these changes in an already arid region will profoundly affect the distributions and viability of plant and animal populations (Cole and others, 2011; Barrows and Murphy-Mariscal, 2012; Comer and others, 2012; Barrows and others, 2014). Furthermore, some Southwestern wildlife species that are locally abundant may be at significant risk of extinction by the end of the century if projected contractions in range prove true (Sinervo and others, 2010; van Riper and others, 2014). Given these predictions, there is a strong need for actionable science to support management decisions related to climate change and biodiversity. We defined actionable science as useful information for managers to mitigate potential changes in the range of a species that may result from climate change. Natural resource managers in the Southwestern United States are especially interested in the potential consequences of climate change so they can adapt management strategies to conserve and sustain wildlife populations and habitats (Friggens and others, 2013).

Predicting future distributions of wildlife species and identifying trans-specific drivers of range changes are needed to provide managers with empirical assessments of key factors that affect the vulnerability of species to climate change, and their future prospects, especially species of special conservation concern (Coe and others, 2012). Specifically, information is needed on the vulnerability of the region's species to climate change and the factors that affect climate change vulnerability, comprised of sensitivity (intrinsic traits that affect their ability to tolerate climatic variations), exposure (extrinsic factors that result from climate change in the area occupied by the species), adaptability (the capacity of species to cope with climate change (Dawson and others, 2011; Gardali and others, 2012; Pacifici and others, 2015) and exaptations (in the sense of Berry and others, 2002). Approaches used to identify at-risk species often use trait-based vulnerability indices that primarily estimate sensitivity, or use coarse, non-quantitative estimates of exposure to identify species most in need of conservation action and to prioritize management actions (Gardali and others, 2012). More quantitative assessments of climate change effects on species have been based mostly on climate-envelope models (Guisan and Thuiller, 2005; Dawson and others, 2011), species distribution models (SDMs) that use climate variables exclusively to project suitable climates, that are best suited for measuring exposure to climate change (Dawson and others, 2011). Predicted changes in ranges using an approach that considers multiple factors known to affect species distribution, including dominant plant species, are needed to identify those habitats most vulnerable to climate change and to aid in prioritizing conservation efforts (U.S. Fish and Wildlife Service, 2010; Rowland and others, 2011; Comer and others, 2012).

To assist managers in meeting bioclimatic challenges of this century, a novel approach was used to assess the climate-change vulnerability of select bird and reptile species of the Southwestern United States. Birds and reptiles comprise most of the vertebrate biodiversity in this region (Boykin and others, 2007), so birds and reptiles were selected as the modeling foci given their taxonomic relatedness (e.g., $\mathrm{Xu}$ and others, 2014), yet differing physiologies and ecologies. Volant, endothermic bird species may be less affected by climatic perturbations compared to relatively non-volant terrestrial ectothermic reptiles analyzed in this study (e.g., Aragón and others, 2010; Sinervo and others, 2010; Buckley and others, 2012). Birds are a comparatively well-studied group of animals, with abundant published data available on their distribution and biological attributes, whereas similar data are absent for many reptile species (Bonnet and others, 2002; van Riper and others, 2014; but see Lovich and Ennen, 2013, for desert 
tortoise). By examining responses between different taxa, we were able to evaluate a wide range of potential responses to predicted changes in climate. We developed species-specific conceptual diagrams that describe biological attributes and ecological relationships and then used downscaled general circulation models (GCMs) under an A1B emission scenario (a middle emissions pathway [Nakicenovic and Swart, 2000; Pachauri and Reisinger, 2007]) to project changes in the ranges of species (Garfin and others, 2010). Species distribution models (SDMs, often referred to as ecological niche, bioclimatic, or habitat distribution models) also were developed to estimate changes in projected ranges of focal bird and reptile species in response to projected climate change. Finally, the dynamics of range change were assessed by including in the SDMs landscape features (for example, topography and insolation) and plant species (for example, creosote bush [Larrea tridentata] and ponderosa pine [Pinus ponderosa]) identified in the conceptual diagram of each species.

The goals of this project were twofold: (1) increase the understanding of the sensitivities and vulnerabilities of each focal species to climate change, using conceptual diagrams and probability models; and (2) provide managers with actionable science based on the modeling efforts. These goals were achieved by expanding on a previous modeling effort by van Riper and others (2014), enabling us to double the number of species for modeling purposes and to conduct a group meta-analysis (Fernandez-Duque and Valeggia, 1994). Specifically, we identified trans-specific drivers that correlated with predicted range changes across each group (reptiles or birds) between contemporary time (2009) and 2039, and between contemporary time and 2099. Incorporating species-specific, habitatfragmentation metrics and biological attributes enabled the generation of important information about potential effects of climate change on future ranges and long-term survival (Sinervo and others, 2010; Bradshaw and others, 2014). By design, this approach was in direct contrast to broad-scale, multispecies vulnerability assessments developed by The Nature Conservancy and others (Friggens and

others, 2013; National Audubon Society, 2014; Young and others, 2015). The sample sizes for each group were more modest than for some projects that batch-analyze the occurrence records of species with automated techniques (e.g., Sohl, 2014; Wright and others, 2015) because specific information was incorporated on the biological attributes, ecological characteristics, and current range of each species, including their relationship to plants. To make these projections more realistic, the likely future plant migration rates were estimated using recent observations as well as paleoecological data on movements following past rapid climate changes (McLachlan and others, 2005; Cole and others, 2011, 2013).

\section{Materials and Methods}

\section{Project Area}

The focal area of the modeling centered on the Southwestern United States Arizona (western New Mexico, Utah, southwestern Colorado, southern Nevada, and southeastern California). Few bird species have breeding ranges confined to the Southwestern United States, so it also was necessary to account for potential range expansions in the model simulations. Therefore, all lands west of the 100th meridian inside the conterminous United States $\left(3,706,272 \mathrm{~km}^{2}\right)$ were included. The project area encompasses a broad range of geographic, topological, and climatic influences, within a diverse array of ecosystems, associated vegetation types, and biota. Major ecoregions include four large deserts (Sonoran, Mojave, Great Basin, and Chihuahuan); the Colorado Plateau; the Sierra Nevada Mountains, 
Rocky Mountains, and Cascade Range; the Grand Canyon; and dozens of sky-islands scattered across the West. The project area contains several dominant plant species identified in conceptual diagrams (for example, ponderosa pine, Douglas fir [Pseudotsuga menziesii], creosote bush, big sagebrush [Artemisia tridentata], and pinyon pine[Pinus edulis]) and shown in figure 1. Focal wildlife species modeled included resident and migratory birds and resident reptiles whose range (residents) or breeding range (migrants) are completely or mostly within the project area.

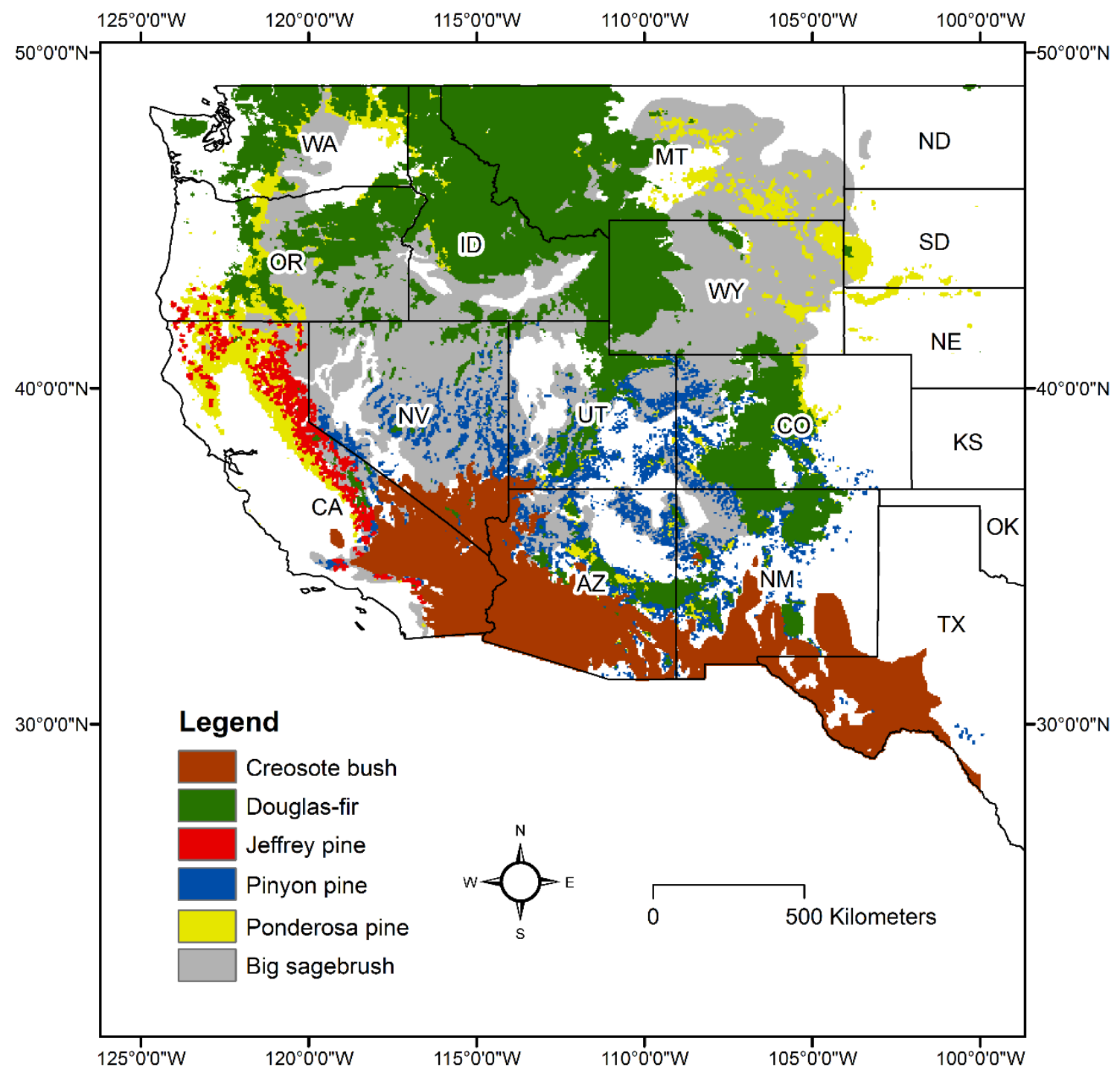

Figure 1. Map showing project area with some influential plant species identified in wildlife conceptual diagrams and used in species distribution models. Project area is bounded by the 100th meridian on the east, the Pacific Ocean on the west, the Canadian border on the north, and the Mexican border on the south. 


\section{Modeling Overview}

The results of a previous National Climate Change and Wildlife Science Center (NCCWSC) study (van Riper and others, 2014) were built by incorporating their data into a new Southwest Climate Change Science Center (SCWSC) analysis. Conceptual models were developed from literature reviews for each focal species to identify important biological attributes, articulate hypotheses, and aid in the design and interpretation of SDMs. The literature (for example, Birds of North America species accounts) and our own published and unpublished data (Nowak and others, 2016) were used to identify a suite of factors likely to affect where a species lived, died, and reproduced, along with any functional explanation. These mechanistic conceptual models were used to identify candidate variables for constructing SDMs to explain and project distributions of species. Variables that had major effects and were retained in SDMs supported the effects hypothesized in the conceptual diagrams (van Riper and others, 2014).

The modeling process implemented had six distinct steps (fig. 2):

1. With the aid of Resource Managers Advisory Group composed of Federal and State land managers, we identified and prioritized plant and animal species of interest to resource managers related to prospective climate change.

2. We used a geographical information system (GIS) to link bird and reptile distributions to plantspecies distributions, landforms, and contemporary climatic conditions.

3. We developed spatially explicit SDMs to map the current range of focal species with and without plants.

4. We evaluated and refined the SDMs with validation/test data that were withheld from model training.

5. We created future range maps for each species, with and without the incorporation of plants, using projected climate data for years 2010-39 and 2010-99.

6. We conducted a group (birds or reptiles) meta-analysis that examined two aspects of the collective modeling results - (a) the overall predictive capability of each group of predictor variables (landscape, climate, plants) that were used in the creation of contemporary SDMs, and (b) correlations among the projected range changes (2039 or 2099) and biological attributes of species, as well as climatic conditions and habitat-fragmentation patterns identified from contemporary SDMs and range maps.

Identifying trans-specific drivers of range change within and between endotherms and ectotherms should be of value to management agencies in identifying species most vulnerable to climate change and in developing wildlife action plans designed to minimize its harmful effects. 


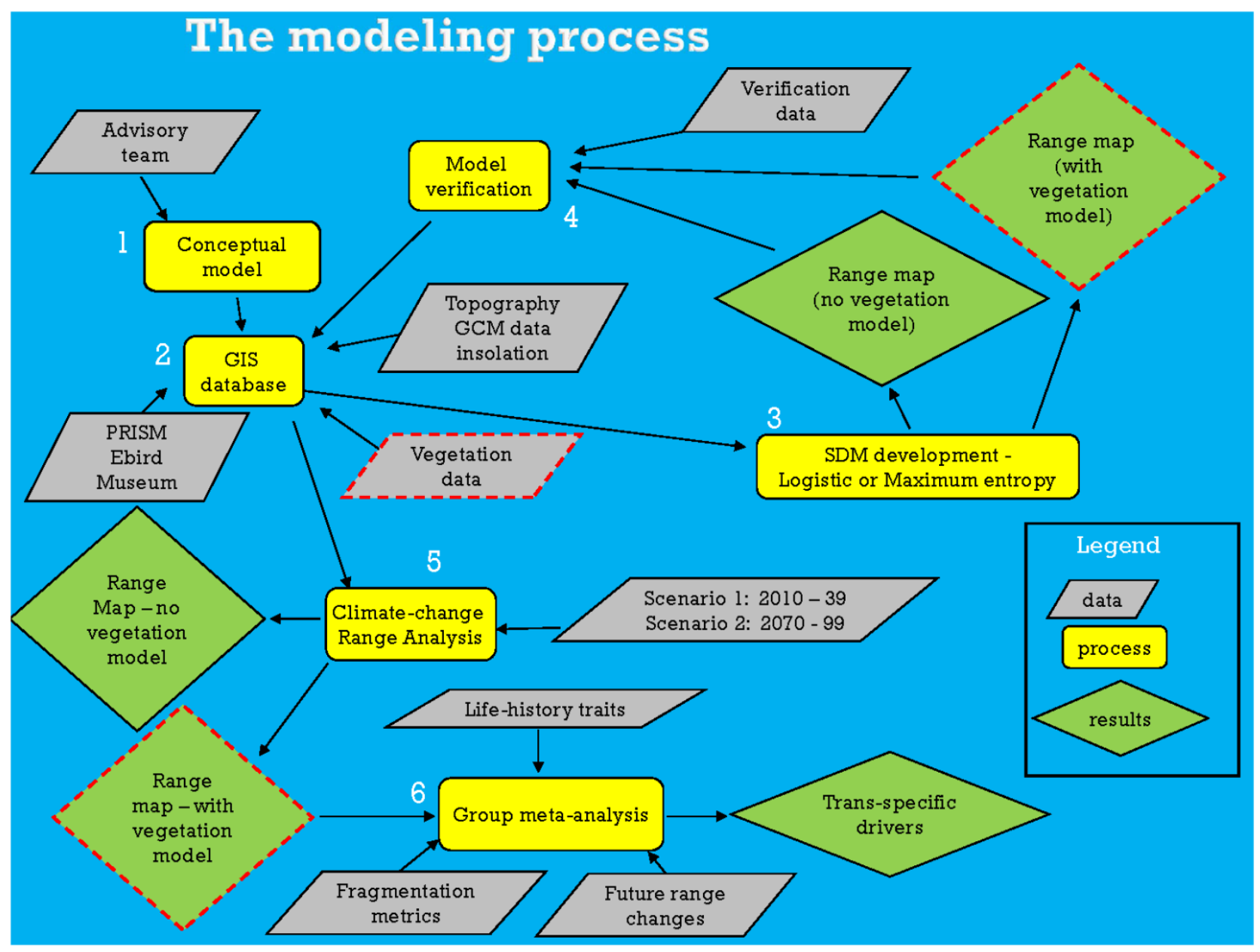

Figure 2. Conceptual diagram showing order of operations, processes, data, and outcomes of our modeling.

\section{Selection of Focal Species}

Focal species were selected based on several sources of information, including input from a Resource Managers Advisory Group that included wildlife and conservation partners. A species was considered for modeling if it met the following criteria:

1. Its breeding (migrant birds) or year-round (resident birds and reptiles) range is largely within the interior western United States,

2. It is present within a substantial part of the project area,

3. Sufficient information about its ecology is available,

4. It is not extirpated from a substantial part of its range,

5. Adequate locations showing its distribution are available,

6. Predictor variables (as denoted in the conceptual diagrams) are available in a spatially explicit format, and

7. It fits into a specific functional group (for example, long- and short-lived species, predators compared to herbivores). 
Each species was ranked for modeling suitability by assigning a score of 1 to 3 to each criterion and summed to obtain a final individual rank (van Riper and others, 2014). The ranked list was used to select 15 bird and 16 upland reptile species representing a broad range of life histories, including herbivores and predators, long-lived and short-lived, and habitat specialists and generalists (table 1), building on the species selected in earlier efforts by van Riper and others (2014).

Table 1. Selected biological attributes for 15 bird and 16 reptile species from southwestern United States that were examined in this study.

[Abbreviations of species common names used in the text, average clutch size, average adult body size, and taxon-specific categories are given. Adult body size is given as mass (in grams) for birds and as snout-vent-length (SVL, in millimeters) for female reptiles. Number of months on the breeding ground and nest type (open cup or cavity nester) are given for birds]. NA stands for unknown.

\begin{tabular}{|c|c|c|c|c|c|c|c|c|c|}
\hline \multirow[b]{2}{*}{$\begin{array}{l}\text { Abbreviated } \\
\text { common } \\
\text { name }\end{array}$} & \multirow[b]{2}{*}{ Common name } & \multirow[b]{2}{*}{ Scientific name } & \multicolumn{7}{|c|}{ Biological attributes } \\
\hline & & & Clutch size & \multicolumn{2}{|c|}{$\begin{array}{l}\text { Body mass } \\
\text { (grams) }\end{array}$} & \multicolumn{2}{|c|}{$\begin{array}{c}\text { Lifespan } \\
\text { (Longevity, in } \\
\text { years) }\end{array}$} & $\begin{array}{c}\text { Number of } \\
\text { months on } \\
\text { breeding } \\
\text { ground } \\
\text { (Birds) }\end{array}$ & $\begin{array}{l}\text { Nest type } \\
\text { (Birds) }\end{array}$ \\
\hline \multicolumn{10}{|c|}{ Birds } \\
\hline BTGW & $\begin{array}{l}\text { Black-throated gray } \\
\text { warbler }\end{array}$ & Setophaga nigrescens & 4.00 & \multicolumn{2}{|c|}{7.90} & \multicolumn{2}{|l|}{ NA } & 3.00 & cup \\
\hline BTSP & Black-throated sparrow & Amphispiza bilineata & 3.00 & \multicolumn{2}{|c|}{13.20} & \multicolumn{2}{|l|}{ NA } & 5.50 & cup \\
\hline BRSP & Brewer's sparrow & Spizella breweri & 3.00 & \multicolumn{2}{|c|}{10.80} & \multicolumn{2}{|l|}{$\mathrm{NA}$} & 2.50 & cup \\
\hline FLOW & Flammulated owl & Psiloscops flammeolus & 3.00 & 55. & & NA & & & cavity \\
\hline GRFL & Gray flycatcher & Empidonax wrightii & 4.00 & 12. & & NA & & & cup \\
\hline GRVI & Gray vireo & Vireo vicinior & 3.00 & 12. & & NA & & & cup \\
\hline JUTI & Juniper titmouse & Baeolophus ridgwayi & 6.00 & 16. & & NA & & & cavity \\
\hline LETH & Le Conte's thrasher & Toxostoma lecontei & 3.00 & 61. & & NA & & & cup \\
\hline PIJA & Pinyon jay & $\begin{array}{l}\text { Gymnorhinus } \\
\text { cyanocephalus }\end{array}$ & 4.00 & 105. & & NA & & & cup \\
\hline PYNU & Pygmy nuthatch & Sitta pygmaea & 7.00 & 10. & & NA & & & cavity \\
\hline RNSA & Red-naped sapsucker & Sphyrapicus nuchalis & 5.00 & 49. & & NA & & & cavity \\
\hline SASP & Sagebrush sparrow & $\begin{array}{l}\text { Artemisiospiza } \\
\text { nevadensis }\end{array}$ & 3.00 & 18. & & NA & & & cup \\
\hline SATH & Sage thrasher & Oreoscoptes montanus & 4.00 & 43. & & NA & & & cup \\
\hline VIWA & Virginia's warbler & Oreothlypis virginiae & 4.00 & 8. & & NA & & & cup \\
\hline WISA & Williamson's sapsucker & Sphyrapicus thyroideus & 5.00 & 47. & & NA & & & cavity \\
\hline & & & & & & Biolc & ical & ibutes & \\
\hline $\begin{array}{c}\text { Abbreviated } \\
\text { common name }\end{array}$ & Common name & Latin name & & $\begin{array}{l}\text { Clutch size } \\
\text { (median) }\end{array}$ & & $\begin{array}{l}\text { le SVL } \\
\text { meters) }\end{array}$ & $\begin{array}{l}\text { Liff } \\
\text { (Lon } \\
\text { in }\end{array}$ & $\begin{array}{l}\text { pan } \\
\text { evity, } \\
\text { ars) }\end{array}$ & rophic niche \\
\hline & & & eptiles & & & & & & \\
\hline AREL & Glossy snake & Arizona elegans & & 8.5 & & 000 & & 20 & Predator \\
\hline ASFL & Gila spotted whiptail & Aspidoscelis flagellicau & & 4.0 & & 85 & & 4 & Predator \\
\hline ASNE & New Mexico whiptail & Aspidoscelis neomexica & & 2.0 & & 82 & & 4 & Predator \\
\hline ASTI & Tiger whiptail & Aspidoscelis tigris & & 4.0 & & 76 & & 8 & Predator \\
\hline ASVE & Plateau striped whiptail & Aspidoscelis velox & & 4.0 & & 75 & & & Predator \\
\hline CRCE & Arizona black rattlesnake & Crotalus cerberus & & 4.9 & & 614.9 & & 20 & Predator \\
\hline CRLE & Rock rattlesnake & Crotalus lepidus & & 3.6 & & 482.5 & & 23 & Predator \\
\hline DIDO & Desert iguana & Dipsosaurus dorsalis & & NA & & NA & & 10 & Herbivore \\
\hline ELKI & Madrean alligator lizard & Elgaria kingii & & NA & & NA & & 20 & Predator \\
\hline GOMO & Morafka's desert tortoise & Gopherus morafkai & & 5.0 & & 287 & & 50 & Herbivore \\
\hline HESU & Gila monster & Heloderma suspectum & & 5.7 & & 360 & & 24 & Predator \\
\hline HOMA & Common lesser earless lizard & Holbrookia maculata & & NA & & NA & & 4 & Predator \\
\hline PHHE & Greater short-horned lizard & Phrynosoma hernandes & & 16 & & 65 & & 6 & Predator \\
\hline SAAT & Chuckwalla & Sauromalus ater & & 7.0 & & 140 & & 35 & Herbivore \\
\hline SCGR & Sagebrush lizard & Sceloporus graciosus & & 5.0 & & & & 7 & Predator \\
\hline TEOR & Ornate box turtle & Terrapene ornata & & 3.6 & & 154 & & 22.5 & Omnivore \\
\hline
\end{tabular}




\section{Environmental (GIS) Database}

We selected candidate predictor variables that were identified in conceptual diagrams, and that could be rendered as spatially explicit covariates and covered the entire Western United States (table 2). Landscape variables included terrain ruggedness index (TRI), insolation (May), geology (substrate category, age), and soils (depth to lithic layer, depth to restrictive layer, drainage, composition). Plant species included species of coniferous and deciduous trees, shrubs, and grasses important to our focal species (van Riper and others, 2014). Climate data were the monthly, seasonal, and species-specific breeding season precipitation and temperature variables (Daly and others, 1994).

Table 2. Environmental variables included in a bird and (or) reptile range-change meta-analysis.

[T2039 and T2099 are range change (expansion/contraction) variables characterizing baselines through 2039 (T2039) and 2099 (T2099), respectively. Some fragmentation metrics have derivatives: Mean (MN), area-weighted mean (AM), range (RA), standard deviation (SD), and coefficient of variation (CV). Fragmentation metrics AI, ED, LSI, and LPI have no derivatives. Climatic variables can also be described in text by a range of months using the following syntax: PPTAVG_4-8 (average precipitation for April-August), or TMPMAX_6-8 (maximum monthly temperature June-August)]

\begin{tabular}{|c|c|c|}
\hline CLASS & Variable abbreviation & Description \\
\hline \multirow[t]{2}{*}{ RANGE CHANGE } & T2039 & $\begin{array}{l}\text { Range expansion or contraction (percent) between baseline and } \\
2039\end{array}$ \\
\hline & T2099 & $\begin{array}{l}\text { Range expansion or contraction (percent) between baseline and } \\
2099\end{array}$ \\
\hline \multirow[t]{4}{*}{ LIFE HISTORY } & NMBG & Number of months on the breeding ground \\
\hline & CLUTCHSIZE & Clutch size \\
\hline & BODYMASS & Body mass (grams) \\
\hline & LONGEVITY & Known lifespan in years \\
\hline \multirow[t]{3}{*}{ LANDSCAPE } & TRI & Terrain ruggedness index \\
\hline & SOLAR_MAY & Insolation on May 1 \\
\hline & SOILS & Soil characteristics (substrate category, age) \\
\hline \multirow[t]{8}{*}{ FRAGMENTATION } & LSI & Landscape shape index \\
\hline & LPI & Largest patch index \\
\hline & AREA & Mean patch size (MN, AM, RA, SD, CV) \\
\hline & SHAPE & Shape index (MN, AM, RA, SD, CV) \\
\hline & CONTIG & Contiguity index (MN, AM, RA, SD, CV) \\
\hline & ENN & Euclidean nearest neighbor (MN, AM, RA, SD, CV) \\
\hline & AI & Aggregation index \\
\hline & ED & Edge density \\
\hline \multirow[t]{6}{*}{ CLIMATE } & PPTAVG & $\begin{array}{l}\text { Average precipitation (F [Fall], P [Spring], S [Summer], W } \\
\text { [Winter]) }\end{array}$ \\
\hline & PРТМAX & $\begin{array}{l}\text { Maximum precipitation (F [Fall], P [Spring], S [Summer], W } \\
\text { [Winter]) }\end{array}$ \\
\hline & PPTMIN & $\begin{array}{l}\text { Minimum precipitation (F [Fall], P [Spring], S [Summer], W } \\
\text { [Winter]) }\end{array}$ \\
\hline & TMPAVG & $\begin{array}{l}\text { Average fall temperature (F [Fall], P [Spring], S [Summer], W } \\
\text { [Winter]) }\end{array}$ \\
\hline & TMPMAX & $\begin{array}{l}\text { Maximum temperature (F [Fall], P [Spring], S [Summer], W } \\
\text { [Winter]) }\end{array}$ \\
\hline & TMPMIN & $\begin{array}{l}\text { Minimum fall temperature (F [Fall], P [Spring], S [Summer], W } \\
\text { [Winter]) }\end{array}$ \\
\hline
\end{tabular}


For purposes of these analyses, a species was considered present if there was a single record within a $16-\mathrm{km}^{2}(4 \times 4-\mathrm{kilometer})$ cell. Two types of bird location data were acquired-(1) presence only, and (2) presence and absence data from the Avian Knowledge Network eBird database (Iliff and others, 2009; Sullivan and others, 2009), and processed data as described in van Riper and others (2014), with most records obtained after 1970. Most reptile records were obtained from the HerpNET and Global Biodiversity Information Facility (GBIF) data portals, and the National Park Service Inventory and Monitoring Network databases (Northern Colorado Plateau, Southern Colorado Plateau, Sonoran, Chihuahuan, and Mojave; Persons and Nowak, 2006a, 2006b, 2007; Persons and others, 2006). Compared to bird locations, reptile locations were more evenly distributed temporally, dating back to 1940. Bird observations were truncated at 1990 and reptile observations at 1950. These cutoff dates were selected for contemporary data to maximize the amount of data available; in particular, reptile observations are scarcer than bird observations, so we used a much longer time period for them. To account for the lag time between shifting climate and species distributions, we incorporated a 10year buffer (for example, leading edge) between climatic conditions and bird and reptile observations, averaging climate for 1980-2009 for bird models, and for 1940-2009 for reptile models.

In addition to variables carried over from the NCCWSC project (van Riper and others, 2014), two new sets of variables were developed to conduct a group meta-analysis. Biological attributes for birds or reptiles were summarized, including mass (weight), clutch or litter size, number of months on the breeding grounds (for birds, as a measure of migratory propensity), longevity (reptiles), and nest type (birds). These data were tabular, not spatially explicit, and were obtained through a review of the literature and(or) our own data. We also calculated fragmentation metrics, which were both tabular and spatially explicit, obtained through a GIS-based analysis of range maps produced from contemporary SDMs. Additional information about bird and reptile distribution data and processing steps are available in appendix 1.

\section{Contemporary and Projected Climates}

We obtained climate data for the contemporary period (reptiles, 1940-2009; birds, 1980-2009) from the PRISM (Parameter-elevation Regressions on Independent Slopes Model) climate dataset (Daly and others, 1994). The PRISM average maximum and minimum monthly temperatures were averaged together to calculate monthly means that corresponded with the mean monthly temperatures provided in the Intergovernmental Panel on Climate Change (IPCC) Fourth Assessment Report (AR4) GCM simulation results. We obtained IPCC AR4 GCM results from the World Climate Research Programme (WCRP) Coupled Model Intercomparison Project phase 3 (CMIP3) multi-model dataset (Meehl and others, 2007; Solomon and others, 2007). We used five climate projections or Global Circulation Models (GCMs; that is, ukmo_hadgem1, mpi_echam5, cnrm_cm3, csiro_mk3, and ncar_ccsm3) and a 22-model GCM ensemble that were obtained from the IPCC Fourth Assessment Report model archive (Solomon and others, 2007). 
These 5 individual GCMs and the 22-model GCM ensemble were statistically downscaled to 4$\mathrm{km}$ resolution for the Southern Colorado Plateau and the conterminous Western United States (Garfin and others, 2010). The five individual GCMs were selected based on their ability to successfully hindcast 20th-century climate, especially the precipitation seasonality that is critical for ecosystems in the Four Corners Region of the Southern Colorado Plateau (SCP; $35^{\circ}-38^{\circ} \mathrm{N}, 114^{\circ}-107^{\circ} \mathrm{W}$ ). Instead of the four classical calendar seasons, the Southern Colorado Plateau and Sonoran Desert regions are shaped by the climates in the distinctive seasons of: winter-spring (November-March), arid foresummer (May-June), and monsoon (July-September). Collectively, the five GCMs predict that annual temperatures in the region will increase $1.5--3.6^{\circ} \mathrm{C}$ by mid-century, and $2.5-5.4{ }^{\circ} \mathrm{C}$ by century end, with annual temperatures projected to exceed the 1950-1999 range of variability by the 2030s. There is greater uncertainty surrounding precipitation forecasts, with the 22-model ensemble average predicting that SCP annual precipitation may decrease by 6 percent by century end, with May-June precipitation declining by 11-45 percent (Garfin and others, 2010). We used the five GCMs, and the 22-model GCM ensemble, to project plant and animal species distributions because they encompassed the spectrum of plausible future climates in the study area.

\section{Species Distribution Models}

Birds and reptiles required different modeling approaches because of differences in collection methods and presence records for each group. For birds, we used binary logistic regression (Hosmer and Lemeshow, 1989) to identify important environmental variables because we obtained binary, presenceabsence data, from ebird (Keating and Cherry, 2004). We used Arc/Info ${ }^{\circledR}$ GRID (Environmental Systems Research Institute, 1992) to calculate and map the probability that a bird species would be present within each 4-km cell. In contrast, for reptiles, we used maximum entropy modeling (Maxent; Elith and others, 2010) because it is useful for evaluating relationships between predictor variables and reptile ranges as most reptile records are based on museum records that are presence-only data. We used Maxent (Phillips and others, 2006; Phillips and Dudík, 2008) to calculate and map the probability that a reptile species would be present because of the built-in functions of Maxent for random seeds, background selection, cross-validation, and model averaging (Phillips and Dudík, 2008).

We incorporated plant distributions in our predictive modeling whenever a conceptual diagram identified a plant as ecologically important to a focal species (for example, pinyon pine is a critical food source for pinyon jay, Gymnorhinus cyanocephalus). Some of the plant species we selected had already been modeled, and their ranges projected into the future (Cole and others, 2008; Garfin and others, 2010); ranges of other plant species were modeled specifically for this project using the same methods (see appendix 2). Importantly, an annual migration rate was included in future range projections of each plant species using a migration constraint of $50 \mathrm{~m} / \mathrm{yr}$ for long-lived dominant species, and a rate of 500 $\mathrm{m} / \mathrm{yr}$ for early successional species (van Riper and others, 2014). We used distribution data for particular plant species over vegetation or land-cover types because studies have shown that plant assemblages only exist at certain times and places. This is especially apparent in paleoecological studies showing vegetation shifts following major climate changes (Davis, 1981; Cole, 1985). As the multivariate envelope of climate variables rearranges through either time or space, individual plant species have unique responses, usually causing the dominant species of what was thought to be a stable plant association to shift individualistically, leading to different associations. As a result, if a specific dominant plant species is a major determinant of a bird's distribution, then it follows that modeling that particular plant species should produce superior results to modeling an association that may soon become disaggregated and lose that species. Additional information about our modeling approach and methodologies is available in appendix 3. 


\section{Projecting Climate Effects on Species Range}

We projected future ranges of each focal species in 2039 or 2099 in five steps:

1. We populated SDM of each species with six GCM simulations of future climate (five individual models and one ensemble model), producing six range maps that had continuous probabilities for any location (0-99 percent).

2. We reclassified each range map into binary format, so a given location $(4 \times 4-\mathrm{km}$ cell $)$ was considered suitable or unsuitable range after finding the best probability threshold that maximized sensitivity and specificity (for example, 0.5).

3. We overlaid and averaged the six binary range maps with GIS, so each cell had a value from 0 to 6. A cell value of 0 meant that none of the range maps predicted range for that location, whereas a value of 6 indicated that all SDMs predicted range for that location.

4. We identified all cells where at least five of the six range maps agreed that a location was range (that is, greater than or equal to 83-percent agreement) and created a composite range map.

5. We identified changes in range between 2009 and 2039, and between 2009 and 2099, through grid subtraction (differencing) of the two binary range maps.

The resulting range maps show areas where contemporary range persisted or was lost, or where new range formed. We dealt with uncertainty when modeling future range by selecting the most accurate subset of GCMs when hind-casting Southwest climate (Garfin and others, 2010), and by setting a high (83 percent) agreement threshold (van Riper and others, 2014).

The modeling efforts indicated that a low agreement threshold increases future range and model uncertainty (because fewer SDMs need to converge), which effectively decreases the magnitude of change between contemporary time (2009) and 2039, or 2099. Conversely, a high agreement threshold decreases future range and model uncertainty (because fewer areas will be predicted suitable), which effectively increases the magnitude of projected change between contemporary time (2009) and 2039, or 2099. We cannot know for certain if an individual GCM-based SDM correctly projects future range, so we selected a high agreement threshold that lowered uncertainty and increased confidence in our predictions.

Because individual ectotherms typically have small activity areas and do not voluntarily disperse across long distances, the contrasting assumptions of having potential for dispersal, or no potential for dispersal, play a crucial role in projection of future ranges of reptiles (Araújo and others, 2006). This assumption is in contrast to birds, for which comparative dispersal capacity is relatively unlimited (Aragón and others, 2010). Although for birds we assumed unlimited dispersal; for reptiles we focused all of our analyses on a conservative assumption of no dispersal (but see Bateman and others, 2013) but calculated changes in range for both extremes of unlimited and no dispersal. A detailed example of the modeling process for the juniper titmouse (Baeolophus ridgwayi) is provided in appendix 4, and for the sagebrush lizard (Sceloporus graciosus) is provided in appendix 5. 


\section{Group Meta-Analysis}

The meta-analysis had two objectives in order to identify trans-specific drivers affecting future range projections of birds $(n=15)$ and reptiles $(n=16)$. The first objective was to identify the combined contributions (that is, explanatory power) of each class of variables (that is, temperature, precipitation, landscape), averaged across all SDMs, within each group. The second objective was to determine if habitat fragmentation, biological attributes, and climatic conditions occurring under contemporary times could explain the pattern of range for each group in 2039 or 2099. Accomplishment of objective one was straightforward; the chi-squared values for each variable were averaged, obtained through backward stepping and logistic regression during SDM development, across all SDMs. For example, if landscape variables accounted for 10 percent of the explained variability in each bird SDM, then its combined explanatory power for the bird group was 10 percent. Similarly, if climate accounted for 20 percent of explained variability in each reptile SDM, then it had a combined explanatory power of 20 percent for reptiles. The second objective was accomplished through correlation and regression analyses. Specifically, we examined the correlations between predicted range changes (2039 and 2099) for each group, contemporary climatic conditions, biological attributes, and habitat fragmentation (obtained from contemporary range maps). We used Spearman sign-rank test for correlation analysis and plotted the shape of the relations with linear and nonlinear regression (Zar, 1984). Finally, a twoindependent-sample t-test was used to assess differences in range change between bird species that nest in cavities and those that build cup nests. Accomplishing the second objective required that we first characterize the fragmentation of contemporary range for each focal species, which we calculated with Fragstats (McGarigal and Marks, 1995; McGarigal and Cushman, 2002). Fragmentation metrics obtained from contemporary range maps for each species included patch size, distance between patches, complexity of patch perimeters, variability in patch size, and aggregation (table 2).

\section{Results}

\section{Species Distribution Models}

\section{Birds}

Each bird SDM contained between 5 and 12 parameters (table 3), with pygmy nuthatch (Sitta pygmaea) containing the most parameters (12) and Le Conte's thrasher (Toxostoma lecontei) the fewest (5). When examining models that did not include plant species ("non-plant" models), temperature or precipitation variables were the most influential predictors in 73 percent of SDMs, with breeding season climate being the most influential variable in 47 percent of SDMs. Temperature variables were the most influential predictor in 27 percent of these SDMs, and precipitation (various seasons) in 40 percent (table 3; fig. 3A). Terrain ruggedness was the most influential predictor in three (20 percent) non-plant SDMs, and insolation (May 1) was the most important predictor in one (7 percent) SDM (juniper titmouse [Baeolophus ridgwayi]; fig. 3A). These patterns were altered somewhat when plants were in SDMs, but 60 percent of the most influential variables in non-plant SDMs remained the top variable in plant-based SDMs. Fourteen of the 15 bird SDMs contained at least one plant species; black-throated gray warbler (Setophaga nigrescens) did not have a close association with a particular plant species and, thus, no plant species was identified in its conceptual diagram and no plants were used as candidate variables. Although 14 bird SDMs contained at least one plant species, only juniper titmouse had a plant species as its most important variable (table 3). 
Table 3. Results from 15 bird species distribution models with (VEG) and without vegetation (NON-VEG) linked to a focal species.

[Columns show focal species (SP; abbreviations for species explained in table 1), number of parameters in each species distribution model (SDM), classification accuracy (receiver-operating-characteristic [ROC] curves), plant effects on contemporary (T2009 for year 2009) and projected range (T2039 and T2099 for years 2009-2039 and 2009-2099, respectively; percentage change), best variable (most influential) in SDM, and changes in range between contemporary time (2009) and 2039 or 2099. Abbreviations for variables are described in table 2]. NA denotes that plants were not incorporated into the SDM; JUOS is Juniperus osteosperma (see fig. 4.3).

\begin{tabular}{|c|c|c|c|c|c|c|c|c|c|c|c|c|c|}
\hline \multirow[t]{2}{*}{ SP } & \multicolumn{2}{|c|}{$\begin{array}{l}\text { Number of } \\
\text { parameters }\end{array}$} & \multicolumn{2}{|c|}{ ROC } & \multicolumn{3}{|c|}{$\begin{array}{c}\text { Effect of vegetation on } \\
\text { projected range } \\
\text { (percentage change) }\end{array}$} & \multicolumn{2}{|c|}{ Best variable in SDM } & \multicolumn{2}{|c|}{$\begin{array}{l}\text { Range change } \\
\text { NON-VEG }\end{array}$} & \multicolumn{2}{|c|}{$\begin{array}{c}\text { Range change } \\
\text { VEG }\end{array}$} \\
\hline & $\begin{array}{l}\text { NON- } \\
\text { VEG }\end{array}$ & VEG & $\begin{array}{l}\text { NON- } \\
\text { VEG }\end{array}$ & VEG & T2009 & T2039 & T2099 & NON-PLANT & PLANT & T2039 & T2099 & T2039 & T2099 \\
\hline BRSP & 9 & 10 & 0.79 & 0.80 & -5.65 & -22.06 & -30.24 & PPTAVG_5-8 & TMPAVG_P & 2.21 & -43.68 & -15.56 & -58.36 \\
\hline BTGW & 8 & NA & 0.75 & NA & NA & NA & NA & TMPMAX_5-7 & NA & -4.76 & 10.56 & NA & NA \\
\hline BTSP & 6 & 7 & 0.836 & 0.838 & -5.41 & -8.44 & -13.31 & TRI & PPTAVG_P & 8.76 & 46.62 & 5.27 & 34.38 \\
\hline FLOW & 6 & 7 & 0.774 & 0.786 & -14.86 & -27.77 & -26.96 & TMPAVG_5-8 & TMPAVG_5-8 & -7.76 & -26.23 & -21.74 & -36.71 \\
\hline GRFL & 9 & 10 & 0.728 & 0.731 & -3.43 & -2.14 & -4.43 & PPTAVG_5-8 & TMPMIN_W & -14.42 & -33.41 & -13.27 & -34.09 \\
\hline GRVI & 7 & 8 & 0.73 & 0.75 & 2.74 & -8.19 & -4.54 & TMPMAX_4-8 & TMPMAX_4-8 & 10.75 & 71.27 & -1.04 & 58.17 \\
\hline JUTI & 8 & 9 & 0.75 & 0.81 & -17.99 & -39.12 & -40.89 & SOLAR_5 & JUOS & 3.66 & 24.49 & -23.05 & -10.26 \\
\hline LETH & 5 & 6 & 0.78 & 0.81 & -15.71 & -11.37 & -45.12 & PPTAVG_S & PPTAVG_S & -39.76 & -3.8 & -36.66 & -37.37 \\
\hline PIJA & 9 & 10 & 0.79 & 0.8 & -19.4 & -22.64 & -26.36 & MAXTMP_5-9 & PPTAVG_W & -9.71 & -24.73 & -13.34 & -31.23 \\
\hline PYNU & 11 & 12 & 0.849 & 0.856 & -15.74 & -29.45 & -33.5 & PPTAVG_F & PPTAVG_F & -41.47 & -75.43 & -50.99 & -80.62 \\
\hline RNSA & 11 & 12 & 0.80 & 0.81 & -13.39 & -21.01 & -64.10 & TRI & TRI & -48.61 & -79.65 & -53.13 & -85.04 \\
\hline SASP & 9 & 10 & 0.78 & 0.79 & 10.49 & -18.86 & -22.24 & PPTAVG_4-8 & PPTAVG_4-8 & 73.66 & 68.37 & 27.52 & 18.49 \\
\hline SATH & 7 & 8 & 0.79 & 0.80 & -4.54 & -16.78 & -13.42 & PPTAVG_W & PPTAVG_W & -25.48 & -78.48 & -35.04 & -80.48 \\
\hline VIWA & 9 & 10 & 0.761 & 0.779 & 1.49 & 0.33 & 3.89 & TRI & TRI & -2.58 & -1.63 & -3.69 & -6.84 \\
\hline WISA & 9 & 10 & 0.85 & 0.87 & -7.02 & 1.78 & -2.03 & TMPAVG_4-7 & TMPAVG_4-7 & -31.50 & -73.31 & -43.69 & -78.14 \\
\hline
\end{tabular}




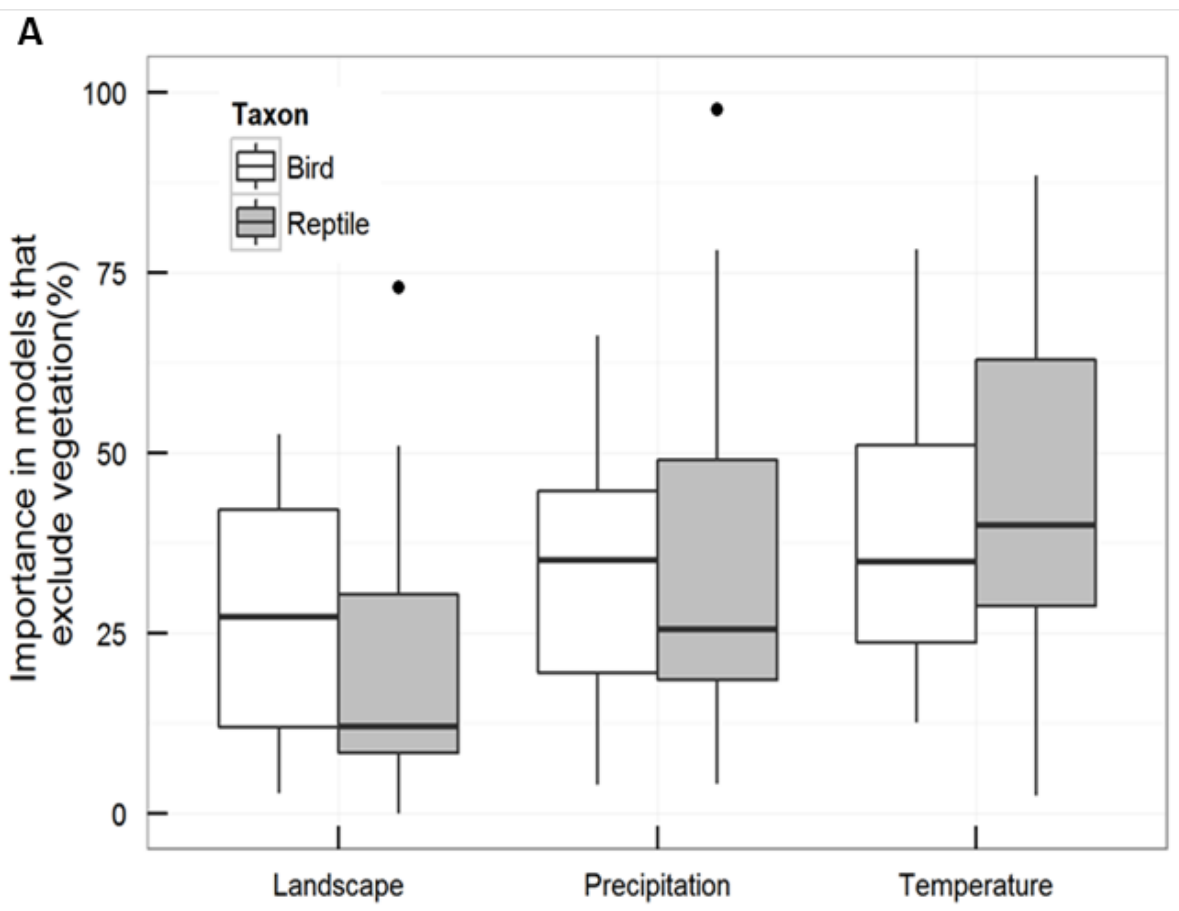

B

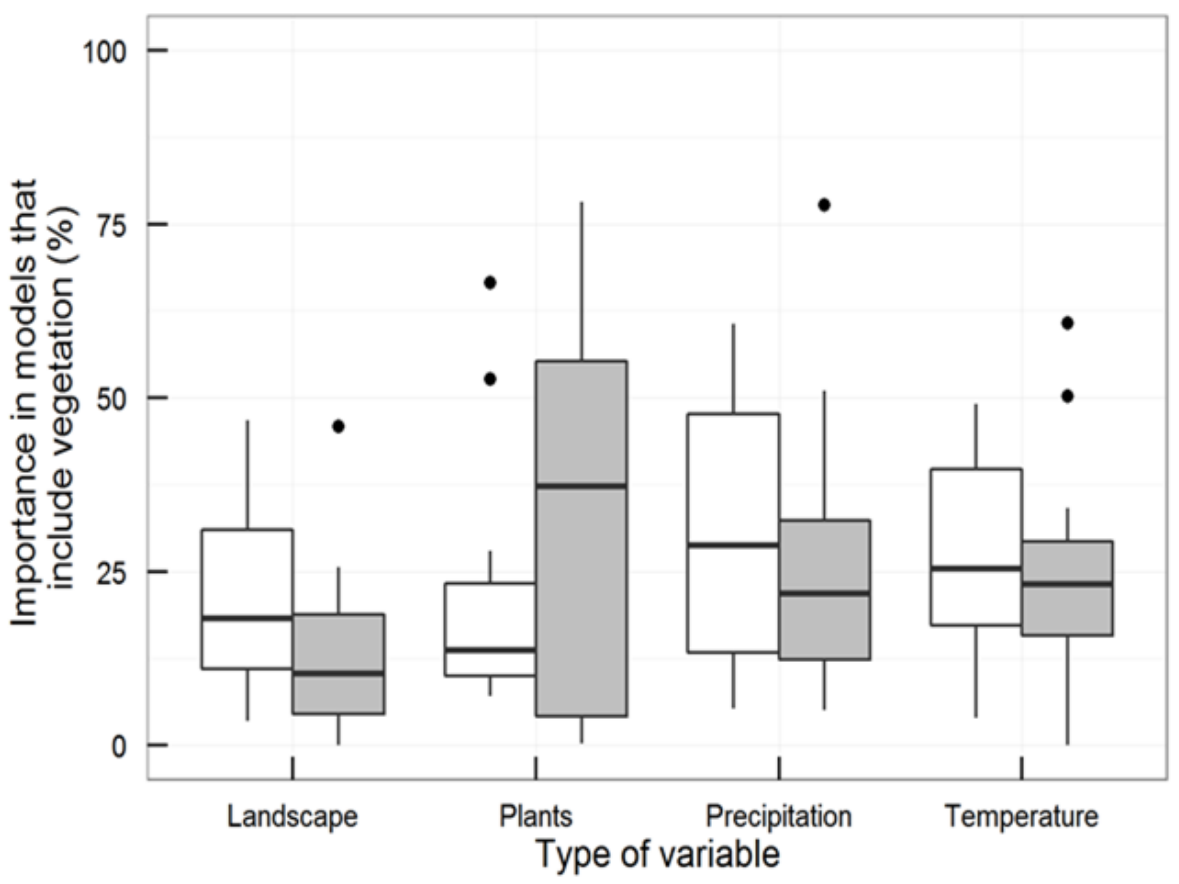

Figure 3. Boxplots showing combined contributions (explained variability) of three variable classes summed across 15 bird species distribution models (SDMs; white boxes) and 16 reptile SDMs (gray boxes), for models without vegetation $(A)$ and models containing vegetation $(B)$. The Landscape class contained the contributions of terrain ruggedness, insolation, and soils. Boxplots display the 25th and 75th percentiles (bottom and top of box), medians (interior horizontal line), 5th and 95th percentiles (bottom and top lines outside box), and outliers (dots). 
Classification accuracies for birds varied by SDM, with Williamson's sapsucker (Sphyrapicus thyroideus) achieving the highest accuracy on test data (Area Under the receiver operating Curve [AUC] $=0.87)$ and gray flycatcher (Empidonax wrightii) the least accuracy $(\mathrm{AUC}=0.73)$. In all cases, SDMs that contained a plant species achieved slightly higher ROC (receiver-operating-characteristic) curve scores (classification accuracy) than those without a plant species (mean $=5$ percent increase), with the exception of black-throated gray warbler, which contained no plant. Including plants in the models reduced predicted extents of distribution on average by 6.4 percent under contemporary conditions. The three bird SDMs where classification was most affected by a plant species, as measured by ROC, were juniper titmouse, Le Conte's thrasher, and Williamson's sapsucker, respectively.

\section{Reptiles}

Each reptile SDM contained between 2 and 12 model parameters, depending on whether plants were included in the model (table 4). Models for reptiles contained 3-11 parameters when no plants were considered, with Morafka's desert tortoise (Gopherus morafkai; Murphy and others, 2011) and Common chuckwalla (Sauromalus ater) having the fewest parameters (3) and ornate box turtle (Terrapene ornata) and glossy snake (Arizona elegans) the most parameters (11). When plant species were included in the models, the Common chuckwalla (Sauromalus ater) SDM included the fewest parameters (2) and New Mexico whiptail (Aspidoscelis neomexicana) the most (12). When examining models that did not include plant species, similar to birds, temperature or precipitation variables were the most influential predictors in 75 percent of SDMs, with winter temperatures being the most important variable in 67 percent of SDMs, followed by insolation (25 percent of SDMs; table 4; fig. $3 B$ ). The amount of insolation was the most important predictor variable in non-plant SDMs for four species (New Mexico whiptail, Plateau striped whiptail [Aspidoscelis velox], Greater short-horned lizard [Phrynosoma hernandesi] and rock rattlesnake [Crotalus lepidus]), whereas precipitation and temperature were the most important variables for the remaining 12 species. Of the 11 reptile species for which vegetation was identified in conceptual models as important, plants were the most influential variables in eight models (table 4).

Classification accuracies for reptile SDMs, measured as AUC in Maxent (see section, "Materials and Methods"), ranged from 0.89 (sagebrush lizard) to 0.995 (Madrean alligator lizard [Elgaria kingie]). In contrast to birds, the classification accuracy of models that included plant species was not statistically distinguishable from models that only relied on climate and static features of the landscape; the ROC scores were only 1 percent better for SDMs that did not include plant species. However, plant-based SDMs reduced predicted extents of distribution on average by 6.4 percent under contemporary conditions. The reptile SDMs for which classification was most affected when plants were included, as measured by ROC, were Plateau striped whiptail, Morafka's desert tortoise and desert iguana (Dipsosaurus dorsalis). 
Table 4. Results from 16 reptile species distribution models with (VEG), and without vegetation (NON-VEG) linked to a focal species.

[Columns show focal species (SP; abbreviations for species explained in table 1), number of parameters in each species distribution model (SDM), classification accuracy (receiver-operating-characteristic [ROC] curves), plant effects on contemporary (T2009 for year 2009) and projected range (T2039 and T2099 for years 2009-2039 and 2009-2099, respectively; percentage change), best variable (most influential) in SDM, and changes in range between contemporary time (2009) and 2039 or 2099. Acronyms for variables are described in table 2]. NA denotes that plants were not incorporated into the SDM.

\begin{tabular}{|c|c|c|c|c|c|c|c|c|c|c|c|c|c|}
\hline \multirow[t]{2}{*}{ Species } & \multicolumn{2}{|c|}{$\begin{array}{l}\text { Number of } \\
\text { parameters }\end{array}$} & \multicolumn{2}{|c|}{ ROC } & \multicolumn{3}{|c|}{$\begin{array}{l}\text { Effect of vegetation on } \\
\text { projected range } \\
\text { (percentage change) }\end{array}$} & \multicolumn{2}{|c|}{ Best variable in SDM } & \multicolumn{2}{|c|}{$\begin{array}{l}\text { Range change } \\
\text { NON-VEG }\end{array}$} & \multicolumn{2}{|c|}{$\begin{array}{c}\text { Range change } \\
\text { VEG }\end{array}$} \\
\hline & $\begin{array}{l}\text { NON- } \\
\text { VEG }\end{array}$ & VEG & $\begin{array}{l}\text { NON- } \\
\text { VEG }\end{array}$ & VEG & T2009 & T2039 & T2099 & NON-VEG & VEG & T2039 & T2099 & T2039 & T2099 \\
\hline AREL & 11 & NA & 0.966 & NA & $\mathrm{NA}$ & NA & NA & TMPMAX_10-03 & NA & -5.6 & -3.1 & NA & NA \\
\hline ASFL & 8 & 8 & 0.99 & 0.991 & -9.98 & -12.73 & -12.23 & TMPMIN_11-03 & $\begin{array}{l}\text { Bouteloua } \\
\text { eriopoda }\end{array}$ & -18.5 & -61.4 & -9.5 & -26.8 \\
\hline ASNE & 10 & 12 & 0.99 & 0.987 & -33.65 & -15.89 & -109.85 & SOLAR_MAY & $\begin{array}{l}\text { Bouteloua } \\
\text { eriopoda }\end{array}$ & -4.6 & -47.2 & -17.2 & -16.1 \\
\hline ASTI & 7 & 9 & 0.923 & 0.918 & -4.20 & -3.08 & -4.44 & TMPMIN_10-03 & $\begin{array}{l}\text { TMPMAX_10- } \\
03\end{array}$ & -0.3 & -0.7 & -1.5 & -0.5 \\
\hline ASVE & 4 & 5 & 0.96 & 0.935 & -2.19 & -1.54 & -3.00 & SOLAR_MAY & $\begin{array}{l}\text { Bouteloua } \\
\text { eriopoda }\end{array}$ & -13.8 & -41.6 & -13.2 & -42.1 \\
\hline CRCE & 7 & 8 & 0.98 & 0.98 & -2.20 & -9.09 & -14.76 & TMPMIN_10-04 & $\begin{array}{l}\text { Quercus } \\
\text { gambelii }\end{array}$ & -39.8 & -45.5 & -44.0 & -36.1 \\
\hline CRLE & 9 & NA & 0.98 & NA & NA & NA & NA & SOLAR_MAY & NA & -4.0 & -7.6 & NA & NA \\
\hline DIDO & 6 & 9 & 0.983 & 0.959 & -12.50 & -13.78 & -9.93 & TMPMAX_11-03 & $\begin{array}{l}\text { Larrea } \\
\text { tridentata }\end{array}$ & -9.6 & -5.3 & -11.0 & -2.4 \\
\hline ELKI & 7 & 8 & 0.995 & 0.995 & -1.35 & -1.06 & -3.28 & PPTAVG_07-09 & $\begin{array}{l}\text { PPATAVG_07- } \\
09\end{array}$ & -16.3 & -11.3 & -16.1 & -12.9 \\
\hline GOMO & 3 & 4 & 0.988 & 0.965 & -1.94 & -2.60 & -2.50 & TMPMAX_04-09 & Encelia farinosa & -16.1 & 0.0 & -16.6 & -0.6 \\
\hline HESU & 7 & NA & 0.98 & NA & NA & NA & NA & TMPMIN_11-03 & NA & -20.1 & -4.9 & NA & NA \\
\hline HOMA & 6 & 6 & 0.918 & 0.919 & -1.38 & -6.68 & -6.09 & TMPMAX_11-04 & $\begin{array}{l}\text { Bouteloua } \\
\text { eriopoda }\end{array}$ & -34.3 & -49.1 & -29.0 & -45.3 \\
\hline PHHE & 10 & NA & 0.889 & NA & NA & NA & NA & SOLAR_MAY & NA & $\begin{array}{l}-6.4 \\
\end{array}$ & -24.9 & NA & NA \\
\hline SAAT & 3 & 2 & 0.97 & 0.967 & -0.60 & -14.74 & -11.77 & PPTAVG_07-09 & $\begin{array}{l}\text { Larrea } \\
\text { tridentata }\end{array}$ & -27.7 & -23.0 & -17.5 & -14.4 \\
\hline SCGR & 8 & 9 & 0.887 & 0.869 & -1.49 & -1.81 & -0.31 & PPTAVG_05-09 & $\begin{array}{l}\text { PPTAVG_05- } \\
09\end{array}$ & -7.1 & -41.2 & -7.5 & -39.3 \\
\hline TEOR & 11 & NA & 0.982 & NA & NA & NA & NA & TMPMAX_11-03 & NA & -45.2 & -71.5 & NA & NA \\
\hline
\end{tabular}




\section{Range Expansions and Contractions}

Birds

The plant-based SDMs predicted that the ranges of 13 of 15 bird species will contract between 2009 (contemporary) and 2039, and two will expand (fig. 4). In contrast, the ranges of 4 bird species are predicted to expand between 2009 and 2099, and the ranges of 11 bird species are predicted to contract. In 13 of 15 species, changes in range were larger by 2099 than by 2039 (fig. 5A). In only two cases did bird species whose range contracted by 2039 reverse themselves and show a positive gain by 2099 (black-throated gray warbler and gray vireo [Vireo vicinior]). Sagebrush sparrow (Artemisiospiza nevadensis) and black-throated sparrow (Amphispiza bilineata) are predicted to have the greatest range expansions in 2039 and 2099, respectively, whereas red-naped sapsucker (Sphyrapicus nuchalis) and pygmy nuthatch are predicted to lose the most range in both time periods. Overall range contractions were larger than range expansions, with 92 percent contraction predicted for red-naped sapsucker compared to 58 percent range gain for gray vireo.

Incorporation of plants in SDMs generally reduced projected gains in bird ranges while increasing projected losses (table 3). Incorporating plants into bird SDMs reduced contemporary range an average of 8.5 percent (2009), 18.5 percent in 2039, and 25.8 percent in 2099 (table 3). Four species (flammulated owl [Otus flammeolus], pygmy nuthatch, red-naped sapsucker, and Williamson's sapsucker) associated with Ponderosa Pine are predicted to lose between about 37-85 percent of their range by 2099. Of four species associated with big sagebrush, three (Brewer's sparrow [Spizella breweri], gray flycatcher, sage thrasher [Oreoscoptes montanus]) are predicted to lose about 34-80 percent of their range, whereas sage sparrow is predicted to gain about 18 percent of its range. Of the two species associated with creosote brush, black-throated sparrow showed a range gain by 2099 (34.38 percent), whereas Le Conte's thrasher showed a range loss (-37.37 percent). Of the two species associated with juniper, gray vireo showed a large range gain (58.17 percent) by 2099 , whereas juniper titmouse showed a modest range loss (-10.26 percent). Of the two remaining bird species, blackthroated gray warbler, which was not associated with a plant, showed a modest range gain by 2099 (10.56 percent), whereas Virginia's warbler (Oreothlypis virginiae), associated with Gambel's oak (Quercus gambelii), showed a modest range loss (-6.84 percent).

\section{Reptiles}

Species distribution models for reptiles that did not include the effects of plant species predicted that, assuming no dispersal, the ranges of all reptile species will contract to some degree between 2009 and 2039. The ranges of 13 of 16 reptile species are projected to contract significantly (5.6-45.2 percent) between 2009 and 2039, whereas 3 species are predicted to have reductions of less than 5 percent (New Mexico whiptail, tiger whiptail [Aspidoscelis tigris], and rock rattlesnake). For 10 of 16 species, range contractions were larger in 2099 (0.7-71.5 percent) than in 2039 (fig. 5B). Conversely, for six species, range contractions by 2099 were smaller than those occurring by 2039. Three species (Arizona black rattlesnake [Crotalus cerberus], common lesser earless lizard [Holbrookia maculata], and ornate box turtle) showed range decreases of more than 30 percent by 2039, whereas Gila spotted whiptail (Aspidoscelis flagellicauda), New Mexico whiptail, common lesser earless lizard, and ornate box turtle showed range decreases of more than 45 percent by 2099. No species had ranges that were predicted to remain static (persist) during any time period (fig. 6). However, Morafka's desert tortoise had a range that contracted in 2039, and then apparently showed a slight reversal, to end with a prediction of effectively no change in range ( 0 percent) by 2099. 


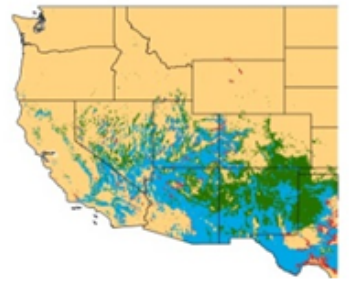

Gray Vireo

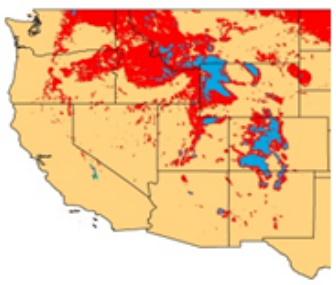

Red-naped

Sapsucker

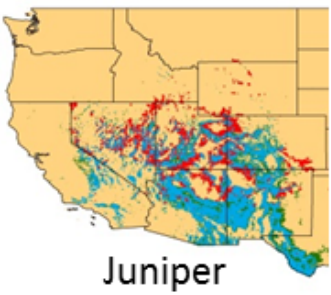

Titmouse

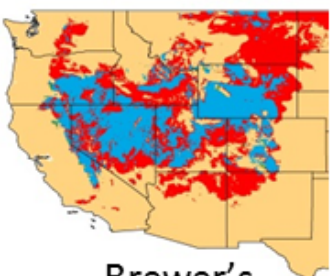

Brewer's

Sparrow

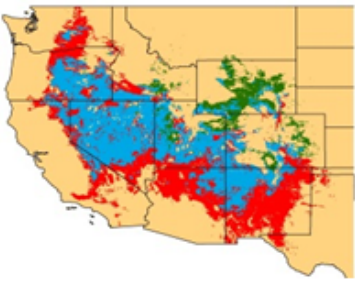

Gray Flycatcher

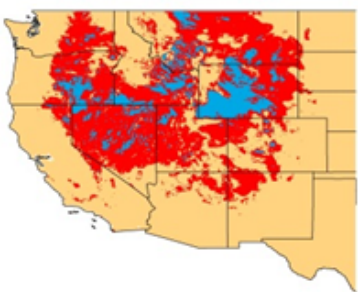

Sage Thrasher

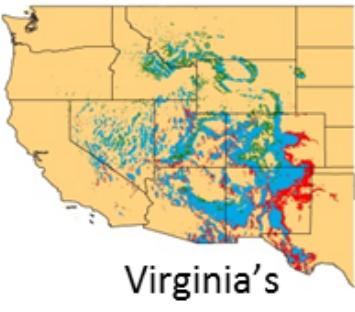

Warbler

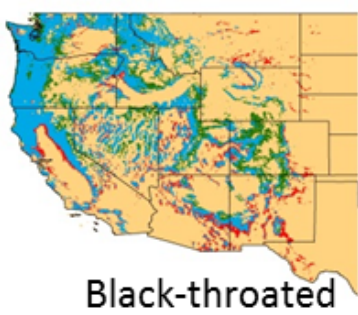

Gray Warbler

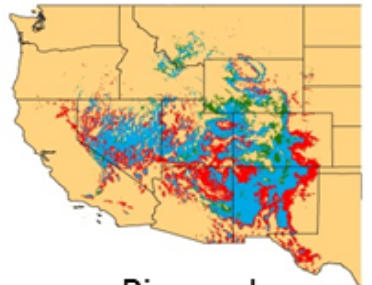

Pinyon Jay

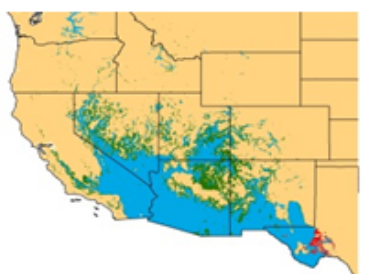

Black-throated

Sparrow

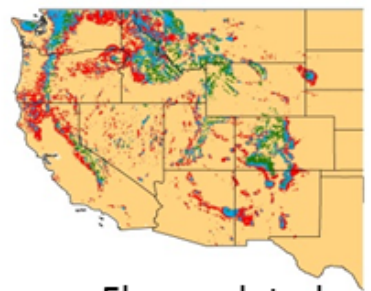

Flammulated

Owl

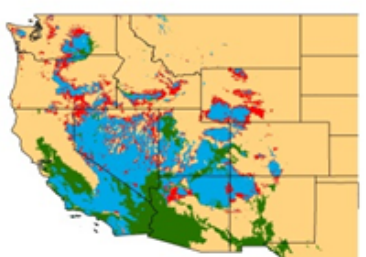

Sage Sparrow

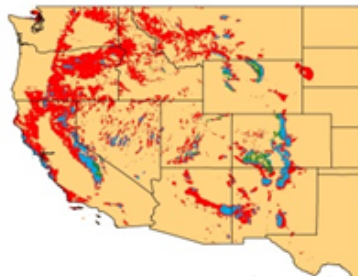

Pygmy Nuthatch

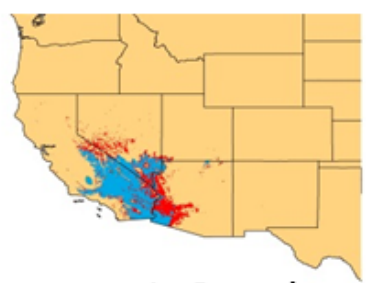

LeConte's

Thrasher

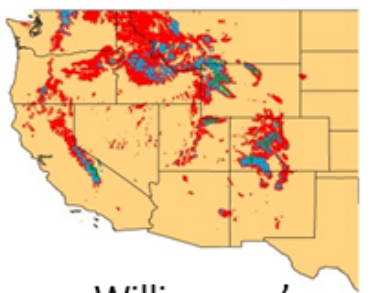

Williamson's

Sapsucker

\section{Changes in Range}

\begin{tabular}{|l}
\hline Expansion \\
Contraction \\
Refuge \\
\hline$\quad$ Non-suitable area \\
\hline
\end{tabular}

Figure 4. Projected changes in range for 15 bird species between 2009 (contemporary time) and 2099. Red areas indicate range contraction, green areas represent range expansion, blue areas identify areas where range persisted (refuge), while tan areas indicate non-suitable areas in both time periods. 

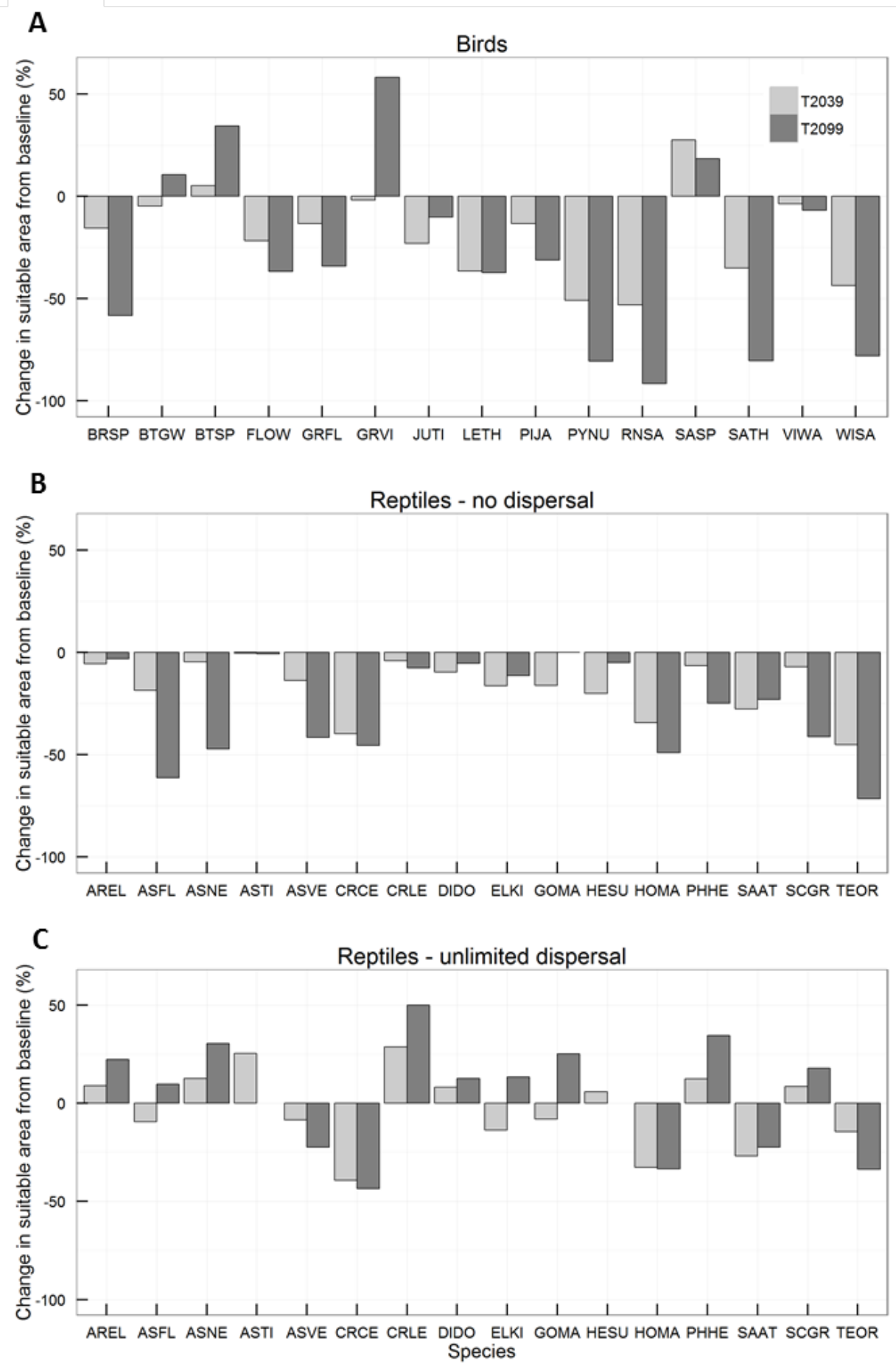

Figure 5. Graphs showing projected changes in range for 15 bird species (A) and 16 reptile species (B,C, differentiated by dispersal assumptions) between contemporary time (2009) and 2039 (T2039; light gray boxes), and between contemporary time and 2099 (T2099; dark gray boxes). Abbreviations for bird and reptile species are explained in table 1. Results for birds and reptiles are based on models that include vegetation if plants were identified in variable selection (see section, "Materials and Methods"). 


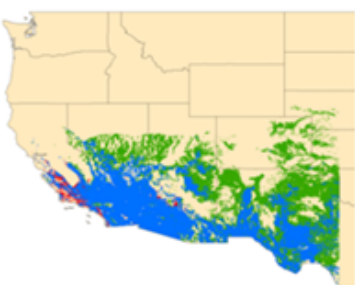

Glossy Snake

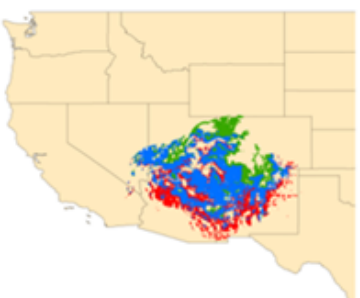

Plateau Striped Whiptail

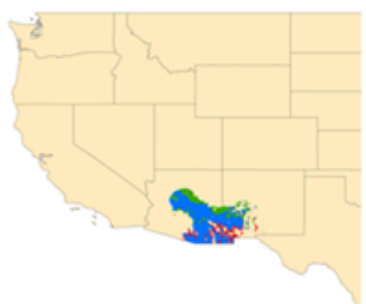

Madrean Alligator Lizard

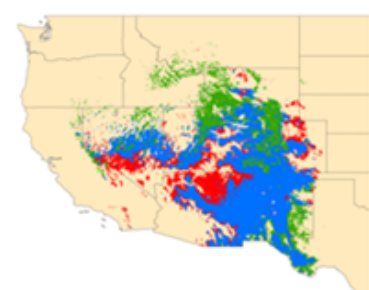

Greater Short-horned Lizard

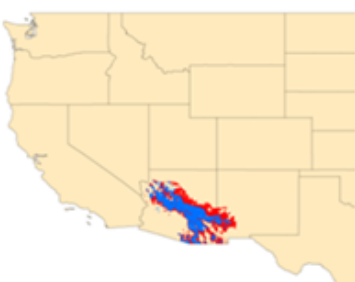

Gila Spotted Whiptail

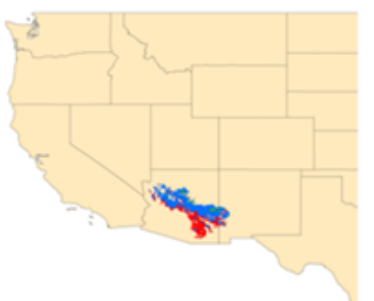

Arizona Black Rattlesnake

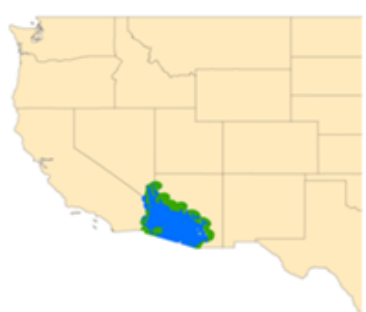

Desert Tortoise

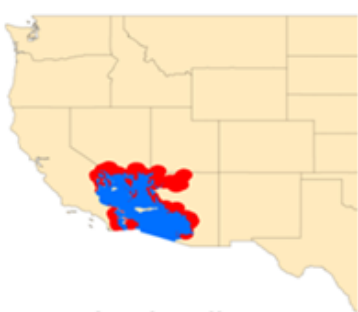

Chuckwalla

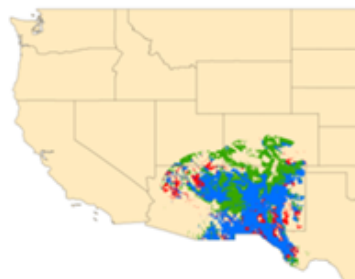

New Mexico Whiptail

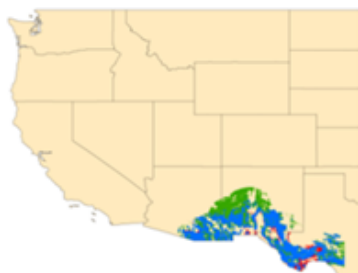

Rock Rattlesnake

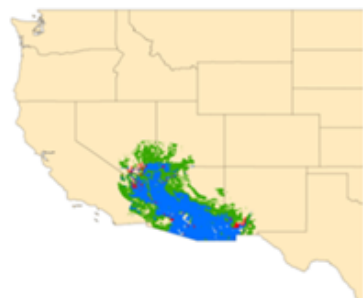

Gila Monster

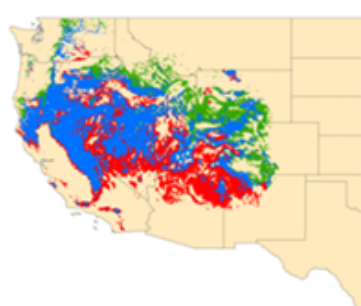

Sagebrush Lizard

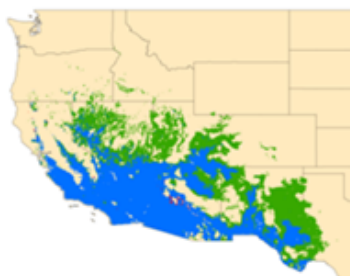

Tiger Whiptail

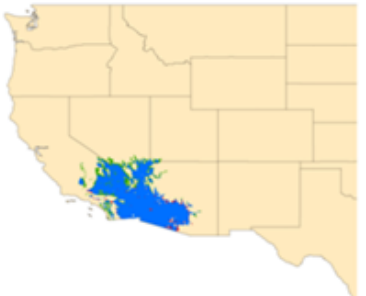

Desert Iguana

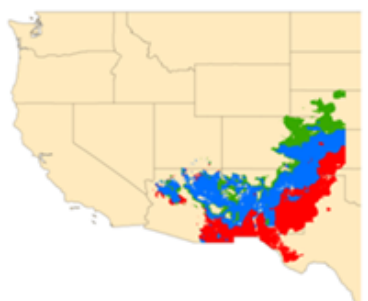

Common Earless LIzard

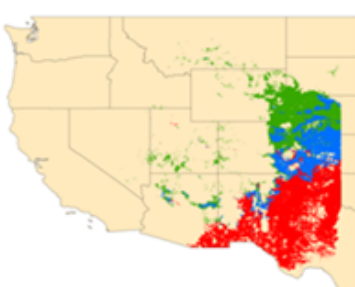

Ornate Box Turtle

\section{Changes in Range}

Expansion
Contraction
Refuge
$\square$ Non-suitable area

Figure 6. Projected changes in range for 16 reptile species between 2009 (contemporary time) and 2099. Red areas indicate range contraction, green areas represent range expansion, blue areas identify areas where range persisted (refuge), while tan areas indicate non-suitable areas in both time periods. 
Including plants in the models resulted in greater range contraction over time, with an average of 7.5 percent by 2039 and 16.2 percent by 2099. For reptile species associated with plant species, predictions over time based on SDMs including plants follow the same pattern as predictions based on SDMs without plants, except for two species; New Mexico whiptail is predicted to lose 5-45 percent of its range and Arizona black rattlesnake is expected to lose 36-46 percent of its range. Although for five species, the decrease in predicted habitat is greater in the long term, the predicted loss in range often is less than 5 percent between time periods. For example, common chuckwalla is predicted to lose 27.7 percent by 2039 and 23.0 percent by 2099 (table 4). On the other hand, for some species, predictions become more extreme towards the end of the century, regardless of the differences between short and long time scales; reductions of as much as 72 percent of the range are predicted for Gila spotted whiptail, New Mexico whiptail, common lesser earless lizard, ornate box turtle, and Arizona black rattlesnake.

Although our analyses did not focus on the assumption of unlimited dispersal, calculations that assume unlimited dispersal and compare different time periods indicate that for those reptile species for which ranges are likely to increase, the increase is relatively moderate (as much as 15 percent by 2039 and 35 percent by 2099; fig 5C). It is more noteworthy that for some species, such as the Arizona lack rattlesnake, the assumption of unlimited dispersal has very little effect on the amount of predicted range loss (43 percent loss by 2099 assuming unlimited dispersal compared to 46 percent loss with no dispersal).

\section{Group Meta-Analysis}

\section{Birds}

When we examined the explanatory power of each class of variables across all bird SDMs (that is, the roles, if any, of trans-specific drivers related to projected future ranges), temperature and precipitation variables were the most influential in SDMs that did not contain plant species, followed by landscape variables (fig. 3). In these non-plant SDMs, the range of variability (as expressed by the 25th and 75th percentiles) in explanatory power was similar among variable classes. Inclusion of plant species across bird SDMs indicated that precipitation had the largest variability in explanatory power, whereas landscape and temperature classes were similar (fig. 3). In plant-based SDMs, plants were the least influential variable class; however, the range of variability of plants was the narrowest, demonstrating that it was the most stable variable class, followed by landscape, temperature, and precipitation.

There were 17 significant correlations $(P \leq 0.1)$ between projected range changes (by 2039 or by 2099) and any predictor variable (calculated for contemporary times) that relates to biological attributes, habitat fragmentation, landscape, or climate (fig. $7 \mathrm{~A}$ ), with the strength of most correlations increasing by 2099. Three correlations involved fragmentation metrics (coefficient of variation of patch area, that is, patch size, AREA_CV; mean Euclidean nearest neighbor, ENN_MN; and patch-shape complexity SHAPE_AM), 13 involved PRISM climatic variables (12 temperature and one precipitation variable), and1 involved a biological attribute (clutch size, CLUTCHSIZE). When we considered only the 11 migratory species (short-, medium-, and long-distance migrants), excluding permanent residents (species that stay within their breeding range year-round), number of months on the breeding ground (NMBG) also was significantly correlated with projected range change in both time periods. Projected range change also differed between cavity and cup nesting species; the ranges of cavity nesters declined more by $2039(P \leq 0.01)$ and by $2099(P \leq 0.05)$ than cup nesting species. The strongest correlation with range changes in the 2039 time period involved ENN_MN (rho $=-0.69)$, whereas maximum winter 
temperature (TMPMAX_W) had the strongest correlation with range changes by 2099 (rho $=0.75)$. The sign of the coefficient for ENN_MN was negative, indicating that species with the largest patch isolation under contemporary conditions had the largest range contractions by 2039 and 2099. The other two significant fragmentation metrics characterized variability in patch configurations, and both had positive coefficients - the AREA_CV (rho =0.66), and SHAPE_AM (rho =0.60). Of the 13 significant PRISM climate variables, only 1 precipitation variable (average spring precipitation, PPTAVG_P) was significant (rho $=-0.52$ ), and it was the only climate variable with a negative coefficient. The other 12 significant climate variables characterized temperature in each season (summer, fall, winter, spring), and all had positive coefficients.

Fragmentation metrics. - Created from contemporary (2009) range maps - and linear regression explained 43 percent of the variability in future range changes (appendix 6). The mean distance to nearest neighbor (ENN_MN) explained 30-34 percent of variability (expansion or contraction) in future range (figs. 6.1 and 6.2 ), with negative coefficients for both time periods, indicating that increased patch isolation is implicated in increased breeding range contraction in the future. In contrast, the variability in patch area (AREA_CV) explained 29-47 percent of future range variability, with positive coefficients (figs. 6.3 and 6.4), indicating that species with the largest patchsize heterogeneity in contemporary breeding range likely will have the largest range expansions. Finally, the area-adjusted patch-shape (SHAPE_AM), for example, complexity, explained 25-46 percent of the variability in range with a quadratic equation (figs. 6.5 and 6.6), indicating that some degree of patch-shape complexity will result in range expansions, but too much complexity can negatively affect range. Lastly, the largest patch index (LPI), which equals the percent of the landscape that the largest patch comprises, explained between 22-28 percent of future range variability with quadratic equations (figs. 6.7 and 6.8), suggesting that larger patches will result in range expansions, but too large a contiguous patch will negatively affect range.

Biological attributes and linear regression explained 38 percent of the variability in future range changes (appendix 6). Number of months on the breeding ground (NMBG) explained 30-32 percent of variability in range change with a quadratic relation (figs. 6.9 and 6.10). The four species classified as permanent residents (that is, non-migratory residents - pinyon jay, juniper titmouse, Le Conte's thrasher, pygmy nuthatch), typically within their breeding range year-round, are projected to have range contractions from -13 to -51 percent by 2039 , and from -10 to 81 percent by 2099 . When only the 11 migratory species were considered (short-, medium-, and long-distance migrants), NMBG explained 27-31 percent of variability in range expansion or contraction, and had positive (linear) coefficients for both time periods, indicating that the more time a species spent on the breeding grounds, the smaller the projected range contraction. Lastly, clutch size (number of eggs) explained between 27 and 38 percent of future range variability with linear and quadratic equations (figs. 6.11 and 6.12), suggesting that species with larger brood sizes (e.g., pygmy nuthatch and juniper titmouse) will experience greater range contraction than species with smaller brood sizes. 


\section{A}

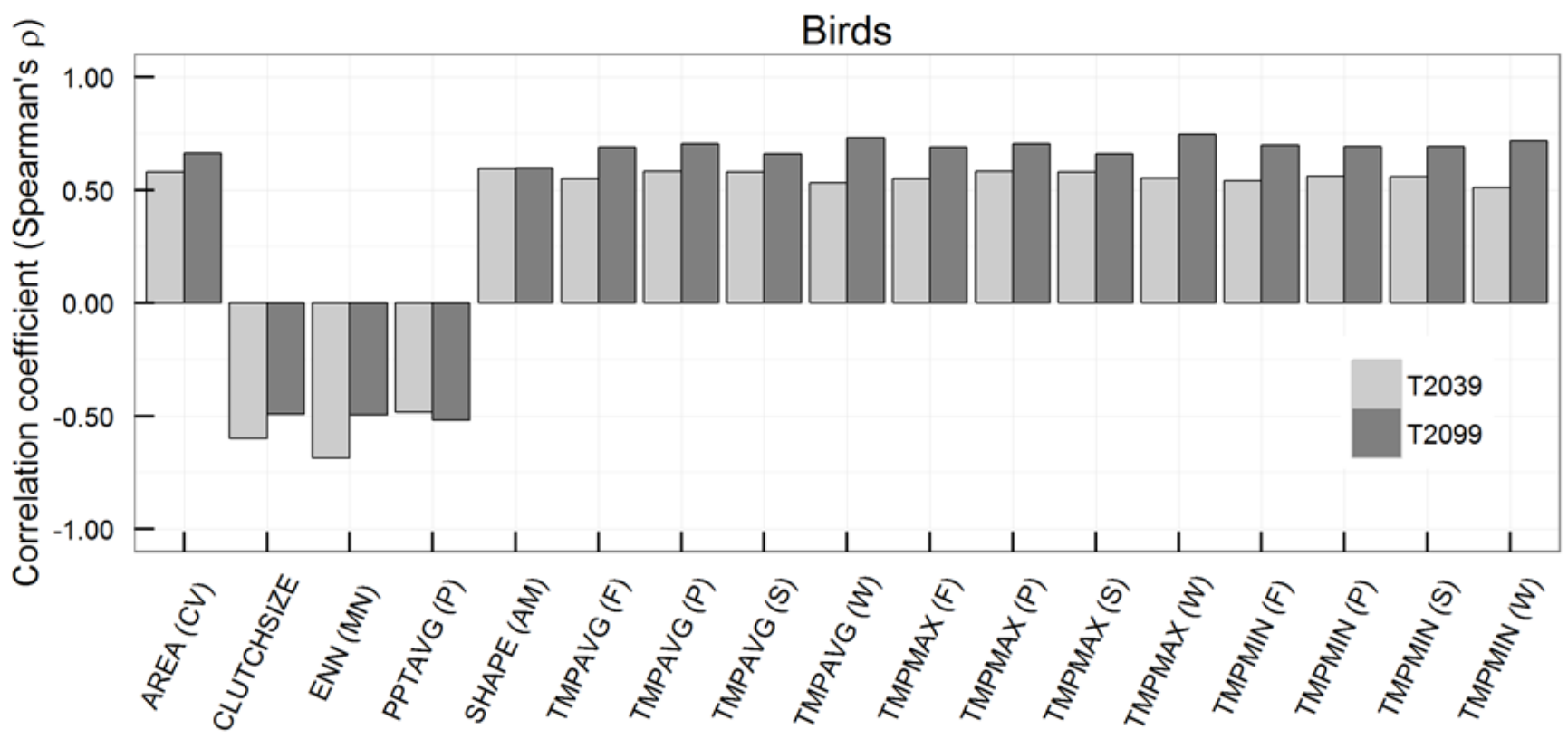

\section{B}

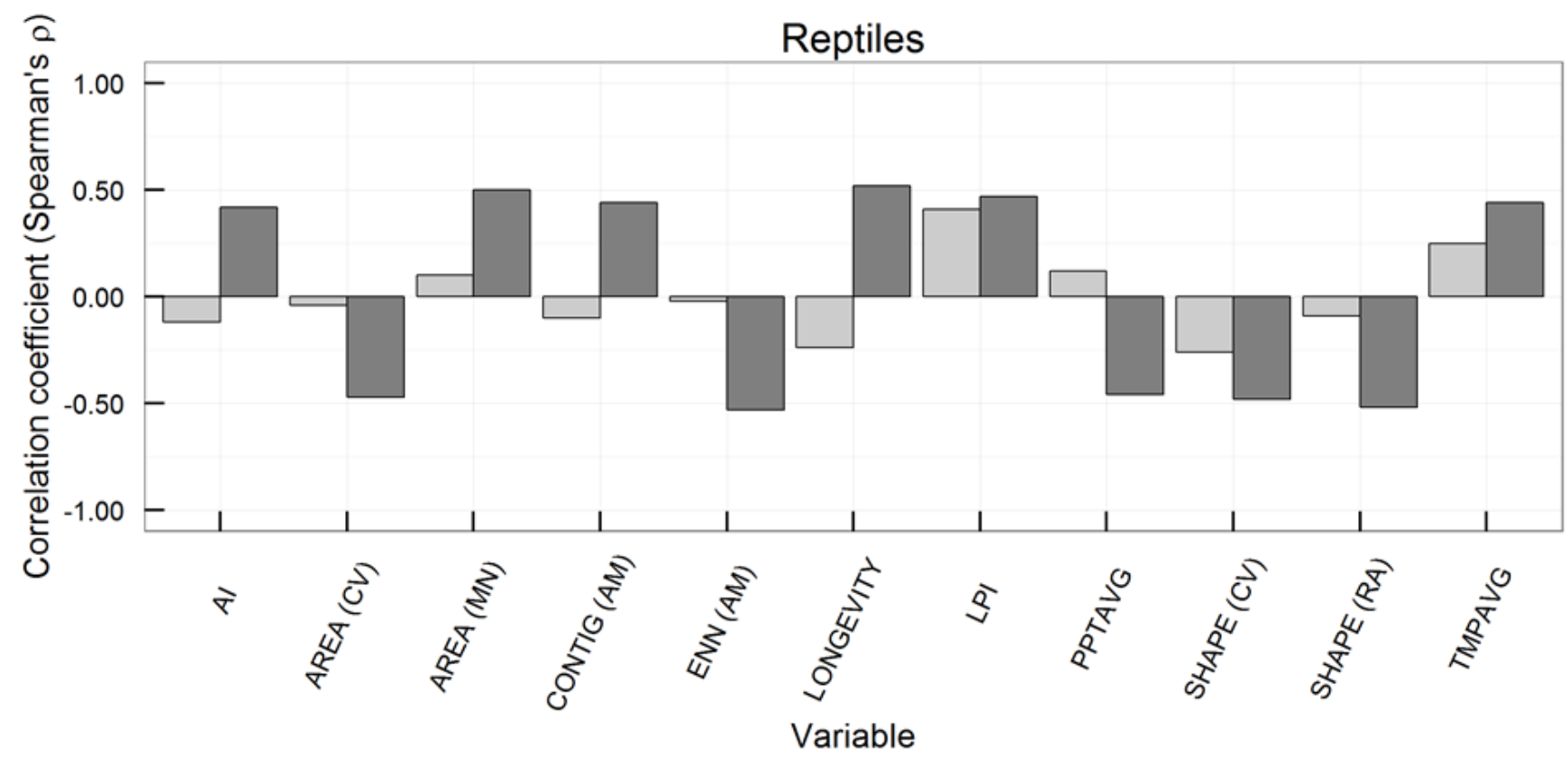

Figure 7. Graphs showing select correlations $(P<0.1)$ between environmental variables and magnitude of range expansions or contraction for birds (A) and reptiles (B), calculated for 2039 (light gray boxes) and 2099 (dark gray boxes). For this analysis, biological attribute, habitat fragmentation, landscape, and climatic variables all describe contemporary (2009) features or conditions. Precipitation and temperature variables represent seasons that are species-specific for reptiles. Abbreviations for variables are described in table 2. 
Climatic variables. - Created from contemporary (2009) range maps - and linear regression explained 64 percent of the variability in future range changes (appendix 6). The average maximum winter temperature (TMPMAX_W) explained 47-64 percent of variability in range change, with a positive quadratic (figs. 6.13 and 6.14), whereas average spring precipitation (PPTAVG_P) explained 23-33 percent (figs. 6.15 and 6.16), with a negative quadratic. While contemporary climatic variables had the strongest correlations with projected range changes (magnitude and direction) for 15 bird species, they were insignificant predictors in multivariate linear regressions whenever certain pairs of fragmentation and life-history metrics were introduced (table 5, equations 1-4). Strong fragmentation covariates included aggregation index (AI), area-adjusted Euclidean nearest neighbor (ENN_AM), largest patch index (LPI), edge density (ED), or variation in mean patch size (AREA_CV). Three variables representing biological attributes also were significant predictors in our best models: (1) number of months on the breeding grounds (NMBG), (2) clutch size (CLUTCHSIZE), and (3) body mass (BODYMASS). Collectively, these bird equations explained 55-70 percent of variability in future range changes in 2039, and 59-70 percent in 2099.

Table 5. Multiple regression equations for birds that predict changes in species' ranges (2039 or 2099) using biological attributes and habitat-fragmentation metrics created from contemporary range maps (2009).

$\left[\mathrm{R}^{2}\right.$, coefficient of determination]

\begin{tabular}{lcc}
\hline Linear regression & Equation & Adjusted R \\
\hline T2039 $=853.544-(2.661 *$ AI $)-(0.076 *$ ENN_AM $)$ & $1 \mathrm{a}$ & 0.56 \\
T2099 $=1824.31-(7.106 *$ AI $)-(0.147 *$ ENN_AM $)$ & $1 \mathrm{~b}$ & 0.59 \\
T2039 $=679.237-(2.005 *$ LPI $)+(0.185 *$ ED $)-(0.085 *$ ENN_AM $)$ & $2 \mathrm{a}$ & 0.56 \\
T2099 $=1545.953-(7.027 *$ LPI $)+(0.339 * \mathrm{ED})-(0.187 *$ ENN_AM $)$ & $2 \mathrm{~b}$ & 0.67 \\
$\begin{array}{l}\text { T2039 }=-3.159+(0.021 * \text { AREA_CV })-(10.196 * \text { CLUTCHSIZE })- \\
(0.272 * \text { BODYMASS })\end{array}$ & $3 \mathrm{a}$ & 0.56 \\
$\begin{array}{l}\text { T2099 }=-56.271+(0.065 * \text { AREA_CV })-(14.686 * \text { CLUTCHSIZE })- \\
(0.555 * \text { BODYMASS })\end{array}$ & $3 \mathrm{~b}$ & 0.63 \\
T2039 $=779.529+(13.361 *$ NMBG $)-(1.003 *$ NMBG_2 $)-(2.746 *$ AI & $4 \mathrm{a}$ & 0.70 \\
$-(0.07 *$ EEN_AM $)$ & & \\
T2099 $=1486.317+(43.699 *$ NMBG $)-(2.992 *$ NMBG_2 $)-(6.927 *$ & $4 \mathrm{~b}$ & 0.70 \\
AI $)-(0.12 *$ EEN_AM $)$ & & \\
\hline
\end{tabular}




\section{Reptiles}

When we examined the explanatory power of each class of variables across all reptile SDMs, temperature variables had the largest explanatory power in reptile SDMs that did not contain plant species, followed by precipitation and landscape variables, respectively (fig. 3A). In non-plant SDMs, temperature had the largest variability in explanatory power (as expressed by the 25th and 75th percentiles), followed closely by precipitation, and last by landscape. When plants were included in reptile SDMs, they were the most influential variable class, followed by precipitation, temperature, and landscape (fig. 3B). However, the range of variability in the explanatory power of plants was the largest (for example, they were the least consistent variable class), followed by precipitation, temperature, and landscape.

There were 11 moderately significant correlations $(P \leq 0.10)$ between reptile predictor variables (biological attribute, habitat fragmentation, landscape, and climatic variables) and predicted changes in range (fig. 7B). Only 2 out of 11 correlations involved climate, at the longer time scale (2009-2099), summer precipitation (PPTAVG_07-09) and temperature (TMPAVG_07-09). The sign of the coefficient for summer precipitation was negative, indicating that species whose contemporary ranges have relatively higher summer precipitation are likely to have the greatest contraction in their future range. Additionally, only one significant correlation was noted between a biological attribute (longevity) and increase or decrease in predicted range at T2099. The strongest correlations at a shorter time scale (T2039) related to the largest patch index (LPI), whereas at T2099, the strongest correlation was with a metric representing area-weighted mean Euclidian distances to nearest neighbors (ENN_AM). Other fragmentation metrics that were significant included area-weighted mean patch size and its coefficient of variation (AREA_MN, AREA_CV), variability in the patch shape index (SHAPE_RA), and to a lesser degree the aggregation index (AI, a measure of how compactly patches are aggregated) and areaweighted mean contiguity index (CONTIG_AM, a measure of contiguity of patches; for example, large contiguous patches result in large index values).

Linear regression and fragmentation metrics developed from contemporary range maps explained 47 percent of the variability in future reptile range changes. Analyses of individual variables at longer time scales (2009-2099) indicated 11 significant $(P \leq 0.10)$ univariate regressions (either linear or quadratic) that describe trends similar to those observed in birds (fig. $7 B$ ). For example, relatively large variability in range contraction was explained by the mean area of patches ( $\sim 47$ percent), suggesting that larger patches correlate with less range contraction in the future (fig. 6.17). Likewise, the coefficient of variation in the patch area was negative and explained 44 percent of the variability in range changes, suggesting that larger variation in patches is related to greater range loss in the future (fig. 6.18). Similarly, area-adjusted mean Euclidean distance to nearest neighbor explained 27 percent of the variability in range changes and had a negative coefficient, indicating that increased patch isolation is implicated in increased range contraction by 2099 (fig. 6.19). Two indices related to patch configuration, the aggregation index (fig. 6.20) and the largest patch index (fig. 6.21), explained 25 percent and 21 percent of variability in range decline by 2099, respectively. Species whose ranges are composed of patches that are large with less edge are projected to have smaller decreases in range compared with species associated with small patches and lots of edge. A measure of shape (fig. 6.22), complexity of patch shape compared to a square, and its coefficient of variation (SHAPE_CV [fig. 6.23]) explained 31 and 20 percent, respectively, of variation in range contraction by end of century. 
The coefficients of both of these regressions are negative, indicating that species whose ranges are composed of patches with more complex shapes and whose ranges have greater variation will have the most range contraction by 2099. Finally, area-weighted mean contiguity index (CONTIG_AM) explained 25 percent of variation in range decline in reptiles with a positive coefficient (fig. 6.24), indicating that species ranges that are currently more contiguous are projected to have more of their habitat persist into the future. In contrast to the bird meta-analysis, we did not find statistically significant multivariate relations between predicted reptile range contractions and variable classes.

\section{Discussion}

\section{Species Distribution Models}

Incorporating plant distribution data in SDMs generally increased projected range contractions for birds and reptiles, while decreasing projected range expansions, because plant migration rates did not keep pace with a shifting climate envelope (Cole and others, 2011). This lag effect resulted in magnified range losses for bird and reptile species that relied closely on specific plants for some aspect of their life or natural histories (for example, food, hunting, and breeding). Thus, SDMs that did not incorporate individual plant species vital to the survival of bird and reptile species seem less specific or useful, highlighting the importance of plants in conservation planning. These findings are partially supported by Sohl (2014), who assessed the effects of broad land-cover types (for example, forest, grass, and shrub) on projected bird ranges. Two bird species that we modeled (gray vireo and pygmy nuthatch) also were modeled by Sohl, allowing us to compare results. Both studies predict that gray vireo will have large gains in range, but there was a large divergence in predicted range for pygmy nuthatch-Sohl projected an approximate 5 percent gain by 2075, whereas we projected an 81 percent loss by 2099. Although there were differences in methodologies, the discrepancy in projected range seems related to a "forest class" variable Sohl created, grouping together multiple tree species when building and testing SDMs. Paleoecological studies of past climate shifts have shown that plant assemblages change over time (Davis, 1981; Cole 1985) because of the successional status, dispersal ability, and climatic tolerances of each species (Cole, 2010). Therefore, we focused on specific species of long-needled pines (ponderosa pine, Jeffrey pine [Pinus jeffreyi]) known to be important to foraging and nesting pygmy nuthatch (Kingery and Ghalambor, 2001). This large discrepancy in projected range indicates the importance of conceptual diagrams that guide the development of SDMs that link focal animal reliance on certain plant species during specific life stages, compared to generic vegetative structure or functional classes.

The SDMs predict large range contractions for most bird species we modeled, including species that are currently common, with the severity of contractions generally increasing with time. Four bird species are predicted to lose 78-92 percent of breeding range compared to contemporary range maps. Three species (pygmy nuthatch, red-naped sapsucker, Williamson's sapsucker) are strongly associated with coniferous forests (for example, ponderosa pine, Jeffrey pine, and Douglas-fir), and sage thrasher is associated with big sagebrush. The coniferous forest species are projected to lose considerable amounts of the northern part of their ranges and also to contract along their edges. Supporting these findings, additional researchers have predicted sharp contractions in ponderosa pine, Douglas-fir, and sagebrush ecosystems in the next century because of climate change, fire, drought, and insect infestations (Notaro 
and others, 2012; Williams and others, 2012). Furthermore, an independent study that examined potential bird ranges throughout North America, but without inclusion of plant distribution data or landscape variables, predicted that the same four species we modeled (pygmy nuthatch, red-naped sapsucker, Williamson's sapsucker, sage thrasher) will have range losses of 69-97 percent (National Audubon Society, 2013).

Four bird species that we modeled are projected to have an increase in suitable range (11-58 percent) by 2099 - Black-throated gray warbler, gray vireo, black-throated sparrow, and sagebrush sparrow. Only two of these species (black-throated sparrow and sagebrush sparrow) are projected to have an increase in suitable range by 2039 (47 and 68 percent, respectively). These species, and gray vireo, are associated with shrubby habitats and have the most southerly distributions, and their ranges are predicted to persist or increase in the southern part of their ranges. Black-throated gray warbler, the fourth species whose range was predicted to increase by 2099 (by 11 percent), breeds primarily in forests of pinyon-juniper, pine, and mixed oak-pine, but also is present in open coniferous and mixed coniferous-deciduous woodland with a brushy understory (Guzy and Lowther, 2012). We predict that its contemporary range will persist primarily in the western, non-pinyon-juniper parts of its range by 2099.

Assuming no dispersal, we predict severe contractions (by as much as 72 percent) in ranges of several reptile species, including locally common western United States reptiles over the coming century. These projections for loss of habitat in reptiles are similar to those of other modeling studies (for example, western rattlesnakes, not specifically including the species we modeled, Lawing and Polly, 2011; lizards, Sinervo and others, 2010). Sinervo and others (2010) documented recent losses in the ranges of some lizard species and localized extinctions in the Southwest because of climate change, and predicted a 20-percent global extinction across 34 lizard families by 2080. This includes a 54percent local extinction for all North American Sceloporus species (Sinervo and others, 2010), including sagebrush lizard, for which we predict a 39-41 percent contraction in range by 2099.

Previous studies predicting effects of climate change on ectotherms have noted that temperature and precipitation changes may combine to negatively affect ecophysiological envelopes, resulting in reduced availability of suitable thermal-climate-space for reproduction, foraging, and digestion (Sinervo and others, 2010; Clusella-Trullas and others, 2011; Buckley and others, 2012). Our results implicated winter temperatures as being particularly influential explanatory variables in predicting extent of contemporary ranges for one-half of focal reptile species, with summer precipitation noted for an additional three species. In particular, minimum winter temperatures were the most important variable driving the distribution of Arizona black rattlesnake, a species that is currently common, but for which there is substantial conservation concern because of its limited range and use of forested or mesic 
habitats (Nowak and others, 2016). The effects of warmer winter temperatures on the life history of this species are already documented; this species uses cooler hibernation locations than those of congeners at some low-altitude locations in Arizona (Nowak and others, 2016). Conversely, an increase in winter temperatures between 1987 and 2010 was implicated in changes in phenology (delayed onset of active, foraging, and hibernation seasons) that may benefit asp vipers (Vipera aspis; Rugerio and others, 2013).

Our results for Morafka's Desert Tortoise (an initial range contraction of as much as 20 percent by 2039 , followed by a reversal in rate of decline to near net-zero loss by 2099) seems to be different from other models predicting substantial loss of range for all species of Southwestern desert tortoises (Barrows, 2011; B. Sinervo, J. Lovich, and others, USGS, unpub. data, 2016). This apparent incongruity likely stems from different modeling approaches and assumptions, as well as different scales of modeling (for example, our scale of inference is across the American West, and results are calculated on a coarse scale of $4 \mathrm{~km}$ from a limited set of climatic and abiotic variables). With results similar to ours, Barrows (2011) determined that summer maximum temperatures and terrain ruggedness were the most influential variables in a niche model developed for desert tortoises in the Sonoran Desert part of Joshua Tree National Park. Winter precipitation also was critically important in predicting survival and demography of populations in this same area (Lovich and others, 2014).

\section{Group Meta-Analysis}

The first objective of this meta-analysis was to identify the collective contributions of environmental variables (landscape, climatic, vegetation) in each group (birds or reptiles), and the second objective was to identify trans-specific drivers associated with the changing ranges of each group in 2039 and 2099. For the first objective, climate was the most influential variable class for birds, followed by landscape and plant classes, respectively. In contrast, plants were the most influential variable class for reptiles (only models that included plants were counted), followed by climate and landscape, respectively. Specifically, our results suggest that bird or reptile species that currently (i.e., 2016) occupy warmer locations in any season will have range gains, whereas species that currently occupy wetter spring or summer locations will have range contractions.

For the second objective, contemporary habitat-fragmentation and biological attributes were significantly correlated with future changes in bird ranges, whereas this was less so (but still significant) for reptiles. Differences in the strength of correlations between contemporary habitat-fragmentation variables and the projected range changes of each group may be owing to differences in the scale of patterns and processes for the two groups. Reptiles have smaller distributional ranges compared to birds, smaller home ranges, greater dependence on the availability of specific habitat requirements, and lower dispersal abilities. These biological attributes make reptiles more likely to be affected by factors at a finer scale than the broader landscape scale at which we measured contemporary habitat fragmentation. It also is possible that our meta-analysis results for reptile range fragmentation were not stronger because of interspecific variation in edge use among our focal species, or because of the types of habitats they use. With the exception of Arizona black rattlesnake, none of the reptile species we examined are largely restricted to woodland habitats, whereas most bird focal species are associated with forests or woodlands, and the rest with shrubby habitats. For our focal reptiles, edge effects may be less relevant than for those reptiles that rely on edges in forested patches for foraging and (or) thermoregulation (Carfango and Weatherhead, 2006). 
Several contemporary range-fragmentation variables (Euclidean distance to nearest neighbor, aggregation index, largest patch index, edge density, and variation in patch size) were significant predictors of future range changes for focal bird species, and to a lesser degree for reptiles. For both taxa, the coefficients indicated that species with more fragmented contemporary ranges will have greater range contractions in the future. For example, Euclidean nearest neighbor, conceived from island biogeography, is a patch-isolation metric that is computed as the shortest straight-line distance between patches (McGarigal and others, 2002); thus, its negative coefficient indicates that patch isolation contributed significantly to the vulnerability to range contractions for birds and reptiles. Although effects of range fragmentation could be mitigated in the short term through dispersal (for birds), these effects will be particularly pronounced for non-volant small-bodied reptiles (Araújo and others, 2006), including many of the species we examined. However, our assumptions of limited dispersal abilities may be an oversimplification in the case of large-bodied reptiles - individual Gila monsters (Heloderma suspectum) and Arizona black rattlesnakes are capable of moving several kilometers during favorable (for example, warm and (or) humid) conditions (Nowak, 2009; Nowak and others, 2016); over generations, this could result in substantial changes in occupied range. Morafka's desert tortoises have been documented to move as far as $32 \mathrm{~km}$ (Edwards and others, 2004; but note involvement of humanfacilitated movement); thus, they are potentially are able to disperse even farther than snakes or lizards. However, as noted before, even when range change is calculated based on an assumption of unlimited dispersal, predicted ranges for some species still are likely to contract.

Biological attributes that are correlated with the vulnerability of species were identified, as measured by the degree of range contraction or expansion. For birds, clutch size and nest type (cup or cavity) were correlated with range change. Predicted range contractions were larger for species with large clutch sizes and for cavity nesters. These biological attributes are related, as cavity nesters generally have fewer broods and larger clutch sizes than cup nesters. We also determined that the propensity of a species to migrate, measured as the number of months on the breeding ground, is an indicator of vulnerability to climate change. The four species classified as permanent residents (that is, non-migratory; pinyon jay, juniper titmouse, Le Conte's thrasher, and pygmy nuthatch) that stay within their breeding range year-round are projected to have range contractions from -13 to -51 percent by 2039 , and from -10 to -81 percent by 2099 . When only the 11 migratory species (short-, medium-, and long-distance migrants) were considered, the more time a species spent on the breeding grounds, the smaller its projected range contraction or the larger its projected range expansion. For reptiles, only longevity was correlated with predicted range by 2099 , and the relation was positive; that is, the longer the generation time, the less the range contraction. This relation, however, is mostly driven by several species for which ranges are predicted to contract severely and that have very short life spans. We were unable to assess the effects of longevity for birds, as we lacked comparable data.

Our collective results that synthesized climatic, fragmentation, and biological attributes indicate that bird species whose contemporary breeding ranges are highly fragmented and relatively cool, and that are cavity nesters, are more vulnerable to climate change than bird species with less fragmented and warmer breeding ranges, and that are cup nesters. These results indicate that the most vulnerable bird species are forest and woodland birds, followed by most sagebrush associates. Our results for birds are contrary to those of an independent study in England that reported that habitat fragmentation (that is, patch clumpiness) was positively correlated with range expansions, not contractions, and that climate was the most influential explanatory variable (Bradshaw and others, 2014). However, unlike birds of the 
American West, the English bird community is comprised of species that have persisted through millennia of environmental change and habitat fragmentation and that thus are likely to differ in their responses to fragmentation. Moreover, a more recent and comprehensive synthesis of fragmentation experiments that spanned 35 years, five continents, and multiple biomes and scales, noted that habitat fragmentation (that is, distance to forest edge and patch isolation) reduced biodiversity by 13-75 percent, with negative effects of fragmentation magnified through time (Haddad and others, 2015).

\section{Actionable Science and Management}

The results of this meta-analysis indicate that the effects of climate change on the ranges of species may be minimized through the modification of existing habitats. Namely, managers can increase patch size and size heterogeneity, and reduce patch isolation, through forest and range activities, such as managing for connectivity through habitat conservation and restoration. In an independent but related study, research was conducted in Mexico in anticipation of warmer and drier conditions, to determine if different species of pine seedlings could be relocated to higher altitudes (Castellanos-Acuña and others, 2015). Importantly, the authors found that an assisted upwards migration of $300 \mathrm{~m}$ in altitude appeared to be a viable strategy to accommodate effects of climate change projected for the year 2030. This is important because many of the sky-islands of the Southwest are isolated and the vegetation and wildlife communities are projected to be vulnerable to climate change (Coe and others, 2012; Kellermann and van Riper, 2015). Assisted relocations of vegetation into vulnerable areas could reduce distances between patches and possibly reduce the severity of projected effects.

In contrast to habitat that can be modified in a matter of hours through concerted efforts, developing plasticity in biological attributes may require evolutionary time frames (but see Wolak and others, 2010). With rare, thoroughly planned exceptions (for example, tuatara [Spenodon spp.]; Miller and others, 2012), there is presently no good support for the viability of assisted migrations as a panacea for conserving animal populations or even communities affected by climate change. We have a very limited understanding of the complexities and subtleties of variables important in niche occupancy and interactions with other species. As an example, the trophic implications of genetic differences between populations of the same species of plants occurring at different latitudes and altitudes have been shown to drive community biotic diversity, with important implications for selection of genetically appropriate source populations of plants for assisted migration (Grady and others, 2011; Ikeda and others, 2014). Additionally, there are more practical considerations implied by multiple well-documented failures of translocated individual and populations of reptiles to adapt to new surroundings (Sullivan and others, 2014). Additional research is required to improve the planning and outcome of assisted migrations for animals, especially given results of this study, which indicated tight associations between some birds and reptiles with certain plant species. 


\section{Conclusions}

Our sample size for birds and reptiles was relatively small but included species occupying a wide range of ecological niches, and our findings should be of interest and useful to wildlife agencies and forestry managers. There is growing demand for actionable science that provides governments and organizations with information and tools necessary to plan proactively for challenges posed by climate change. The A1B emission scenario modeled in this meta-analysis assumes that society will conduct business as usual until about mid-century, and then will begin to significantly reduce the global carbon footprint. There is little that can be done to change the amount of carbon dioxide in the atmosphere in the short term, making it more likely that the 2039 range projections will occur. However, the results suggest that proactive land management could lessen the severity of range contractions projected over the coming century for birds and reptiles. Additional work should be done to identify if the fragmentation metrics and biological attributes determined to be important in this analysis are equally influential in an independent study.

\section{Acknowledgments}

We appreciate the contributions of David Mattson, Cecil Schwalbe, and the partners of the U.S. Geological Survey National Climate Change and Wildlife Science Center stakeholders group in developing this project. We also thank the U.S. Geological Survey Southwest Climate Science Center for financial and logistical support, and their patience while we refined and completed the final report. Last, we thank Eben Paxton, Jeffrey Lovich, Barry Sinervo, and John Osias, for providing useful comments that greatly improved this paper.

\section{References Cited}

Anderson, D.R., and Burnham K.P., 2002, Avoiding pitfalls when using information-theoretic methods: Journal of Wildlife Management, v. 66, p. 912-918.

Anderson, R.S., Betancourt, J.L., Mead, J.I., Hevly, R.H., Adam, D.P., 2000, Middle- and lateWisconsin paleobotanic and paleoclimatic records from the southern Colorado Plateau, USA:

Palaeogeography, Palaeoclimatology, Palaeoecology, v. 155, p. 31-57.

Aragón, P., Rodríguez, M.A., Olalla-Tárraga, M.A., and Lobo, J.M., 2010, Predicted impact of climate change on threatened terrestrial vertebrates in central Spain highlights differences between endotherms and ectotherms: Animal Conservation, v. 13, p. 36-373.

Araújo, M.B., Thuiller, W., and Pearson, R.G., 2006, Climate warming and the decline of amphibians and reptiles in Europe:. Journal of Biogeography, v. 33, p. 1,712-1,728.

Arnold, T.W., 2010, Uninformative parameters and model selection using Akaike's Information Criterion: Journal of Wildlife Management, v. 74, p. 1,175-1,178.

Arundel, S., 2005, Using spatial models to establish climatic limiters of plant species' distributions: Ecological Modelling, v. 182, p. 159-181.

Balda, R.P., 2002, Pinyon jay (Gymnorhinus cyanocephalus), in Poole, A., ed., 2002, The birds of North America online: Ithaca New York, Cornell Lab of Ornithology, accessed August 29, 2013, at http://bna.birds.cornell.edu/bna/species/605, doi:10.2173/bna.605.

Barlow, J.C., Leckie, S.N., and Baril, C.T., 1999, Gray vireo (Vireo vicinior), in Poole, A., ed., 1999, The birds of North America online: Ithaca New York, Cornell Lab of Ornithology, accessed August 29, 2013, at http://bna.birds.cornell.edu/bna/species/447. doi:10.2173/bna.447. 
Barrows, C.W., 2011, Sensitivity to climate change for two reptiles at the Mojave-Sonoran Desert interface: Journal of Arid Environments, v. 75, p. 629-635.

Barrows, C.W., Hoines, J., Fleming, K.D., Vamstad, M.S., Murphy-Mariscal, M., Lalumiere, K., and Harding, M., 2014, Designing a sustainable monitoring framework for assessing impacts of climate change at Joshua Tree National Park, USA: Biodiversity and Conservation, v. 23, p. 3,263-3,285.

Barrows, C.W., and Murphy-Mariscal, M.L., 2012, Modeling impacts of climate change on Joshua trees at their southern boundary-How scale impacts predictions: Biological Conservation, v. 152, p. 2936.

Bateman, B.L., Murphy, H.T., Reside, A.E., Mokany, K., and VanDerWal, J., 2013, Appropriateness of full-, partial- and no-dispersal scenarios in climate change impact modelling: Diversity and Distributions, v. 19, p. 1,224-1,234.

Berry, K.H., Morafka, D.J., and Murphy, R.W. 2002, Defining the desert tortoise-Our first priority for a coherent conservation strategy: Chelonian Conservation and Biology, v. 4, p. 249-262.

Bonnet, X., Shine, R., and Lourdais, O., 2002, Taxonomic chauvinism: Trends in Ecology and Evolution, v. 17, p. 1-3.

Boykin, K.G., Thompson, B.C., Deitner, R.A., Schrupp, D., Bradford, D., O’Brien, L., Drost, C., Propeck-Gray, S., Rieth, W., Thomas, K., Kepner, W., Lowry, J., Cross, C., Jones, B., Hamer, T., Mettenbrink, C., Oakes, K.J., Prior-Magee, J., Schulz, K., Wynne, J.J., King, C., Puttere, J., Schrader, S., and Schwenke, Z., 2007, Predicted animal habitat distributions and species richness, chap. 3 of Prior-Magee, J.S., and others, eds., The Southwest regional gap analysis project final report: Moscow, Idaho, U.S. Geological Survey, Gap Analysis Program, p. 39-78.

Bradshaw, C.J.A., Brook, B.W., Delean, S., Fordham, D.A., Herrando- Pérez, S., Cassey, P., Early, R., Sekercioglu, C.H., and Araújo, M.B., 2014, Predictors of contraction and expansion of area of occupancy for British birds: Proceedings of the Royal Society B, v. 281, 20140744, at http://dx.doi.org/10.1098/rspb.2014.0744.

Breshears, D.D., Myers, O.B., Meyer, C.W., Barnes, F.J., Zou, C.B., Allen, C.D., McDowell, N.G., and Pockman, W.T., 2009, Tree die-off in response to global change-type drought-Mortality insights from a decade of plant water potential measurements: Frontiers in Ecology And the Environment, v. 7, p. 185-189.

Buckley, L.B., Hurlbert, A.H., and Jetz, W., 2012. Broad-scale ecological implications of ectothermy and endothermy in changing environments: Global Ecology and Biogeography, v. 21, p. 873-885.

Burnham, K.P., and Anderson, D.R., 2002, Model selection and multimodel inference-A practical information, theoretic approach, (2d ed.): New York, Springer-Verlag, 488 p.

Carfagno, G.L., and Weatherhead, P.J., 2006. Intraspecific and interspecific variation in use of forestedge habitat by snakes: Canadian Journal of Zoology, v. 84, p. 1,440-1,452.

Castellanos-Acuña, D., Lindig-Cisneros, R., and Sáenz-Romero, C., 2015, Altitudinal assisted migration of Mexican pines as an adaptation to climate change: Ecosphere, v. 6, p. 1-16, http://dx.doi.org/10.1890/ES14-00375.1.

Cicero, Carla, 2000, Juniper titmouse (Baeolophus ridgwayi), in Poole, A., ed., The Birds of North America Online: Cornell Lab of Ornithology, http://bna.birds.cornell.edu/bna/species/485b.

Clusella-Trullas, S., Blackburn, T.M., and Chown, S.L., 2011, Climatic predictors of temperature performance curve parameters in ectotherms imply complex responses to climate change: The American Naturalist, v. 177, p. 738-751.

Coe, S.J., Finch, D.M., and Friggens, M.M., 2012, An assessment of climate change and the vulnerability of wildlife in the Sky Islands of the Southwest: U.S. Forest Service, Rocky Mountain Research Station, Fort Collins, Colorado, General Technical Report RMRS-GTR-273, 208 p. 
Cole, K.L., 1985, Past rates of change, species richness, and a model of vegetational inertia in the Grand Canyon, Arizona: The American Naturalist, v. 125, p. 289-303.

Cole, K.L., 2010, Vegetation response to early Holocene warming as an analog for current and future changes: Conservation Biology, v. 24, p. 29-37.

Cole, K.L., Ironside, K.E., Arundel, S., Duffy, P., and Shaw, J., 2008, Modeling future plant distributions on the Colorado Plateau-An example using Pinus edulis, in van Riper, C., and Sogge, M., eds., The Colorado Plateau III-Cultural, biological, and physical research: Tucson, University of Arizona Press, 256 p.

Cole, K.L., Ironside, K., Eischeid, J., Garfin, G., Duffy, P.B., and Toney, C., 2011, Past and ongoing shifts in Joshua tree distribution support future modeled range contraction: Ecological Applications, v. 21, p. 137-149.

Cole, K.L., Fischer, J., Ironside, K., Mead, J.I., and Koehler, P., 2013, The biogeographic histories of Pinus edulis and Pinus monophylla over the last 50,000 years: Quaternary International, v. 310, p. 96-110.

Collins, W.D., Bitz, C.M., Blackmon, M.L., Bonan, G.B., Bretherton, C.S., Carton, J.A., Chang, P., Doney, S.C., Hack, J.J., Henderson, T.B., Kiehl, J.T., Large, W.G., McKenna, D.S., Santer, B.D., and Smith, R.D., 2006, The Community Climate System Model Version 3 (CCSM3): Journal of Climate, v. 19, p. 2,122-2,142.

Comer, P J., Young, B., Schulz, K., Kittel, G., Unnasch, B., Braun, D., Hammerson, G., Smart, L., Hamilton, H., Auer, S., Smyth, R., and Hak, J., 2012, Climate change vulnerability and adaptation strategies for natural communities-Piloting methods in the Mojave and Sonoran deserts: Report to the U.S. Fish and Wildlife Service by NatureServe, Arlington, Virginia, 62 p. + appendixes.

Consortium of California Herbaria, 2013, CCH search: website accessed September 5, 2013, at http://ucjeps.berkeley.edu/consortium/.

Daly, C., Neilson, R.P., and Phillips, D.L., 1994, A statistical-topographic model for mapping climatological precipitation over mountainous terrain: Journal of Applied Meteorology, v. 33, p. 140158.

Davis, M.B., 1981, Quaternary history and the stability of forest communities, in West, D.G., Shugart, H.H., and Botkin, D.B., eds., Forest succession-Concepts and application: New York, SpringerVerlag, p. 132-153.

Dawson, T.P., Jackson, S.T., House, J.I., Collin Prentice, I., and Mace, G.M., 2011, Beyond predictions - Biodiversity conservation in a changing climate: Science, v. 332, p. 53-58.

Diffenbaugh, N.S., Giorgi, F., and Pal, J.S., 2008, Climate change hotspots in the United States: Geophysical Research Letters, v. 35, p. L16709.

Diffenbaugh, N.S., Pal, J.S., Trapp, R.J., and Giorgi, F., 2005, Fine-scale processes regulate the response of extreme events to global climate change: Proceedings of the National Academy of Sciences, v. 102, p. 15,774-15,778.

Dobbs, R.C., Martin, T.E., and Conway, C.J., 1997, Williamson's sapsucker, in Poole, A., ed., The birds of North America online: Ithaca, New York, Cornell Lab of Ornithology, accessed August 29, 2013, at http://bna.birds.cornell.edu/bna/species/285.

Edwards, T., Stitt, E.W., Schwalbe, C.R., and Swann, D.E., 2004, Natural history notes_Gopherus agassizii (Desert Tortoise) —Movement: Herpetological Review, v. 35, p. 381-382.

Egan, J.P., 1975, Signal detection theory and ROC analysis-Series in cognition and perception: New York, Academic Press, 277 p.

Elith, J., Kearney, M., Phillips, S., 2010, The art of modeling range-shifting species: Methods in Ecology and Evolution, v. 1, p. 330-342. 
Elith, J., Phillips, S.J., Hastie, T., Dudík, M., Chee, Y.E., and Yates, C.J., 2011, A statistical explanation of MaxEnt for ecologists: Diversity and Distributions, v. 17, p. 43-57.

Environmental Systems Research Institute, 1992, Cell-based modeling with GRID (2d ed.): Redlands, California, Environmental Systems Research Institute, 267 p.

Fernandez-Duque, E., and Valeggia, C., 1994, Meta-analysis-A valuable tool in conservation research: Conservation Biology, v. 8, p. 555-561.

Forest Inventory and Analysis (FIA) DataMart, 2008, FIADB version 3.0, accessed on August 9, 2008, at http://fiatools.fs.fed.us/fiadb-downloads/datamart.html.

Friggens, M., Bagne, K., Finch, D., Falk, D., Triepke, J., and Lynch, A., 2013, Review and recommendations for climate change vulnerability assessment approaches with examples from the Southwest: U.S. Forest Service, Rocky Mountain Research Station, Fort Collins, Colorado, General Technical Report RMRS-GTR-309, 106 p.

Gardali, T., Seavy, N.E., DiGaudio, R.T., and Comrack, L.A., 2012, A climate change vulnerability assessment of California's at-risk birds: PLoS ONE, v. 7, p. e29507, doi:10.1371/journal.pone.0029507

Garfin, G.M., Eischeid, J.K., Lenart, M.T., Cole, K.L., Ironside, K., and Cobb, N., 2010, Downscaling climate projections in topographically diverse landscapes of the Colorado Plateau in the arid southwestern United States, in van Riper, C., III, Wakeling, B.F., and Sisk, T.D., eds., The Colorado Plateau IV_-Shaping conservation through science and management: Tucson, University of Arizona Press, p. 22-43.

Godsoe, W., 2010, Regional variation exaggerates ecological divergence in niche models: Systematic Biology, v. 59, p. 298-306.

Global Biodiversity Information Facility, 2013, GBIF website accessed September 12, 2013, at http://www.gbif.org.

Grady, K.C., Ferrier, S.M., Kolb, T.E., Hart, S.C., Allan, G.J., and Whitham, T.G., 2011, Genetic variation in productivity of foundation riparian species at the edge of their distribution-Implications for restoration and assisted migration in a warming climate: Global Change Biology, v. 17, p. 3,7243,735 .

Grinnell, J., 1917. Field tests of theories concerning distributional control: The American Naturalist, v. 51, p. 115-128.

Guisan, A., and Thuiller, W., 2005, Predicting species distribution-Offering more than simple habitat models: Ecology Letters, v. 8, p. 993-1,009.

Guthery, F.S., Brennan, L.A., Peterson, M.J., and Lusk, J.J., 2005, Information theory in wildlife science-Critique and viewpoint: Journal of Wildlife Management, v. 69, p. 457-465.

Guzy, M.J., and Lowther, P.E., 2012, Black-throated Gray Warbler (Setophaga nigrescens), in Poole, A., ed., The Birds of North America Online: Ithaca, Cornell Lab of Ornithology, http://bna.birds.cornell.edu/bna/species/319.

Haddad, N.M., Brudvig, L.A., Colbert, J., Davies, K.F., Gonzalez, A., Holt, R.D., Lovejoy, T.E., Sexton, J.O., Austin, M.P., Collins, C.D., Cook, W.M., Damschen, E.I., Ewers, R.M., Foster, B.L., Jenkins, C.N., King, A.J., Laurance, W.F., Levey, D.J., Margules, C.R., Melbourne, B.A., Nicholls, A.O., Orrock, J.L., Song, D., and Townshend, J.R., 2015, Habitat fragmentation and its lasting impact on earth's ecosystems: Science Advances, v, 1, p. e1500052.

Hammerson, G.A., 2007, Sceloporus graciosus - The International Union for Conservation of Nature Red List of Threatened Species 2007: The International Union for Conservation of Nature Web site, accessed October 2, 2015, at e.T64106A12743889.http://dx.doi.org/10.2305/IUCN.UK.2007.RLTS.T64106A12743889.en. 
Hastie, T., Tibshirani, R., and Friedman, J.H., 2009, The elements of statistical learning-Data mining, inference, and prediction: New York, Springer Verlag, $763 \mathrm{p}$.

Holling, C.S., 1992, Cross-scale morphology, geometry and dynamics of ecosystems: Ecological Monographs, v. 62, p. 447-502.

Hosmer, D.W., and Lemeshow, S., 1989, Applied logistic regression (1st ed.): New York, Wiley, 392 p. Hosmer, D.W., and Lemeshow, S., 2000, Applied logistic regression (2d ed.): New York, Wiley, 375 p.

Ikeda, D.H., Bothwell, H.M., Lau, M.K., O'Neill, G.A., Grady, K.C., and Whitham, T.G., 2014, A genetics-based Universal Community Transfer Function for predicting the impacts of climate change on future communities: Functional Ecology, v. 28, p. 65-74.

Iliff, M., Salas, L., Inzunza, E.R., Ballard, G., Lepage, D., and Kelling, S., 2009, The avian knowledge network-A partnership to organize, analyze, and visualize bird observation data for education, conservation, research, and land management: Proceedings of the Fourth International Partners in Flight Conference-Tundra to tropics, February 13-16, 2008, McAllen, Texas, p. 365-373.

Ironside, K.E., 2006, Climate change research in national parks-Paleoecology, policy, and modeling the future: Flagstaff, Northern Arizona University, M.S. thesis.

Johns, T.C., Durman, C.F., Banks, H.T., Roberts, M.J., McLaren, A.J., Ridley, J.K., Senior, C.A., Williams, K.D., Jones, A., Rickard, G.J., Cusack, S., Ingram, W.J., Crucifix, M., Sexton, D.M.H., Joshi, M.M., Dong, B-W., Spencer, H., Hill, R.S.R., Gregory, J.M., Keen, A.B., Pardaens, A.K., Lowe, J.A., Bodas-Salcedo, A., Stark, S. and Searl, Y., 2005, The new Hadley Centre climate model HadGEM1: Evaluation of coupled simulations: Journal of Climate, v. 19, p. 1,327-1,353.

Johnson, D.H., 1980, The comparison of usage and availability measurements for evaluating resource preference: Ecology, v. 61, p. 65-71.

Jones, L.L., and Lovich, R.E., eds., 2009, Lizards of the American Southwest-A photographic field guide: Tucson, Arizona, Rio Nuevo Publishers.

Jungclaus, J.H., Keenlyside, N., Botzet, M., Haak, H., Luo, J.-J., Latif, M., Marotzke, J., Mikolajewicz, U., and Roeckner, E., 2006, Ocean circulation and tropical variability in the AOGCM ECHAM5/MPIOM: Journal of Climate, v. 19, p. 3,952-3,972.

Keating, K.A., and Cherry, S., 2004, Use and interpretation of logistic regression in habitat selection studies: Journal of Wildlife Management, v. 68, p. 774-789.

Kellermann, J.L., and van Riper, C., III, 2015, Spatiotemporal patterns of bird migration and responses to interannual climatic variation across elevational gradients of the Madrean Sky Island Archipelago: Oecologia, v. 178, no. 4, p. 1,227-1,238.

Kingery, H.E., and Ghalambor, C.K., 2001, Pygmy nuthatch (Sitta pygmaea), in Poole, A., ed., The birds of North America online: Ithaca, New York, Cornell Lab of Ornithology, accessed August 29, 2013, at http://bna.birds.cornell.edu/bna/species/567.doi:10.2173/bna.567.

LANDFIRE Reference Database, 2007, Version 0.32: Missoula, Montana, U.S. Department of Agriculture, U.S. Forest Service, www.landfire.gov.

Lawing, A.M., and Polly, P.D., 2011, Pleistocene climate, phylogeny, and climate envelope modelsAn integrative approach to better understand species' response to climate change: PLoS ONE, v. 6, no. 12, e28554, doi:10.1371/journal.pone.0028554.

Lovich, J.E., and Ennen, J.R., 2013, A quantitative analysis of the state of knowledge of turtles of the United States and Canada: Amphibia-Reptilia, v. 34, p. 11-23.

Lovich, J.E., Yackulic, C.B., Freilich, J., Agha, M., Austin, M., Meyer, K.P., Arundel, T.R., Hensen, J., Vamstad, M.S., and Root, S.A., 2014, Climatic variation and tortoise survival-Has a desert species met its match?: Biological Conservation, v. 169, p. 214-224. 
Liu, C., Berry, P.M., Dawson, T.P., and Pearson, R.G., 2005, Selecting thresholds of occurrence in the prediction of species distributions: Ecography, v. 28, p. 385-393.

Mackey, B.G., and Lindenmayer, D.B., 2001, Towards a hierarchical framework for modelling the spatial distribution of animals: Journal of Biogeography, v. 28, p. 1,147-1,166.

McGarigal K., and Cushman, S.A., 2002, Comparative evaluation of experimental approaches to the study of habitat fragmentation effects: Ecological Applications, v. 12, p. 335-345.

McGarigal, K., Cushman, S.A., Neel, M.C., and Ene, E., 2002, FRAGSTATS - Spatial pattern analysis program for categorical maps: Amherst, University of Massachusetts, computer software program produced by the authors, accessed April 20, 2015, at

http://www.umass.edu/landeco/research/fragstats/fragstats.html.

McGarigal, K., and Marks, B.J., 1995, FRAGSTATS — Spatial pattern analysis program for quantifying landscape structure: Portland, Oregon, U.S. Forest Service, Pacific Northwest Research Station, General Technical Report PNW-GTR-351, 122 p.

McLachlan, J.S., Clark, J.S., and Manos, P.S. 2005, Molecular indicators of tree migration capacity under rapid climate change: Ecology, v. 86, p. 2,088-2,098.

Mearns, L.O., Gutowski, W., Jones, R., Leung, L.-Y., McGinnis, S., Nunes, A.M.B., and Qian, Y., 2009, A regional climate change assessment program for North America: Eos, Transactions American Geophysical Union, v. 90, p. 311-312.

Meehl, G.A., Covey, C., Taylor, K.E., Delworth, T., Stouffer, R.J., Latif, M., McAvaney, B., and Mitchell, J.F.B., 2007, The WCRP CMIP3 multi-model dataset-A new era in climate change research: Bulletin of the American Meteorological Society, v. 88, p. 1,383-1,394.

Millennium Ecosystem Assessment, 2005, Ecosystems and human well-being-Biodiversity synthesis: Washington, D.C., World Resources Institute, 86 p.

Miller, K.A., Miller, H.C., Moore, J.A., Mitchell, N.J., Cree, A., Allendorf, F.W., Sarre, S.D., Keall, S.H., and Nelson, N.J., 2012, Securing the demographic and genetic future of tuatara through assisted colonization: Conservation Biology, v. 26, p. 790-798.

Murphy, R.W., Berry, K.H., Edwards, T., Leviton, A.E. Lathrop. A., and Riedle, J.D., 2011, The dazed and confused identity of Agassiz's land tortoise, Gopherus agassizii (Testudines, Testudinidae) with the description of a new species, and its consequences for conservation. ZooKeys v. 113, p. 39-71.

Nakicenovic, N., and Swart, R., eds., 2000, Special report on emissions scenarios-Intergovernmental Panel on Climate Change: Cambridge, United Kingdom, Cambridge University Press, 599 p., http://www.grida.no/climate/ipcc/ emission/.

National Audubon Society, 2013, Developing a management model of the effects of future climate change on species-A tool for the landscape conservation cooperatives: (written communication: unpublished report prepared for the U.S. Fish and Wildlife Service, 244 p.).

National Audubon Society, 2014, Audubon's bird and climate change report-A primer for practitioners (version 1.2): New York, National Audubon Society, 35 p.

North American Bird Conservation Initiative, 2014, The state of the birds report 2014: U.S. Department of Interior, $16 \mathrm{p}$.

Notaro, M., Mauss, A., and Williams, J.W., 2012, Projected vegetation changes for the American Southwest —Combined dynamic modeling and bioclimatic-envelope approach: Ecological Applications, v. 22, 1,365-1,388.

Nowak, E.M., 2009, Ecology and management of venomous reptilian predators: Flagstaff, Northern Arizona University, Ph.D. dissertation. 
Nowak, E.M., Amarello, M., and Smith, J.J., in press, Arizona Black Rattlesnake (Crotalus cerberus), in Schuett, G.W., Feldner, M.J., Reiserer, R.S., and Smith, C.F., eds., The rattlesnakes of Arizona: Rodeo, New Mexico, Eco Publishing.

Olson, C.R., and Martin, T.E., 1999, Virginia's warbler (Oreothlypis virginiae), in Poole, A., ed., The birds of North America online: Ithaca, New York, Cornell Lab of Ornithology, accessed August 29, 2013, at http://bna.birds.cornell.edu/bna/species/477, doi:10.2173/bna.477.

Pachauri, R.K, and Reisinger, A., eds., 2007, Climate change 2007-Synthesis report - Contribution of working groups I, II and III to the fourth assessment report of the Intergovernmental Panel on Climate Change: Geneva, Switzerland, Intergovernmental Panel on Climate Change, $104 \mathrm{p}$.

Pacifici, M., Foden, W.B., Visconti, P., Watson, J.E.M., Butchart, S.H.M., Kovacs, K.M., Scheffers, B.R., Hole, D.G., Martin, T.G., Akçakaya, H.R., Corlett, R.T., Huntley, B., Bickford, D., Carr, J.A., Hoffmann, A.A., Midgley, G.F., Pearce-Kelly, P., Pearson, R.G., Williams, S.E., Willis, S.G., Young, B., and Rondini, C., 2015, Assessing species vulnerability to climate change: Nature Climate Change, v 5, p. 215-224.

Pearson, R.G., and Dawson, T.P., 2003, Predicting the impacts of climate change on the distribution of species-Are bioclimate envelope models useful?: Global Ecology and Biogeography, v. 12, p. 361-371.

Peduzzi, P., Concato, J., Kemper, E., Holford, T.R., and Feinstein, A.R., 1996, A simulation study of the number of events per variable in logistic regression analysis: Journal of Clinical Epidemiology, v. 49, p. 1,373-1,379.

Persons, T.B., and Nowak, E.M., 2006a, Inventory of amphibians and reptiles at Death Valley National Park: U.S. Geological Survey Open-File Report 2006-1233, 32 p.

Persons, T.B., and Nowak, E.M., 2006b. Inventory of amphibians and reptiles in southern Colorado Plateau National Parks - Final Report: U.S. Geological Survey, Southwest Biological Science Center, Flagstaff, Arizona, 73 p.

Persons, T.B., and Nowak, E.M., 2007, Inventory of amphibians and reptiles at Mojave National Preserve: U.S. Geological Survey Open-File Report 2007-1109, 72 p.

Persons, T.B., Nowak, E.M., and Hillard, S., 2006, Inventory of amphibians and reptiles at Manzanar National Historic Site, California: U.S. Geological Survey Open-File Report 2006-1232, 31 p.

Phillips, S.J., Anderson, R.P., and Schapire, R.E., 2006, Maximum entropy modeling of species geographic distributions: Ecological Modelling, v. 190, p. 231-259.

Phillips, S.J., and Dudík, M., 2008, Modeling of species distributions with Maxent-New extensions and a comprehensive evaluation: Ecography, v. 31, p. 161-175.

Phillips, S.J., Dudík, M., Elith, J., Graham, C.H., Lehmann, A., Leathwick, J., and Ferrier, S., 2009, Sample selection bias and presence-only distribution models-Implications for background and pseudo-absence data: Ecological Applications, v. 19, p. 181-197.

Reynolds, T.D., Rich, T.D., and Stephens, D.A., 1999, Sage thrasher, in Poole, A., ed., The birds of North America online: Ithaca, New York, Cornell Lab of Ornithology, accessed August 29, 2013, at http://bna.birds.cornell.edu/bna/species/463.

Rios, N.E., and Bart, H.L., 2010, GEOLocate (version 3.22): Belle Chasse, Louisiana, Tulane University Museum of Natural History software application.

Rowland, E.L., Davison, J.E., and Graumlich, L.J., 2011, Approaches to evaluating climate impacts on species-A guide to initiating the adaptive planning process: Environmental Management, v. 47, p. 322-337.

Rugiero, L., Milana, G., Petrozzi, F., Capula, M., and Luiselli, L. 2013, Climate-change-related shifts in annual phenology of a temperate snake during the last 20 years: Acta Oecologica, v. 51, p. 42-48. 
Sauer, J.R., Hines, J.E., Fallon, J.E., Pardieck, K.L., Ziolkowski, D.J., Jr., and Link, W.A., 2014, The North American breeding bird survey, results and analysis 1966-2013, version 01.30.2015: U.S. Geological Survey Patuxent Wildlife Research Center, Laurel, Maryland.

Seager, R., Ting, M., Held, I., Kushnir, Y., Lu, J., Vecchi, G., Huang, H., Harnik, N., Leetma, A., Lau, N., Li, C., Velez, J., and Naik, N., 2007, Model projections of an imminent transition to a more arid climate in southwestern North America: Science, v. 316, p. 1,181-1,184.

Sinervo, B., and others, 2010, Erosion of lizard diversity by climate change and altered thermal niches: Science, v. 328, p. 894-899.

Sohl, T.L., 2014, The relative impacts of climate and land-use change on conterminous United States bird species from 2001 to 2075: PLoS ONE, v. 9, e112251 doi:10.1371/journal.pone.0112251.

Solomon, S., Qin, D., Manning, M., Chen, Z., Marquis, M., Averyt, K.B., Tignor, M., and Miller H.L., eds., 2007, Contribution of working group I to the fourth assessment report of the Intergovernmental Panel on Climate Change, in Intergovernmental Panel on Climate Change, Climate change-The physical science basis, 2007: Cambridge, United Kingdom and New York, Cambridge University Press.

Southwest Environmental Information Network, 2013, SEINet Web site, accessed September 12, 2013, at http://swbiodiversity.org/seinet/projects/index.php.

Southwest ReGAP project, 2013, ReGAP Website accessed September 12, 2013, at http://earth.gis.usu.edu/swgap/trainingsites.html.

Story, M., and Congalton, R.G., 1986, Accuracy assessment-A user's perspective: Photogrammatry Engineering and Remote Sensing, v. 52, p. 397-399.

Sullivan, B.K., Nowak, E.M., and Kwiatkowski, M.A., 2014, Problems with mitigation translocation of herpetofauna: Conservation Biology, v. 29, p. 12-18.

Sullivan, B.L., Wood, C.L., Iliff, M.J., Bonney, R.E., Fink, D., and Kelling, S., 2009, eBird-A citizenbased bird observation network in the biological sciences: Biological Conservation, v. 142, p. 2,2822,292 .

Thomas, K., Keeler-Wolf, T., and Thorne, J., 2002, Central Mojave field data-A digital database: U.S. Geological Survey, Forest and Rangeland Ecosystem Science Center, Colorado Plateau Field Station, Flagstaff, Arizona, USA.

Uchytil, R.J., 1991, Picea engelmannii, in Fire Effects Information System (FEIS): U.S. Forest Service database, Rocky Mountain Research Station, Fire Sciences Laboratory, accessed November 4, 2010 , at http://www.fs.fed.us/database/feis/.

U.S. Fish and Wildlife Service, 2010, Rising to the urgent challenge-Strategic plan for responding to accelerating climate change: U.S. Fish and Wildlife Service, $32 \mathrm{p}$.

VanDerWal, J., Shoo, L.P., Graham, C., and Williams, S.E., 2009, Selecting pseudo-absence data for presence-only distribution modeling-How far should you stray from what you know?: Ecological Modelling, v. 220, p. 589-594.

van Riper, C., III., Hatten, J.R., Giermakowski, J.T., Mattson, D., Holmes, J.A., Johnson, M.J., Nowak, E.M., Ironside, K., Peters, M., Heinrich, P., Cole, K.L., Truettner, C., and Schwalbe, C.R., 2014, Projecting climate effects on birds and reptiles of the southwestern United States: U.S. Geological Survey Open-File Report 2014-1050, 100 p., http://pubs.usgs.gov/ofr/20141050/.

Warren, D.K., 1979, Precipitation and temperature as climatic determinants of the distribution of Fouquieria columnaris: Massachusetts, Walden University, Ph.D. dissertation, 133 p.

Warren, D.L., Glor, R.E., and Turelli, M., 2010, ENMTools-A toolbox for comparative studies of environmental niche models: Ecography, v. 33, p. 607-611. 
Warren, D.L., and Seifert, S.N., 2011, Ecological niche modeling in Maxent-The importance of model complexity and the performance of model selection criteria: Ecological Applications, v. 21, p. 335342.

Williams, A.P., Allen, C.D., Macalady, A.K., Griffin, D., Woodhouse, C.A., Meko, D.M. Swetnam, T.W., Rauscher, S.A., Seager, R., Grissino-Mayer, H.D., Dean, J.S., Cook, E.R., Gangodagamage, C., Cai, M., and McDowell, N.G., 2012, Temperature as a potent driver of regional forest drought stress and tree mortality: Nature Climate Change, http://dx.doi.org/10.1038/nclimate1693.

Wolak, M.E., Gilchrist, G.W., Ruzicka, V.A., Nally, D.M., and Chambers, R.M., 2010, A contemporary, sex-limited change in body size of an estuarine turtle in response to commercial fishing: Conservation Biology, v. 24, p. 1,268-1,277.

Wright, A.N., Hijmans, R.J., Schwartz, M.W., and Shaffer, H.B., 2015, Multiple sources of uncertainty affect metrics for ranking conservation risk under climate change: Diversity and Distributions, v. 21, p. 111-122.

Xu, X., Zhou, Z., Dudley, R., Mackem, S., Chuong, C.M., Erickson, G.M., and Varricchio, D.J., 2014, An integrative approach to understanding bird origins: Science, v. 346, 1253293 p. 1-10.

Young, B.E., Dubois, N.S., and Rowland, E.L., 2015, Using the climate change vulnerability index to inform adaptation planning-Lessons, innovations, and next steps: Wildlife Society Bulletin, v. 39, p. 174-181, doi: 10.1002/wsb.478.

Zar, J.H., 1984, Biostatistical analysis (2d ed.): Englewood Cliffs, New Jersey, Prentice-Hall. 


\section{Appendix 1. Bird and Reptile Distribution Data and Processing Steps (Modified from Van Riper and others, 2014, with Permission)}

\section{Overview}

Ascertaining species presence or absence at the grain of $16 \mathrm{~km}^{2}$ (4-km cells) over several decades is too coarse a scale to allow incorporation of most demographic processes, including birth, death, immigration, and emigration rates, as well as ultimate metrics such as density, and physiological envelopes of species. Nonetheless, we expected coarse-grained presence to be significantly correlated with all of these processes at broader scales; that is, we expected to detect a species where densities were higher, and where birth and immigration rates were correspondingly higher and death rates lower. Even so, our model results do not support or inform management at scales finer than $16 \mathrm{~km}^{2}$.

We obtained species distribution data for 15 bird species and 16 reptile species from national repositories and museum records. We acquired and processed three types of bird location data-(1) presence only, (2) presence and absence, and (3) polygonal range maps. Species presence and absence data were acquired from the Avian Knowledge Network (AKN) Web site (Avian Knowledge Network, http://www.avianknowledge.net). The AKN assembles locational observations of birds from bird monitoring, bird banding, and broad-scale citizen-based bird surveillance programs (Sauer and others, 2014).

\section{Bird Distribution Data}

We acquired presence data by species for 1990-July 2009 for the entire United States. We first imported these data into Microsoft Access ${ }^{\circledR}$ databases from downloaded ASCII text files. Once imported, these data were manipulated in Access ${ }^{\circledR}$ to remove unwanted attributes and records identified on the basis of project specifics. We then converted the presence databases into Environmental Systems Research Institute (ESRI) ArcGIS ${ }^{\circledR}$ layers. We then analyzed the geographical information system (GIS) layers to remove records, such as those that were outside the project study area, from unwanted collections, and outside the species breeding dates. Birds of North America accounts (Dobbs and others, 1997; Barlow and others, 1999; Olson and Martin, 1999; Reynolds and others, 1999; Kingery and Ghalambor, 2001; Balda, 2002) were used to estimate the breeding season for each bird species. We acquired and processed absence observation data similarly to the presence observations, although the presence-absence data had to be acquired as sample events. The sample event data included records for all species in the United States from 1990 to July 2009. Sample event data were all analyzed within ArcGIS $^{\circledR}$ to produce absence observation events for each species. 
NatureServe collects, manages, and disseminates detailed local information on plants, animals, and ecosystems. We acquired species range maps from the NatureServe Web site (NatureServe, http://www.natureserve.org/explorer/). Range maps were gathered by taxonomic family and extracted as ESRI shapefiles for each desired species. We analyzed the shapefiles within ArcGIS ${ }^{\circledR}$ to remove all but each species breeding range. We further used ArcGIS ${ }^{\circledR}$ to generate 1-degree buffers around breeding range polygon(s), and then used these buffered ranges to discard all observations of the corresponding species that were outside our study area. All three data types (presence and absence observation events, and range maps) were delivered for analysis in shapefile format with a standard spatial reference of Geographic Coordinate System, World Geodetic System (1972).

\section{Reptile Distribution Data}

Records of occurrence for our selected taxa in the Western United States included data collected between 1852 and 2010, although most records represent records collected after 1980. We were not able to confirm the taxonomic determination of each specimen or observation, but we did scrutinize individual data points that we deemed suspect because of their geographic position and excluded such uncertain data from analyses. Because much of the location information associated with obtained data was only descriptive (that is, not geo-referenced), we assigned geographic coordinates either automatically through specialized programs (GEOLocate, version 3.21; Rios and Bart, 2010) or manually by finding the location using Google Earth ${ }^{\mathrm{TM}}$ (Google Inc., Mountain View, California) and other resources within a geographical information system (ArcGIS ${ }^{\circledR}$, version 10, ESRI, Inc., Redlands, California). In cases where coordinates were generated by software (unsupervised), we reviewed the correspondence of individual sets of coordinates to the locality description. We reduced the number of records to 1 per grid cell (about $16 \mathrm{~km}^{2}$ ) to minimize sampling bias, which is especially important for correlative modeling (Phillips and others, 2009). We registered all georeferenced point-range data for reptiles by cells that were used for our spatial modeling. Once registered, each grid cell containing one or more presence locations constituted our record of presences for individual species. This process substantially reduced the number of presence observations used for spatial modeling. 


\section{Appendix 2. Plant Distributions, Processing Steps, and Modeling Methods- Example Using Pinyon Pine (Pinus edulis)}

\section{Overview-Conceptual Underpinnings}

The early work of Alexander von Humboldt in the 17th century demonstrated the primary role of climatic conditions on the distribution of plant species and patterns in vegetation. A seminal work by Grinnell (1917) in the formation of modern ecological niche theory also suggested that the broad ranges of species are limited by physiological and behavioral responses to temperature and precipitation. Although ecological niche theory has advanced over the last century, the general notion of climate playing an important role in the broad scale ranges of species has held through time. Many ecologists now suggest that there is a general hierarchy of scaled factors that affect species occurrence (Johnson, 1980; Holling, 1992; Mackey and Lindenmayer, 2001; Pearson and Dawson, 2003; Guisan and Thuiller, 2005). At the coarsest spatial and temporal resolution, that of the geographic range of a species, the potential for a species to be present or absent relates to abiotic factors such isothermic regions. Species occurrence within its potential range is further limited by its ability to disperse into suitable environments, resource availability such as soil nutrients, past history of disturbance events, and biotic interactions such as competition. As one modulates the bioclimatic range of an organism by accounting for dispersal, disturbance, and biotic interactions, the closer to the realized distribution of the organism one becomes (Guisan and Thuiller, 2005).

We identify suitable climatic environments for various common plant species to project potential changes in the geographic distribution of suitable climate space under various 21 st-century climate change scenarios forced by projected anthropogenic emissions. Although climatic controls on the distribution of organisms are considered coarse, they also are assumed here to be of primary importance. Without the proper climatic regime to support the potential occurrence of a species, all other factors become moot. Many of the factors included in the following models are hypothesized to be directly linked to physiological tolerances, such as low winter temperatures related to the average frost tolerance of a plant species. These factors also are assumed to be relatively static over time; for example, the average frost tolerance of a certain species is not expected to change significantly within the next century.

The scale of the modeling effort presented here is considered global, meso-scaled (Mackey and Lindenmayer, 2001) where the factors used to predict the potential distribution of species is modulated by latitudinal and seasonal atmospheric circulation patterns and how these interact with land surface topology such as mountain ranges. Changes in these large spatial scale patterns also are assumed to occur on a large temporal scale from decades to centuries. Likewise, the ability of a species to shift its geographic range also is assumed to be a relatively slow process for most long-lived plant species included here. The goal of this modeling effort is to identify areas where it is climatically suitable for a plant species to survive and successfully reproduce. The abiotic climatic factors selected are thought to control the broad geographic range of the species and also to identify the potential range. Because these macroscale predictors are the only factors within this scope of work, we do not expect the models to predict fine-scale regional occurrences precisely or to represent the realized distribution of the species. 
Many other factors come into play when trying to distinguish species occurrence within regions and between sites. Because many of these other limiting factors can be dynamic over time, they can result in including false assumptions when empirical modeling techniques are used because a dynamic factor may be treated as static over time. For example, during the latter part of the Pleistocene on the southern Colorado Plateau, Engelmann spruce (Picea engelmannii) was a dominant tree across the landscape, likely occurring across several landforms from valley bottoms to steep hillsides (Anderson and others, 2000). Today Engelmann spruce on the Colorado Plateau is restricted to cold-wet microclimates provided by cold air drainages, streams, and mountainous terrain at tree line (Uchytil, 1991). Although cold air drainages and extreme topography could be included in a model to better predict its modern-day occurrence on the Colorado Plateau, this model may be erroneous when applied to a different region or time period where cold wet climates are available on other sorts of topographic features, as was the case in the past.

\section{Plant Distributions}

\section{Occurrence Data}

Occurrence data for the presence and absence of tree species were obtained from the Forest Inventory and Analysis (FIA) (2008), by downloading the TREE and PLOT tables for all states combined. Non-forest, phase 1, plots were included as absence data for tree species. For non-tree species, we relied on FIA subplot data, but public availability of this data at the time was limited to a few areas. In addition to FIA, data sources of plant presence and absences included the LANDFIRE Reference Database (2007), the Central Mojave field data (Thomas and others, 2002), the Southwest ReGAP project (2013), the participants of the Consortium of California Herbaria (2013), the Global Biodiversity Information Facility (2013), and the Southwest Environmental Information Network (2013).

\section{Range Mapping}

We used two different methods to develop range maps of current distributions for plant species that potentially were important to birds and reptiles. Our use of methods depended on the spatial distribution of occurrence records. For plant species with sparse or patchily distributed occurrence data, we used heads-up digitizing that used information on distribution by altitude, occurrence by plant community types, and expert opinion. For species that had been systematically and intensely sampled, as in the Forest Inventory and Analysis (FIA) databases, we used ArcGIS ${ }^{\circledR} 9.3$ Geostatistical Analyst to interpolate presence/absence locations across the FIA grid, which is sampled about every $5 \mathrm{~km}$. We interpolated using radial splines with the neighborhood set to 8-12 observations in all directions. We determined that a threshold of 0.10 was optimal for distinguishing between presence and absence and exported the results as a raster at the same resolution and extent as the climate data $(4 \mathrm{~km})$. 


\section{Suitable Climate Modeling}

Observed 2.5-minute resolutions $(4 \times 4 \mathrm{~km})$ climate grids were obtained from the PRISM Group Web site for total monthly precipitation, mean maximum monthly temperature, and mean minimum monthly temperature (PRISM Climate Group, Oregon State University, http://prism.oregonstate.edu, created February 4, 2004). The time period of 1950-1999 was selected for training models to capture a range of climatic conditions that occurred during periods of known recruitment, growth, and population persistence despite some drought dieback during the late-1950s and late-1990s. We do not identify explicitly the conditions that produce high levels of drought mortality such as those that occurred during 2002-03 (Breshears and others 2009). Mean maximum monthly temperature and mean minimum monthly temperature were averaged to calculate mean monthly temperature to correspond to the mean monthly temperatures provided in the IPCC (Intergovernmental Panel on Climate Change) AR4 (Fourth Assessment Report) GCM (general circulation model) simulation results (Intergovernmental Panel on Climate Change, 2007). IPCC AR4 GCM results were obtained from the World Climate Research Programme (WCRP) Coupled Model Intercomparison Project phase 3 (CMIP3) multi-model dataset (Meehl and others 2007). Details on the models and their configurations are available at http://wwwcmdi.llnl.gov/ipcc/model_documentation/ipcc_model_documentation.php. For a given time period, we averaged the mean monthly precipitation over the time period, but for mean monthly temperature, we used the minimum and maximum mean monthly temperatures over the time period to capture the effects of extreme events (Diffenbaugh and others 2005).

Previously we analyzed, individually, the 22 models (48 simulations) that are forced with estimated greenhouse gas and aerosol changes from the late 19th century through 1999, and then used the IPCC Special Report on Emissions Scenarios (SRES) A1B scenario to 2100 (Intergovernmental Panel on Climate Change, 2000). The models were evaluated on their ability to simulate precipitation seasonality in the western United States and also on representing a range of predicted future climates (Garfin and others, 2010). Garfin and others (2010) described the downscaling method used to rescale the GCM results to a 2.5 -minute grid $(4 \times 4 \mathrm{~km}$ grid). Of the 22 models, 3 were selected for projecting potential changes in the geographical distribution of suitable climates for ponderosa pine (Pinus ponderosa ) in the late 21st century (2070-99): (1) UKMO-HadGEM1 ( ${ }^{\circ}$ Crown copyright 2005, data provided by the Met Office Hadley Centre) (Johns and others, 2006), (2) ECHAM5/MPI-OM (Jungclaus and others, 2006), and (3) CCSM3 (Collins and others, 2006). These three models provide a range of potential future climates under the AIB emission scenario and were among the top one-half of GCMs able to represent current precipitation seasonality in the western United States (Seager and others, 2007; Garfin and others, 2010). In general, for the southwestern United States in 2070-99, the UKMO-HadGEM1 GCM forecasts a warmer climate with an enhanced summer monsoon, the ECHAM5/MPI-OM GCM forecasts a warmer and very arid climate, and the CCSM3 GCM predicts a warmer and winter-precipitation-dominant climate.

Bioclimatic models were developed using a two-stage process. First, presence data were used to run a climate limiter analysis similar to that used by Warren (1979), Arundel (2005), and Cole and others $(2008,2011)$ to identify the most important climate variables in spatially limiting the current distribution. This analysis identified candidate model variables (fig. 2.1). Probabilistic bioclimatic models were developed using presence-absence data and logistic regression with a logit link function (Hosmer and Lemeshow, 2000). Godsoe (2010) found this modeling framework robust to changes in the geography, and other modeling frameworks tended to exaggerate differences depending on the spatial configuration of the environment. Climate variables with coefficients close to 0 were dropped from the model. These methods are detailed in Ironside (2006) and Cole and others (2008, 2011). Non-linear terms such as quadratic terms often were found to contribute little to the models (coefficients close to 0 ). 
Model performance was evaluated by randomly withholding 33 percent of the presence-absence data and calculating commission of presences, Area Under the receiver operating Curve (AUC).

Probability surfaces were converted to binary results by using threshold values calculated using sensitivity-specificity equality (Liu and others, 2005). Plant migration rates were integrated into future projections for species included in the model, using a migration rate of $50 \mathrm{~m} / \mathrm{yr}$ for long-lived "climax" species, and a rate of $500 \mathrm{~m} / \mathrm{yr}$ for early successional species (van Riper and others, 2014). Migration potential was applied by buffering the current range. Projected future suitable climates for 30-year periods over the next century (2010-39, 2040-69, and 2070-99) were used to forecast areas within the present species range that would become unsuitable, remain suitable, or become newly suitable within migration distance. As time progressed in the future forecasts, we also identified areas that became unsuitable, but became suitable again in a future time-step defined as "recolonized". This is best interpreted as areas that might recruit again after a period of poor or no recruitment, as we did not specifically model mortality. Parts of the ranges designated as unsuitable are best interpreted as populations in decline, where seed production, recruitment, and (or) plant vigor is predicted to be poor. The time frame in which a plant species would become absent or disappear from the system is unknown.

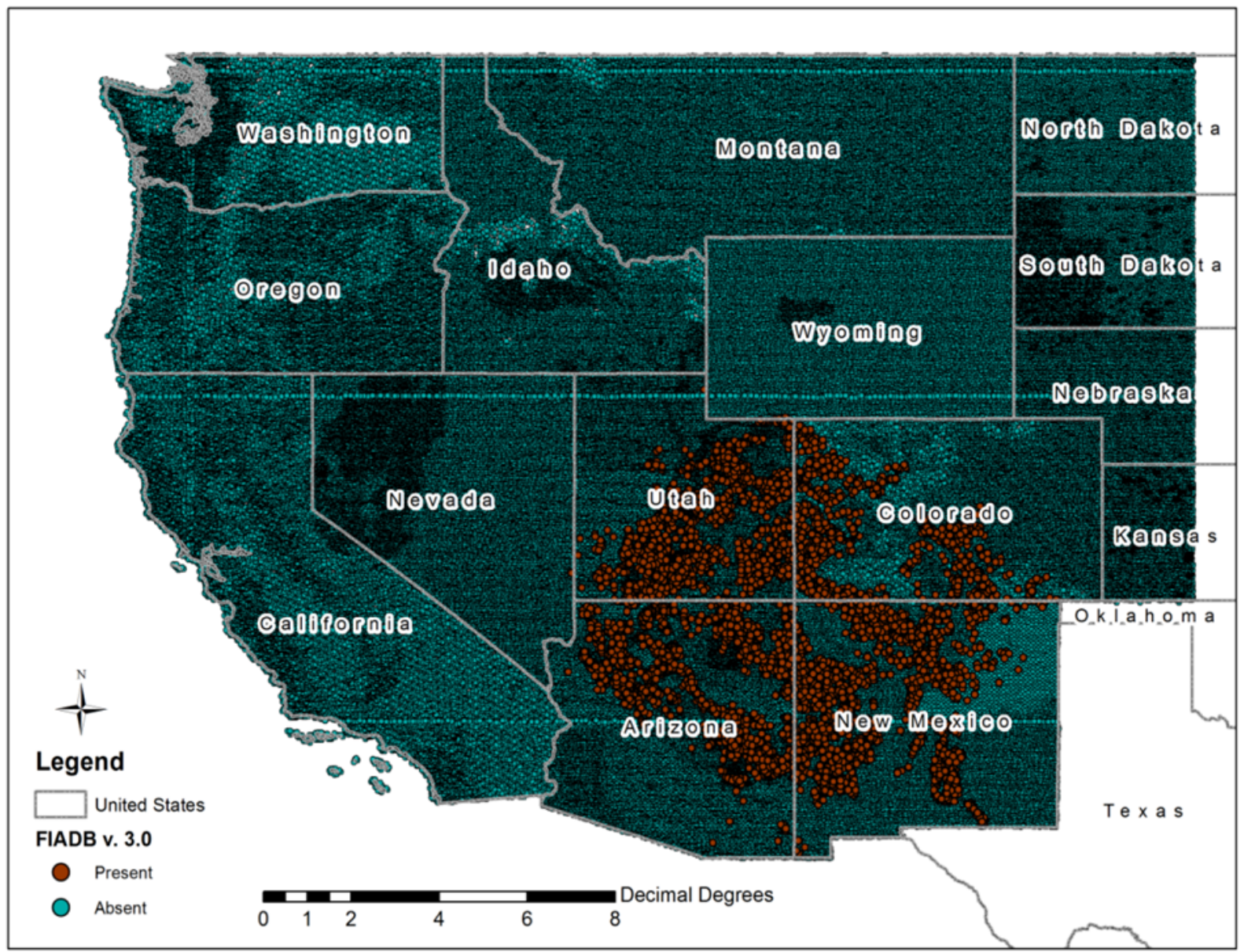

Figure 2.1. Forest Inventory and Analysis DataMart (FIADB version 3.0) database results for the presence and absence of Pinus edulis. 


\section{Results Using Pinyon Pine (Pinus edulis) as an Illustration}

\section{Distribution}

Our study area encompassed the western continental United States west of the 100th meridian. At this extent, shown in figure 2.1, the FIADB version 3.0 data available at time of download resulted in 7,826 FIA plots documenting the presence of Pinus edulis. Including FIA phase 1 plots (non-forest). 486,688 FIA plots were absent of Pinus edulis (fig. 2.1). We randomly created a subset of absence locations to avoid overwhelming the statistical models with absence locations in relation to the number of presences, but also to adequately sample the range of environmental conditions across our study area. We decided that an approximately 3-to-1 ratio of absences to presences would provide adequate coverage of the study area, as Pinus edulis covers roughly one-third of the total data coverage extent. This results in roughly equal sampling intensity across the study area. We converted the presence and absence locations to a $4 \times 4 \mathrm{~km}$ grid using the climate layers as a mask and setting a grid cell with both a presence and absence location to being a presence location. Conversion to a raster layer results in a climate grid cell only being sampled once, and this process resulted in our final occurrence dataset. For pinyon pine, this process resulted in 5,182 presences and 18,827 absences, totaling $n=24,009$ observations on which the distribution was interpolated and modeled (fig. 2.2).

\section{Suitable Climate Modeling of Pinus edulis}

The climate limiter analysis calculates the range of temperature and precipitation values that a species occupies and finds the geographical distribution of that climatic envelope (the gray area in fig. 2.3) on the landscape. The analysis then excludes one variable at a time, holding the remaining variables constant, to see how the range or envelope may expand in geographical space without that variable. Variables that result in a large area of expansion are assumed to be important in limiting the distribution of the species. This exercise for Pinus edulis resulted in seven mean monthly total precipitation variables, four maximum mean monthly temperature variables, and five minimum mean monthly temperature variables as being limiting (fig. 2.3).

Upon attributing and sampling the 16 candidate variables for the presence and absence locations, the data were imported into Minitab ${ }^{\mathbb{B}}$ Statistical Software. Binary logistic regressions using the logit link were run using the presence of a species as the event, coded as 1 , and absence, coded as 0 . Results were examined for covariates showing little predictive power (coefficients close to 0), those with high standard errors, and potential switching of sign. Problems with multicollinearity can lead to large standard error estimates and reversing the sign of coefficients (Hosmer and Lemeshow, 2000). Because many of these climate variables are highly correlated with one another, we referred to the climate limiter analysis to determine if the areas indicated to be limited by that variable were colder or warmer, and wetter or drier than where Pinus edulis occurs (gray potential envelope). For example, August mean total precipitation was identified as limiting Pinus edulis from occurring in areas of the Great Basin Provenance to the northwest of its current range. This area receives less August precipitation than where Pinus edulis currently grows, suggesting that Pinus edulis occurrence is positively associated with August precipitation (as August precipitation increases, so does the likelihood than Pinus edulis will occur). The model for Pinus edulis is presented in table 2.1, which shows that the relation between August mean total precipitation and the event that Pinus edulis is present is correctly specified as positive. The Pinus edulis model resulted in all 16 candidate variables providing some explanatory power, and our large sample size allows for large numbers of parameters, reducing the risk of overfitting. In the case of Pinus edulis, all 16 variables were retained, as standard errors were not large and no evidence for reversal of the sign of a relation was found. The model results were used to develop 
an equation for use in ArcGIS ${ }^{\circledR}$ raster calculator using mathematical algebra. A probability surface was generated showing the probability of Pinus edulis occurrence given the 16 climate parameters (fig. 2.4). We identified an optimal probability threshold balancing commission and omission error by identifying sensitivity-specificity equality (fig. 2.5; Liu and others, 2005). Projected future binary suitable climate for 30-year periods over the next century (2010-39, 2040-69, and 2070-99) and migration estimates were used to identify how changes in climate may affect the range of Pinus edulis (for example, see fig. 2.6).
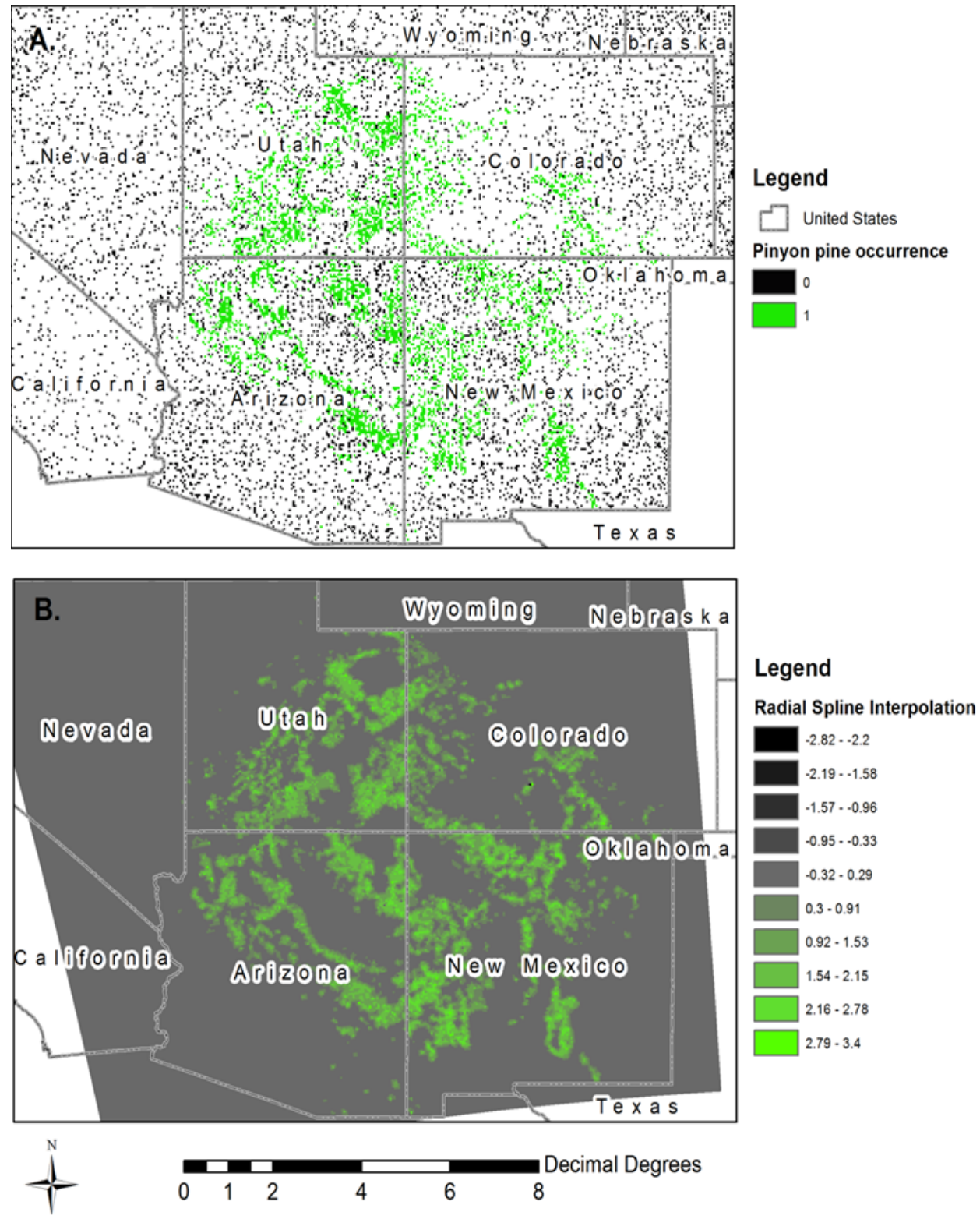

Figure 2.2. (A) Processed occurrence data where absence locations were randomly subsampled and data were converted to raster format. (B) Radial based spline interpolation of occurrence data to generate a current distribution map of Pinus edulis using a $=>0.10$ threshold. 


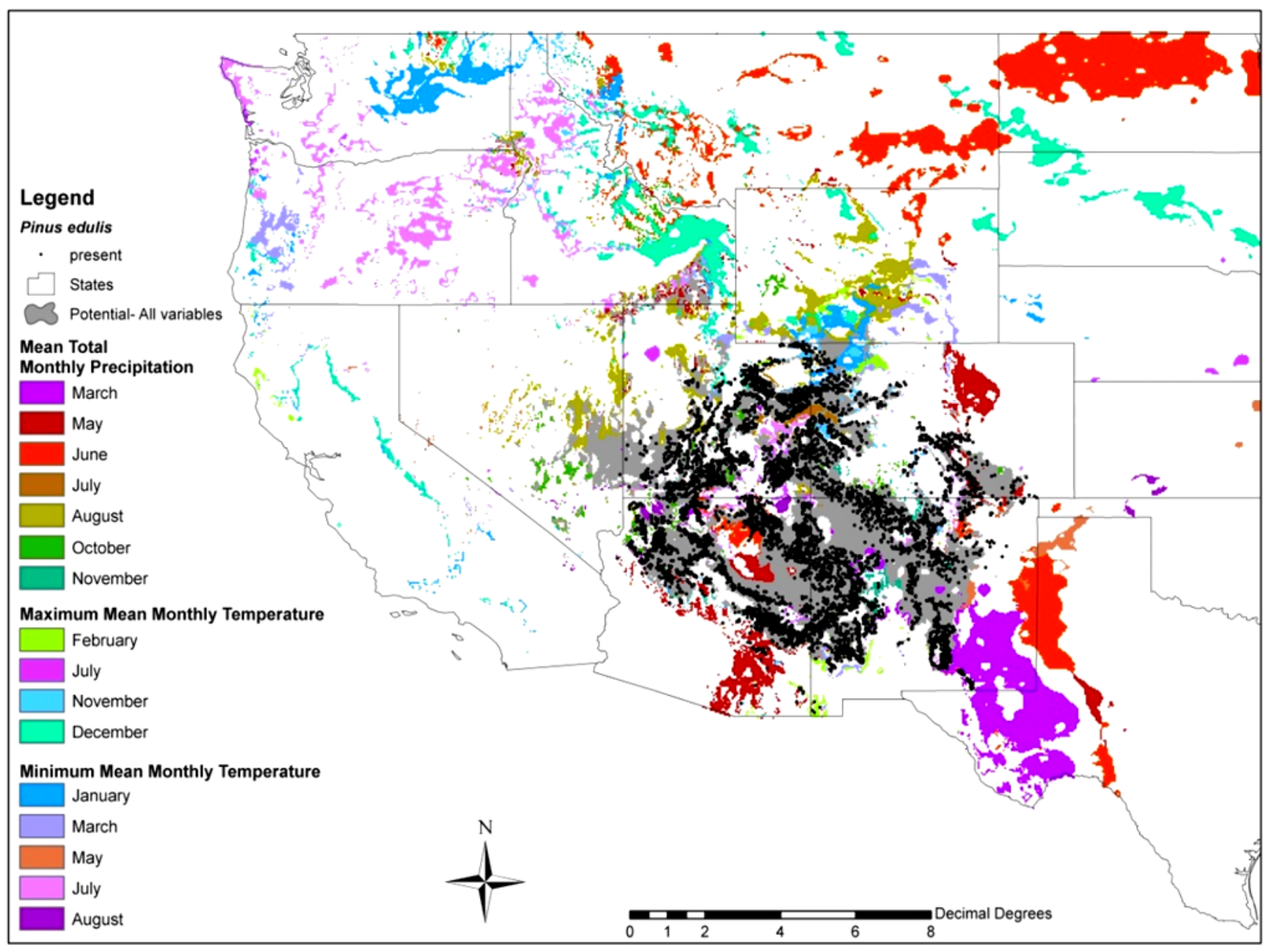

Figure 2.3. Climate limiter analysis results for Pinus edulis. Sixteen variables were identified as potentially important in limiting the distribution from occurring on various locations on the landscape. Areas shown in white are where more than one variable limits occurrence. 


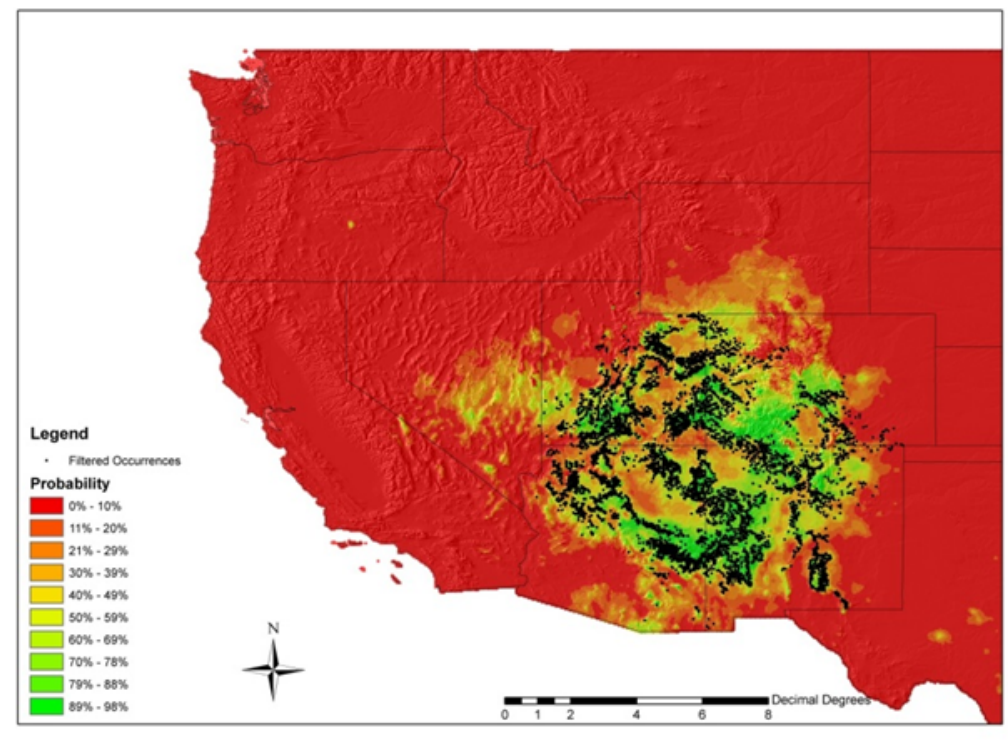

Figure 2.4. Probability of Pinus edulis occurrence given the climate of 1950-99.

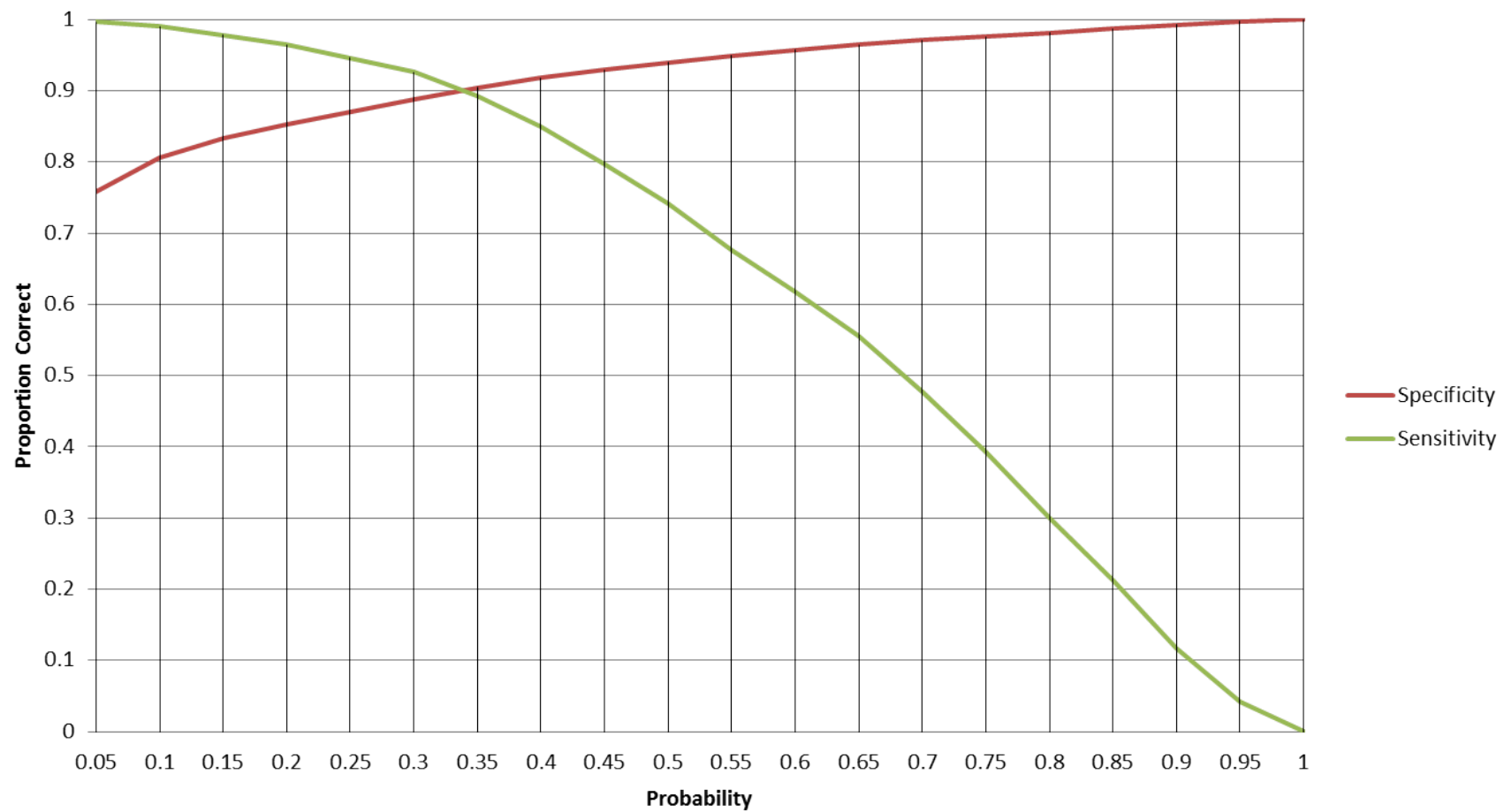

Figure 2.5. A probability threshold was calculated to produce binary model results that optimizes classification accuracy for both presence and absence occurrence records. For Pinus edulis 0.34 was the optimal threshold where $\sim 90$ percent of both presence records (sensitivity) and absence records (specificity) were classified correctly. 


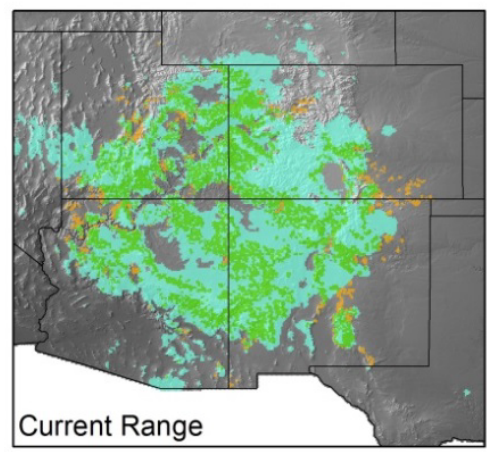

\section{Pinus edulis, Pinyon Pine, Projected Changes in Species Range: CCSM3 SRES A1B}

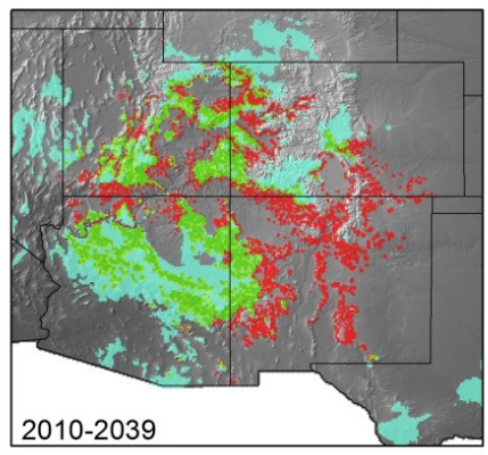

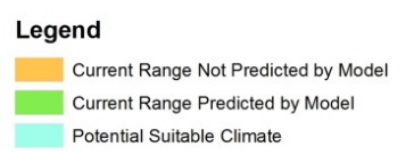

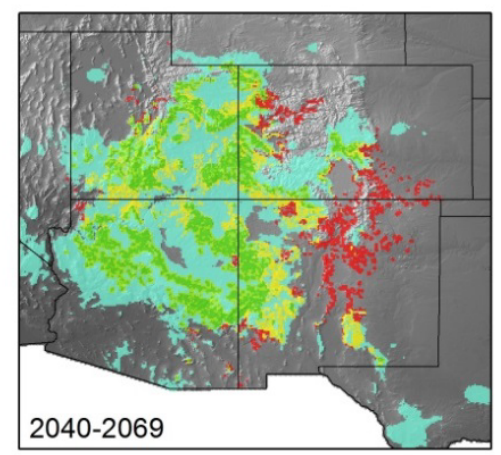

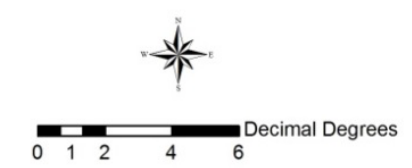

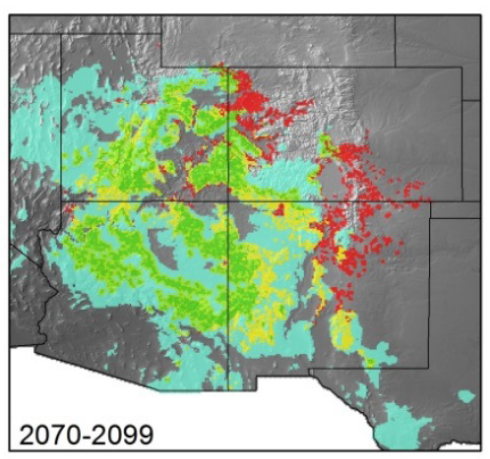

Figure 2.6. Projected changes in suitable climate and range of pinyon pine (Pinus edulis) for the CCSM3 SERS A1B climate change scenario. Multiple model projections identify areas where pinyon pine currently exist that were not identified as suitable, current range that was correctly predicted by the model, and potentially suitable climate zones that currently are unoccupied by pinyon pines. Projected across three climate intervals, locations are identified by the model as unsuitable or suitable for pinyon pine, and locations where they could potentially migrate or recolonize. Lastly, areas are identified by the model where pinyon pine may not be able to migrate in the three timeframes identified without some form of human assistance. 
Table 2.1. Logistic binary regression model predicting the suitable climate of pinyon pine (Pinus edulis).

[This model was developed on PRISM climate data for the period 1950-99 using the native cell integer values of degrees Celsius $\times 100$ and millimeters precipitation $\times 100$ ]

\begin{tabular}{|c|c|c|c|c|c|}
\hline Variable & Coefficient & Standard error & Chi-square & P-value & Odds ratio \\
\hline Intercept & -3.7690000 & 0.5350000 & 13514.4 & 0.0000 & NA \\
\hline $\begin{array}{l}\text { January minimum mean monthly } \\
\text { temperature [mntme } 01]\end{array}$ & 0.0004830 & 0.0001900 & 6.54 & 0.0110 & 1.0005 \\
\hline $\begin{array}{l}\text { March minimum mean monthly } \\
\text { temperature [mntme } 03]\end{array}$ & -0.0012920 & 0.0003250 & 15.89 & 0.0000 & 0.9987 \\
\hline $\begin{array}{l}\text { May minimum mean monthly } \\
\text { temperature [mntme05] }\end{array}$ & -0.0045150 & 0.0003610 & 161.14 & 0.0000 & 0.9955 \\
\hline $\begin{array}{l}\text { July minimum mean monthly } \\
\text { temperature [mntme } 07]\end{array}$ & 0.0035360 & 0.0004050 & 79.16 & 0.0000 & 1.0035 \\
\hline $\begin{array}{l}\text { August minimum mean monthly } \\
\text { temperature [mntme } 08]\end{array}$ & -0.0011450 & 0.0004440 & 6.66 & 0.0100 & 0.9989 \\
\hline $\begin{array}{l}\text { February maximum mean monthly } \\
\text { temperature }[\mathrm{mxtme} 02]\end{array}$ & -0.0019250 & 0.0003520 & 29.95 & 0.0000 & 0.9981 \\
\hline $\begin{array}{l}\text { July maximum mean monthly } \\
\text { temperature [mxtme07] }\end{array}$ & 0.0015900 & 0.0003870 & 16.86 & 0.0000 & 1.0016 \\
\hline $\begin{array}{l}\text { November maximum mean monthly } \\
\text { temperature [mxtme11] }\end{array}$ & -0.0041320 & 0.0003140 & 177.04 & 0.0000 & 0.9959 \\
\hline $\begin{array}{l}\text { December maximum mean monthly } \\
\text { temperature [mxtme12] }\end{array}$ & 0.0050790 & 0.0003410 & 231.98 & 0.0000 & 1.0051 \\
\hline $\begin{array}{l}\text { March mean monthly total precipitation } \\
\text { [pptme } 03]\end{array}$ & -0.0002420 & 0.0000520 & 21.41 & 0.0000 & 0.9998 \\
\hline $\begin{array}{l}\text { May mean monthly total precipitation } \\
\text { [pptme } 05]\end{array}$ & 0.0003110 & 0.0000500 & 38.9 & 0.0000 & 1.0003 \\
\hline $\begin{array}{l}\text { June mean monthly total precipitation } \\
\text { [pptme } 05]\end{array}$ & -0.0011650 & 0.0000600 & 401.56 & 0.0000 & 0.9988 \\
\hline $\begin{array}{l}\text { July mean monthly total precipitation } \\
\text { [pptme } 07]\end{array}$ & -0.0007330 & 0.0000420 & 316.31 & 0.0000 & 0.9993 \\
\hline $\begin{array}{l}\text { August mean monthly total precipitation } \\
\text { [pptme } 08]\end{array}$ & 0.0011590 & 0.0000430 & 802.47 & 0.0000 & 1.0012 \\
\hline $\begin{array}{l}\text { October mean monthly total } \\
\text { precipitation [pptme10] }\end{array}$ & 0.0015530 & 0.0000580 & 811.85 & 0.0000 & 1.0016 \\
\hline $\begin{array}{l}\text { November mean monthly total } \\
\text { precipitation [pptme11] }\end{array}$ & -0.0011580 & 0.0000820 & 264.44 & 0.0000 & 0.9988 \\
\hline
\end{tabular}

Log-Likelihood $=-5765.575$

Test that all slopes are $0: \mathrm{G}^{*}=13514.397$, degrees of freedom $(\mathrm{DF})=16, \mathrm{P}-$ Value $=0.000$

${ }^{*} \mathrm{G}$ statistic is the log-likelihood ratio test, a chi-square test, where the null hypothesis that all the coefficients associated with predictors (i.e. the slopes) equal zero versus these coefficients not all being equal to zero. This is used as a measure of the regression model's significance.

Area Under the receiver operating Curve (AUC) $=94.6$ of randomly withheld test data

Raster Calculator Equation -

prediction $=1 \operatorname{div}(1+(\exp (-(-3.76918+(0.0004825 *[\mathrm{mntme} 01])+(-0.0012924 *[\mathrm{mntme} 03])+(-0.0045153 *$ $[\mathrm{mntme} 05])+(0.0035360 *[\mathrm{mntme} 07])+(-0.0011447 *[\mathrm{mntme} 08])+(-0.0019253 *[\mathrm{mxtme} 02])+(0.0015897 *$ $[\mathrm{mxtme} 07])+(-0.0041321 *[\mathrm{mxtme} 11])+(0.0050791 *[\mathrm{mxtme} 12])+(-0.0002424 *[\mathrm{pptme} 03])+(0.0003114 *$ $[$ pptme 05$])+(-0.0011653 *[$ pptme 06$])+(-0.0007334 *[$ pptme07] $)+(0.0011586 *[$ pptme08] $)+(0.0015530 *[p p t m e 10])$ $+(-0.0011584 *[$ pptme11])) $)))$ 


\section{Appendix 3. Modeling Bird and Reptile Distributions (Modified from Van Riper and others, 2014, with Permission)}

\section{Overview}

Choice of background data can have important effects on projections (VanDerWal and others, 2009), so we used a random background set of data from the entire set of possible locations throughout the western United States to serve as absence (birds) or pseudo-absences (reptiles). A large number of locations from a broad range of conditions were used to ensure representation of all possible environments, which is important when models are projected into future climates (Elith and others, 2010). We only considered variables derived from our conceptual diagrams for model development and verification, instead of using large datasets tied to automated forward or backward stepping routines and Akaike's Information Criterion (AIC) selection, because the latter approach can lead to overfit models (Anderson and Burnham, 2002; Arnold, 2010). We screened the selected variables for collinearity, evaluated covariate significance with backward stepping and $\chi 2$ statistic, and checked for linearity between logit and continuous variables with quadratic and cubic terms (Hosmer and Lemeshow, 1989).

\section{Bird Distribution Models}

\section{Statistical Design}

We developed an environmental dataset for spatial modeling bird distributions by using a casecontrol sampling design (Keating and Cherry, 2004). Specifically, we compared a set of randomly selected presence locations with a set of absence locations, using 80 percent of presence-absence locations for model construction and 20 percent for model testing. Absence data were selected randomly from areas that had been searched between 1990 and 2009 and found to not contain a given bird species. Whenever a cell contained both presence and absence data, given that one year may contain the focal species and the next year not, we prioritized presence over absence. Thus, any cell between 1990 and 2009 that contained a presence record of a focal species was assigned a presence rating. Presenceabsence observations were assigned to the center of the cell (centroid); thus, all detections were at least $4 \mathrm{~km}$ apart from one another. For robust estimation of each parameter, we ensured that there were at least 10 presence observations per parameter in every candidate model (Peduzzi and others, 1996). 


\section{Spatially Explicit Modeling}

We used binary logistic regression, considering both univariate and multivariate models, to identify environmental associations and to develop equations useful for spatially explicit (geographical information system [GIS]-based) distribution models. Logistic regression is ideal for evaluating relations between predictor variables and a species range because presence-absence data are binary (Keating and Cherry, 2004). We used Arc/Info ${ }^{\circledR}$ GRID (Environmental Systems Research Institute, $1992)$ to calculate and map the probability that a species would be present within $16-\mathrm{km}^{2}(4 \times 4 \mathrm{~km})$ cells. We calculated the relative probability $(P)$ with the following equation:

$$
P=e^{g(x)} / 1+e^{g(x)}
$$

where $g(x) \quad$ is the linear combination of parameter estimates obtained from the logistic regression (Hosmer and Lemeshow, 1989).

In equation 1, the relative suitability of an area is linked to the probability of breeding season occupancy based on the logistic regression under consideration. Each model assigned cells a probability between 0 and 99 percent. The expression $e$ is an exponential function, approximately equal to 2.718281828 .

\section{Multivariate Model Selection and Fit}

We only considered variables derived from our conceptual models for model development and verification, as opposed to using large datasets tied to automated forward or backward stepping routines and AIC selection. We screened variables for collinearity by examining pairwise Pearson's correlation coefficients among all pairs of variables and then evaluated the significance of each covariate in our models with the G-statistic, which is analogous to the $\chi^{2}$ statistic, produced from backwards stepping and a log-likelihood ratio test (Hosmer and Lemeshow, 1989). We checked for linearity between the logit and continuous variables through the incorporation of quadratic and cubic higher-order terms. Given the importance of habitat suitability in our analyses, we relied on receiver operating characteristic (ROC) area under the curve (AUC; Egan, 1975) and a classification table (Story and Congalton, 1986) to determine the performance of each candidate model. We did not rely solely on AIC (Burnham and Anderson, 2002) in our selection process because it consistently supported very large and cumbersome models that were difficult to interpret and performed little or no better than simpler models. For the sake of brevity, we only present models that achieved the highest classification accuracies and were ecologically interpretable. We evaluated the relative contribution of variables included in each logistic regression model by the Wald $\chi^{2}$ statistic, which is proportional to the contribution of a variable to explaining variation in the response, and is conditional on the model. 
Model Verification

Spatial accuracies of our logistic-regression models were assessed with an independent dataset (that is, withheld bird species presence locations not used in model development). Model accuracies depended on a movable probability cutpoint used to delineate (extract) suitable versus unsuitable breeding locations (cells) from the probability grid. For our analyses, we selected probability cutpoints (thresholds) that roughly balanced commission and omission errors. Model accuracies were calculated as model sensitivity ( 1 - omission error), specificity ( 1 - commission), and overall accuracy (sensitivity + specificity $\div 2$ ). Presence locations that were outside a projected distribution were counted as an omission error (Story and Congalton, 1986), whereas cells that were predicted to be occupied but found to be empty were counted as a commission error.

\section{Reptile Distribution Models}

\section{Statistical Design and Spatially Explicit Modeling}

All reptile models were fitted in maximum entropy modeling (Maxent) by taking advantage of built-in functions for random seeds, background selection, cross-validation, and model averaging (Phillips and Dudík, 2008). Although choice of background data can have important effects on projections (VanDerWal and others, 2009), we used a random background set of data from the entire set of possible locations throughout the western United States to serve as pseudo-absences. A large number of locations $(10,000)$ from a broad range of conditions was used to ensure good representation of all possible environments, which is important when models are to be projected into very different conditions, as would be the case with future climates (Elith and others, 2010). We avoided bias of background samples by weighing samples according to variations in cell area because all covariate data for this study were unprojected. We then fitted models using five-fold cross-validation to estimate errors around fitted functions and to determine predictive performance using withheld data (Elith and others, 2010). In practice, this meant that the algorithm randomly selected and withheld 20 percent of the cells containing presences for use in model testing for each "fold." The remaining 80 percent of reptile species presences were used for model training.

\section{Multivariable Model Selection}

All variables that we identified as important in the conceptual models for each reptile taxon were initially included in a model, although we did not include any variables that would account for spatial patterns in the distributional data. For the most part we used default settings in Maxent for model development, but restricted variable specification to hinged, quadratic, and categorical features (in machine learning language, features are transformations of variables into functions). These features produce model projections similar to those based on generalized linear or additive models (Phillips and Dudík, 2008; Elith and others, 2010), which made the models produced by Maxent comparable to those developed for birds using logistic regression. We did not select automatic examination of interacting variables because of the complexity of interpreting ad hoc interactions, nor did we select linear or threshold features because these tend to be redundant with hinge features (Elith and others, 2010). Default regularization parameters were selected for all models because we did not have data on the relative or absolute detectability of the different reptile species. 
We examined correlations among all continuous variables by calculating the Pearson pairwise correlation coefficients using "ENM Tools" (Ecological Niche Modeling Tools software by Warren and others, 2010). However, we did not exclude correlated variables because the strength of correlations varied spatially and because analyses also have shown that Maxent is more stable to the effects of correlated variables compared to stepwise regression (Hastie and others, 2009). To choose whether models should include the effects of plant species distributions, we first calculated raw outputs from Maxent models to select the most parsimonious model based on $\mathrm{AIC}, \mathrm{AIC}_{\mathrm{c}}$, and Bayesian Information Criterion (BIC) (Burnham and Anderson, 2002; Warren and Seifert, 2011). Then, using the most parsimonious model, we calculated both models that included and excluded the effect of distribution of different plant species.

\section{Model Accuracy of Bird and Reptile SDMs}

We assessed classification accuracy of each candidate species distribution model (SDM; logistic regression or maximum entropy) with receiver-operating-characteristic (ROC) curves and classification tables (Egan, 1975; Story and Congalton, 1986). We did not rely on AIC (Burnham and Anderson, 2002) in our model selection process because it often supports overfit models that have poor generality (Guthery and others, 2005). In an exploratory analysis, we found AIC to be consistently supported very large models (for example, $>20$ estimable parameters) that were difficult to interpret and performed only slightly better, or no better, than simpler models (for example, $<10$ parameters).

We assessed the spatial accuracies of our SDMs with randomly selected presence and absence locations that were withheld from model development. Model accuracies depended on a movable probability cutpoint (threshold) to delineate suitable versus unsuitable locations (4-km cells) from each probability grid. We selected probability thresholds that balanced commission and omission errors (van Riper and others, 2014). Model accuracies were calculated as model sensitivity (1 - omission error), specificity (1 - commission), and overall accuracy (sensitivity + specificity $\div 2$ ). Presence locations that were outside a projected distribution were counted as an omission error, whereas cells that were predicted to be occupied but found to be empty were counted as a commission error (Story and Congalton, 1986). 


\section{Appendix 4. Bird Species Modeling Example 1}

\section{Life-History of Juniper Titmouse (Baeolophus ridgwayi)}

As its name suggests, the juniper titmouse inhabits juniper and pinyon-juniper woodlands of the intermountain region (Cicero, 2000). Locally distributed throughout its range, it is a resident species, and pairs defend their territories year-round. They are most common where juniper is dominant and where large, mature trees occur and provide natural cavities for nesting and roosting. They also use woodpecker-excavated cavities. Their food consists of seeds and terrestrial invertebrates, with plant material comprising most of their diet in fall and winter. Metabolism and temperature regulation are important in determining the northern range limit of the species. The availability of cavities for nesting and roosting may regulate populations. Juniper titmouse was included in the 2014 State of the Birds report (North American Bird Conservation Initiative, 2014) in their western forests indicator, comprised of 39 western forests obligate species. The western forest indicator has declined nearly 20 percent, and within the group, juniper titmouse shows a non-significantly decreasing population trend of -0.44 , from 1968 to 2012.

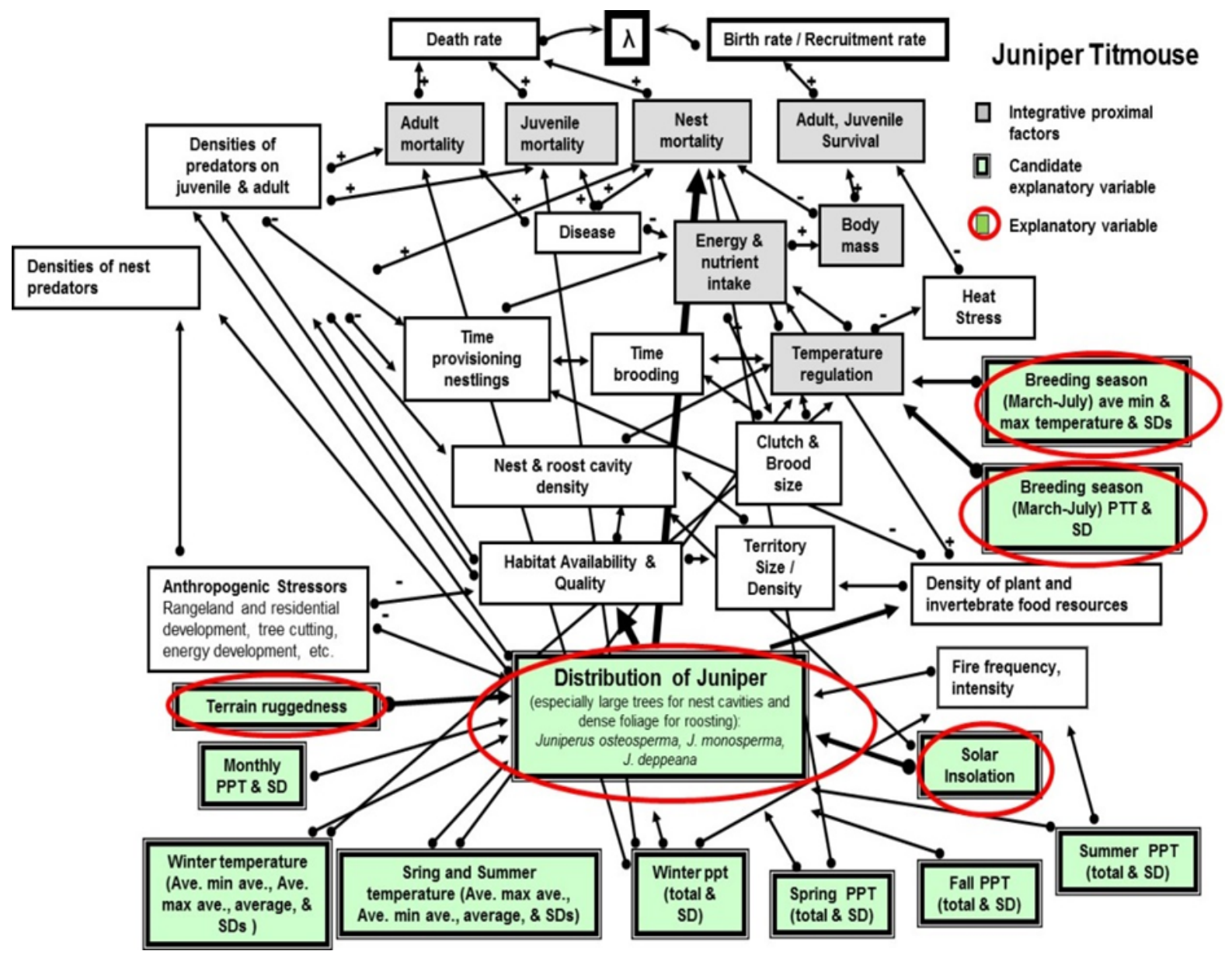

Figure 4.1. Conceptual model of Juniper Titmouse range and population dynamics, including explanatory variables used to model current (i.e., 2009) range (in green and circled red). The relative strength of different effects is denoted by the width of connecting arrows. 


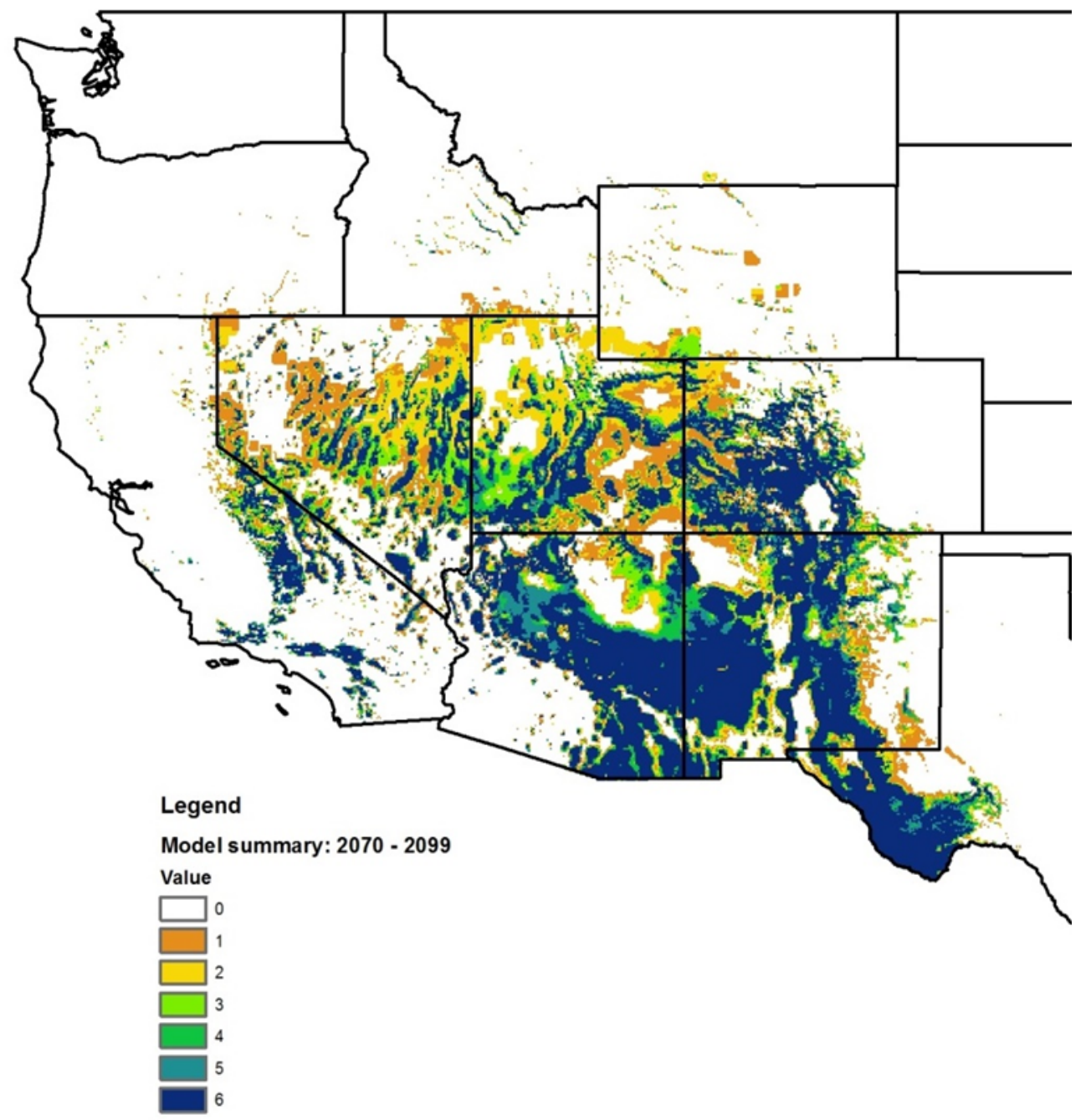

Figure 4.2. Predicted Juniper Titmouse range in 2099, showing levels of agreement among predictions based on 5 different statistically downscaled GCMs plus a 6th representing an ensemble of $22 \mathrm{GCMs}$. White denotes areas where all projections agree there will not be Juniper Titmouse range, whereas blue denotes areas where all agree there will be range. 


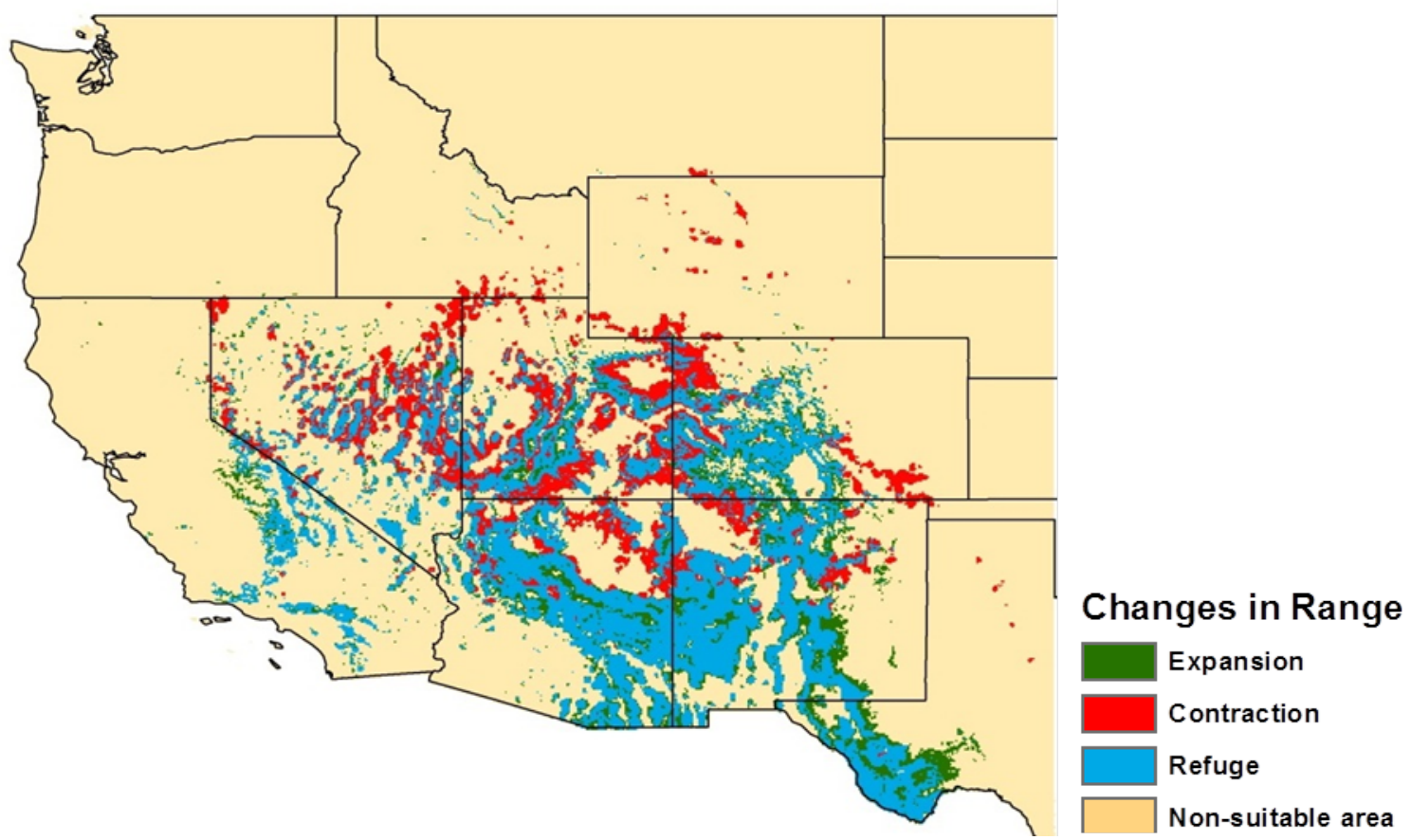

Figure 4.3. Areas where $\geq 5 \mathrm{GCM}$ projections predict there will be Juniper Titmouse range in 2099 compared to range in 2009, showing areas of range contraction (red), range expansion (green), and range persistence (refuge blue) between 2000 and 2099.

Model accuracy 74 percent

Area Under the receiver operating Curve (AUC) with plant species ranges 0.81

AUC without plant species ranges 0.75

Rank order of variable influence in model, Relationship, Sign:

1. Utah juniper (Juniperus osteosperma) range (JUOS), Monotonic, +

2. Oneseed juniper (Juniperus monosperma) range, (JUMO), Monotonic, +

3. Insolation (May), Monotonic, +

4. Mean Breeding Season (March-July) precipitation (PPTAVG_37), Quadratic, +/-

5. Terrain ruggedness, Quadratic, +/-

6. Mean Breeding Season (March-July) temperatures (TMPAVG_37), Monotonic, + 


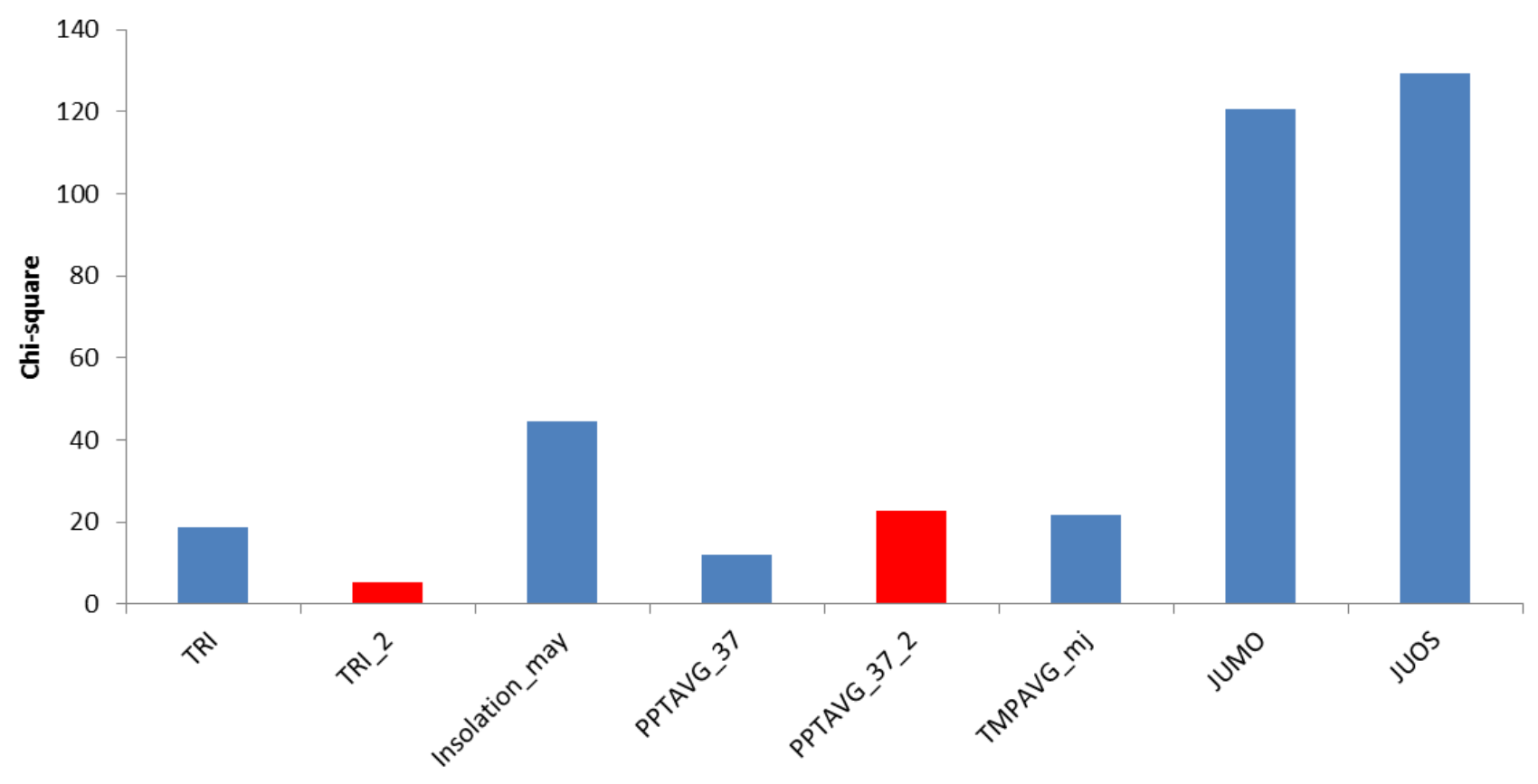

Predictor variable

Figure 4.4. Relative influence of variables retained in the Juniper Titmouse best model of contemporary range, as measured by the chi- squared statistic. Blue denotes a positive effect; red denotes a negative effect. Variables with a "2" denote a quadratic term. 

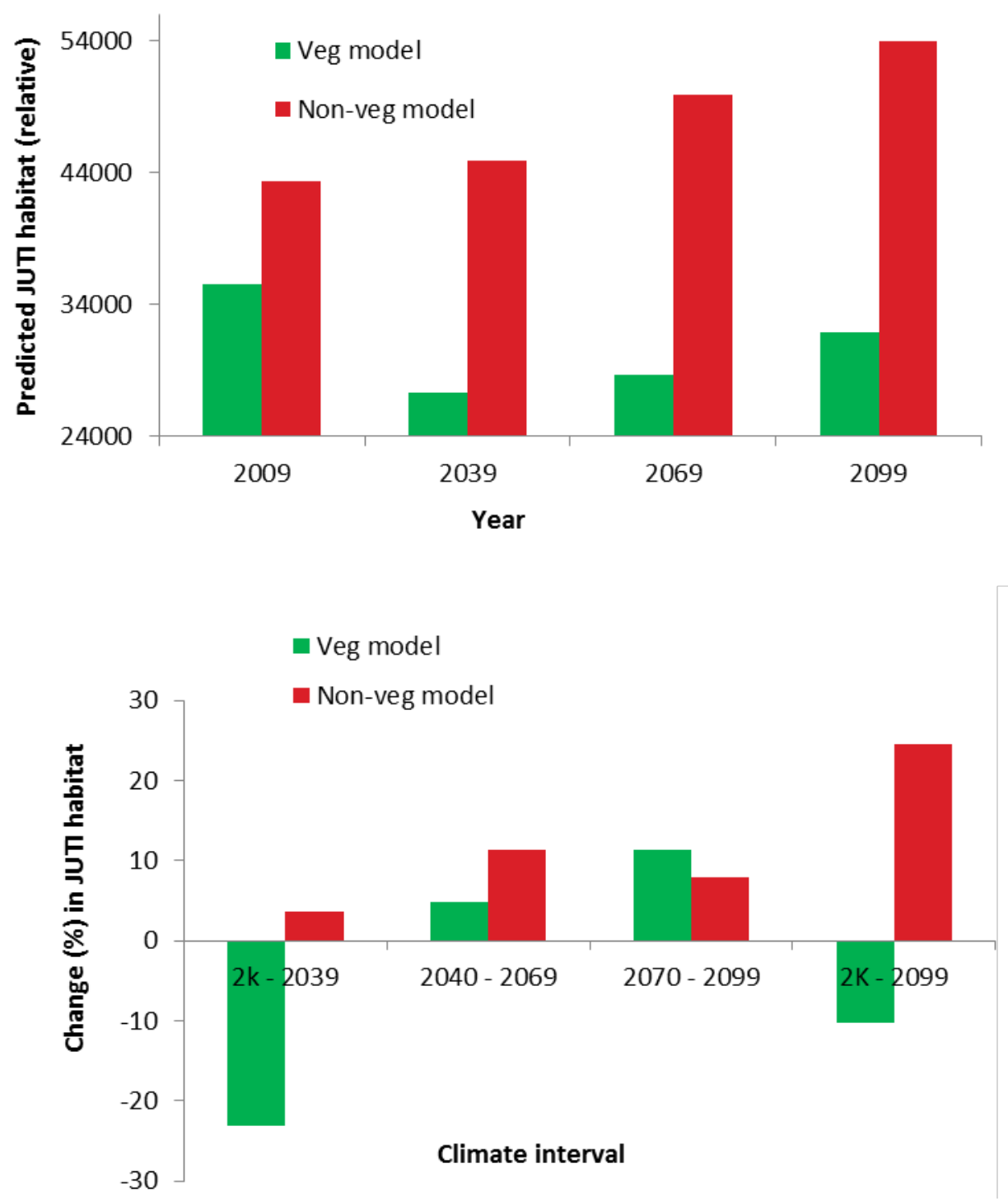

Figure 4.5. Measures of range change among four time intervals during 2009-2099. Top figure shows extent of modeled current (i.e., 2009) or projected future range in terms of area. Bottom figure shows change in range extent as a percentage of contemporary range. Green bars are results produced by model that include effect of plant species ranges; red bars are results produced by the model that do not include plant range effects. Values were calculated based on areas of agreement of at least five of the six climate projections. 


\section{Appendix 5. Reptile Species Modeling Example 1}

\section{Life-History of Sagebrush Lizard (Sceloporus graciosus)}

The sagebrush lizard has a very broad distribution in the Western United States, extending from Washington, Idaho and Montana to northern Arizona and New Mexico and southern California, including parts of Baja California, Mexico (Hammerson, 2007). It is associated with many vegetation types, primarily shrublands such as those dominated by sagebrush, but also open areas that include pinyon-juniper, ponderosa pine, and Douglas-fir forests (Jones and Lovich, 2009). It is a primarily ground-dwelling species and its food consists of a variety of arthropods, including ants, flies, spiders, and beetles. Sagebrush lizard relies on open habitats, especially at high altitudes, for thermoregulation, and it commonly is found when temperatures are between 22 and $37^{\circ} \mathrm{C}$. Important variables that influence the limits of its distribution include the amount of summer and winter rains, maximum summer temperatures, and amount of solar radiation.

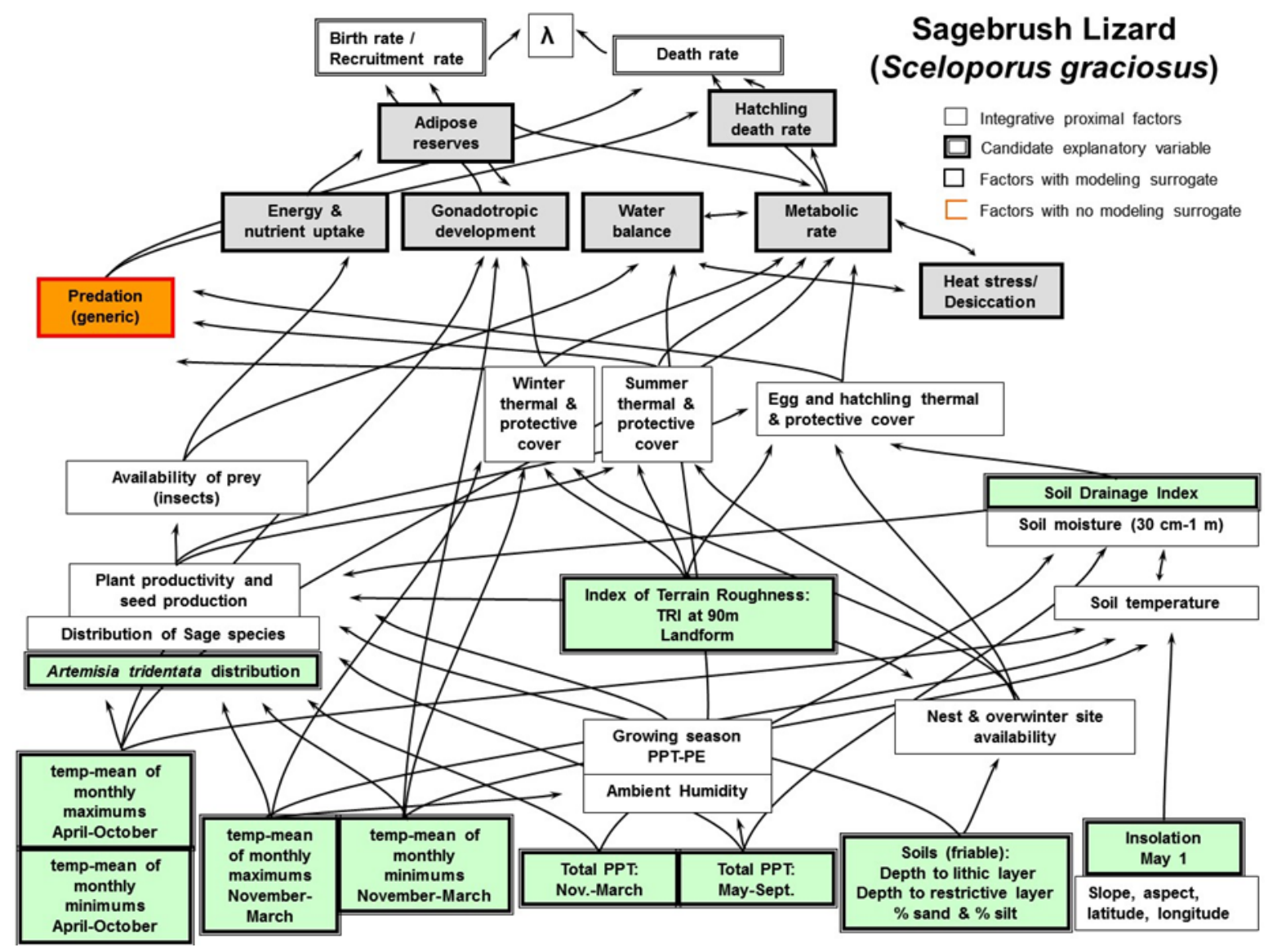

Figure 5.1. Conceptual model of factors that influence the distribution and population dynamics of the Sagebrush lizard, including explanatory variables used to model current range (in green). 


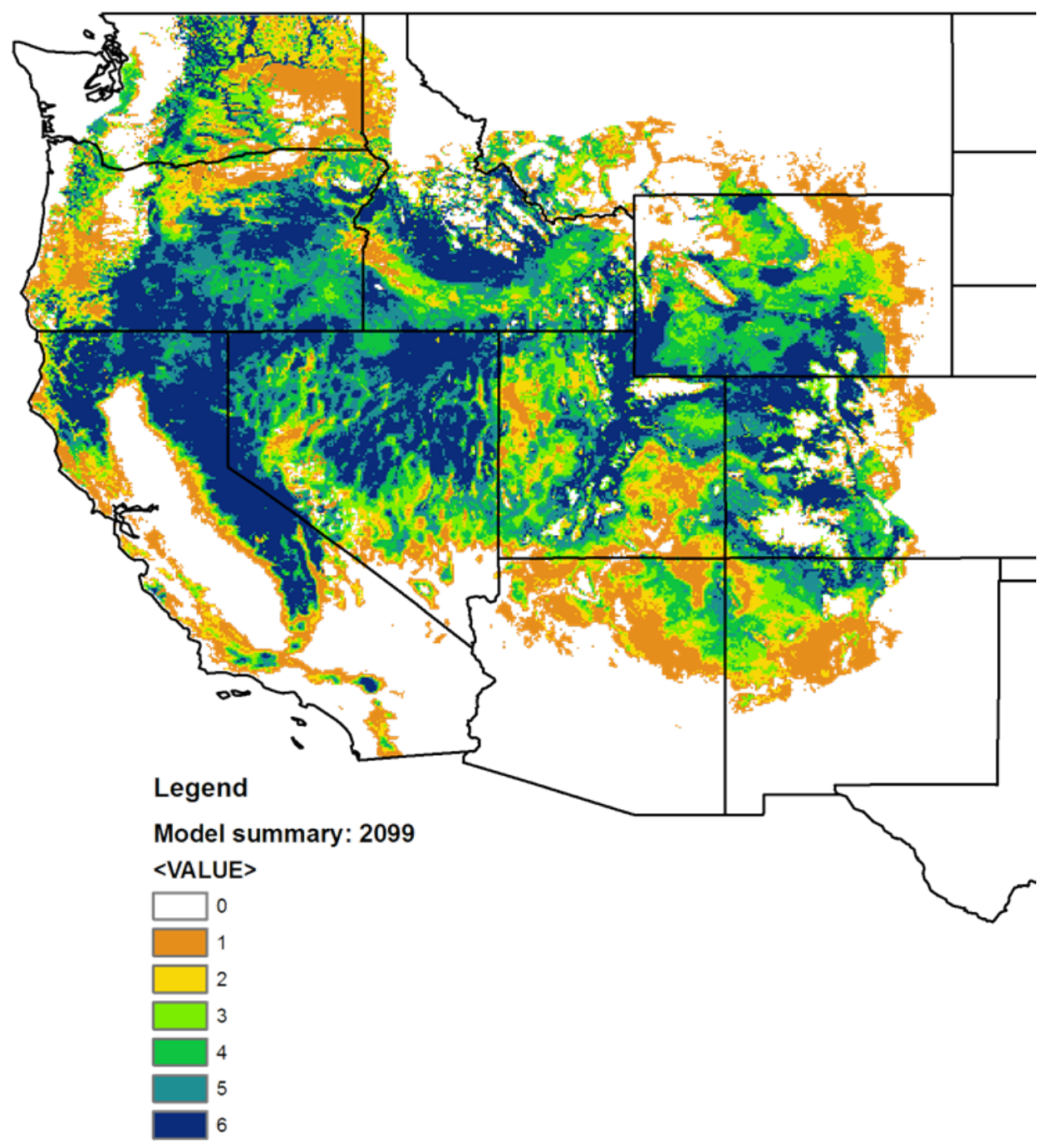

Figure 5.2. Predicted Sagebrush lizard range in 2099, showing levels of agreement among predictions based on 5 different statistically downscaled GCMs plus a 6th representing an ensemble of 22 GCMs. White denotes areas where all projections agree there will not be Sagebrush lizard range, whereas blue denotes areas where all agree there will be range. Map based on model that excludes vegetation. 


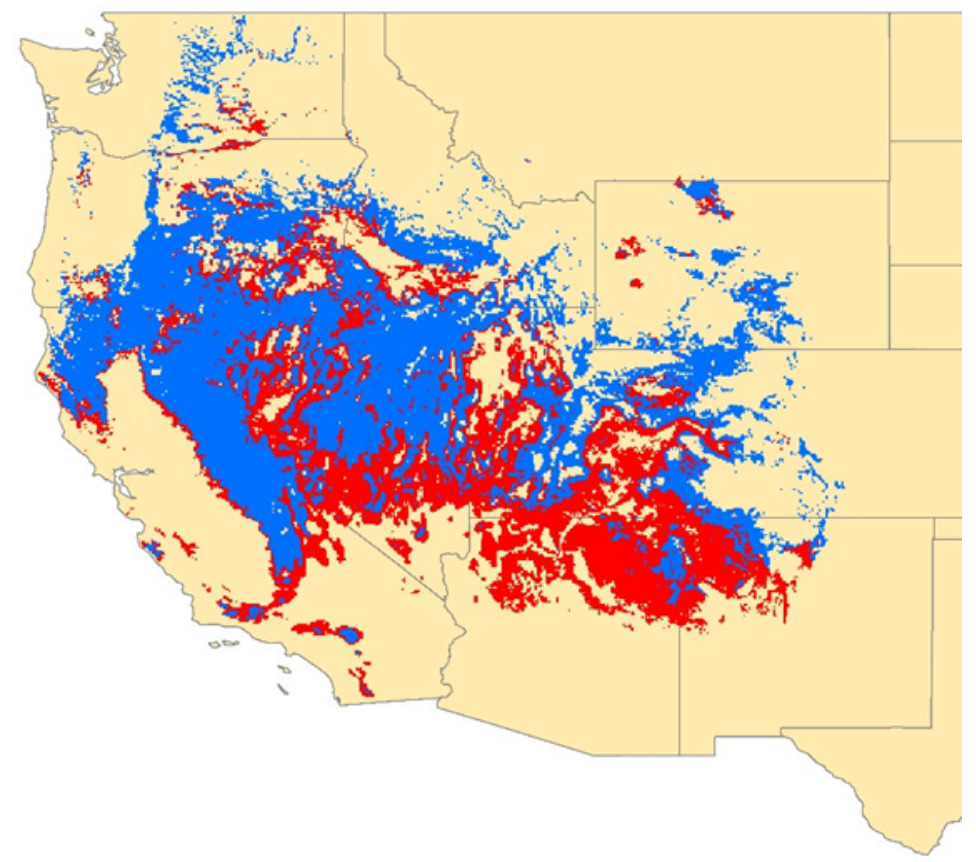

Figure 5.3. Areas where $\geq 5 \mathrm{GCM}$ projections predict range of the Sagebrush lizard in 2099 compared to range in 2009, showing areas of range contraction (red) and range persistence (refuge - blue) between 2009 and 2099.

Area Under the receiver operating Curve (AUC) with plant species ranges 0.87 AUC without plant species ranges 0.87

Rank order of variable influence in model:

1. Precipitation (sum May-September)

2. Maximum Temperatures (mean April-September)

3. Insolation (May)

4. Precipitation (sum November-March) 


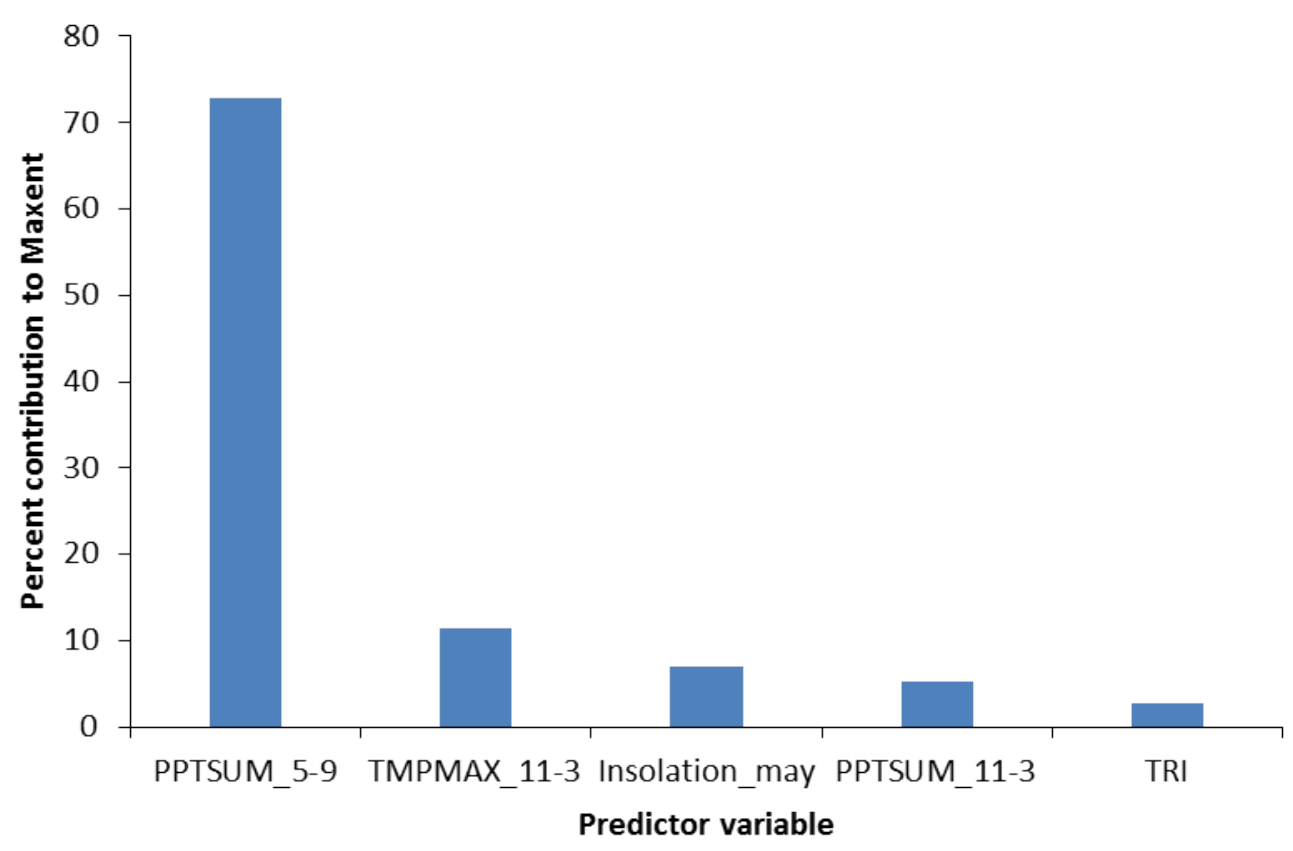

Figure 5.4. Relative influence of variables retained in the best model of contemporary range for Sagebrush lizard.

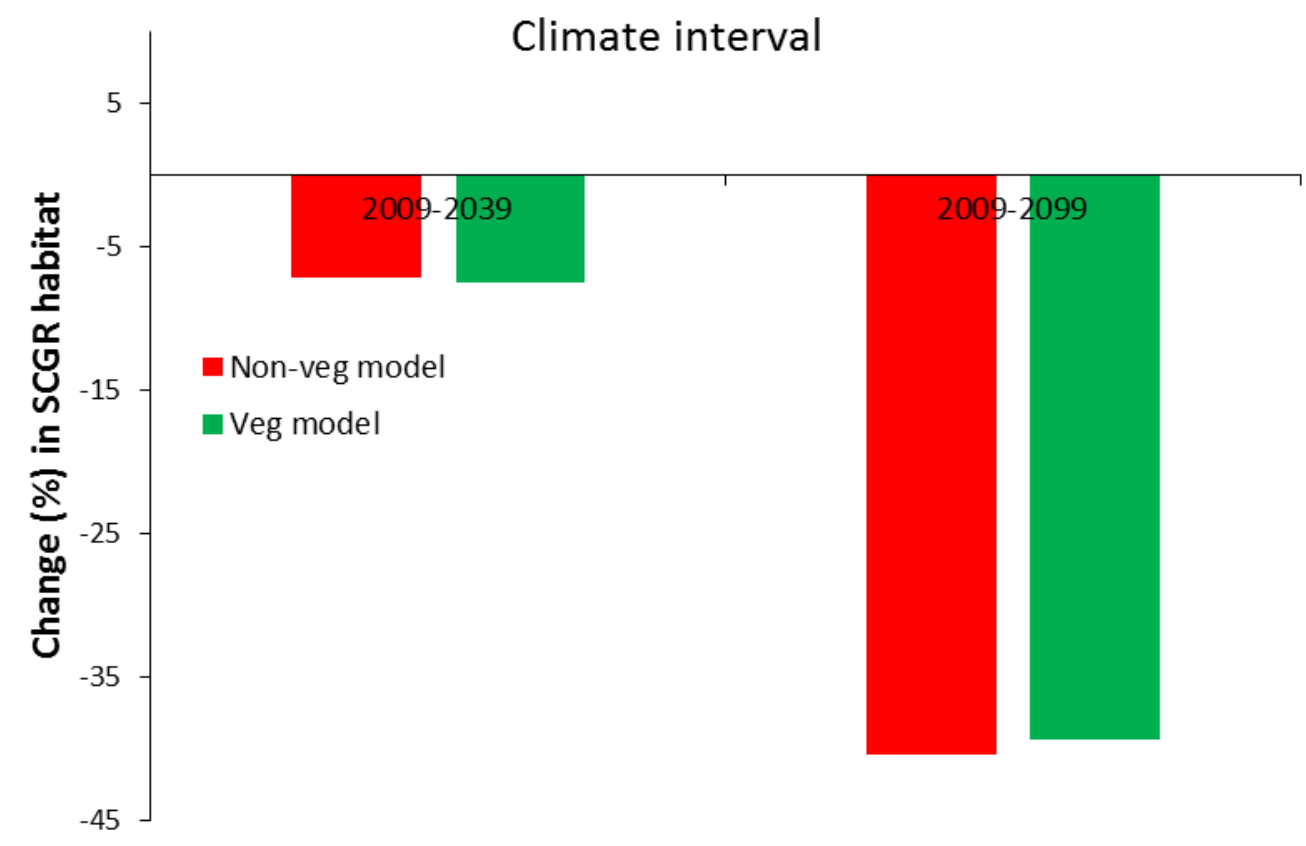

Figure 5.5. Measures of range change among two time intervals for the period 2009 through 2099. The change in range extent is shown as a percent of contemporary range. Green bars are results produced by the model that includes the effect of plant species ranges; red bars are results produced by the model that does not include plant range effects. Values were calculated based on areas of agreement of at least 5 of the 6 climate projections. 


\section{Appendix 6. Relationships between Predictor Variables and Projected Range Changes}

Abbreviations for species shown in the following figures are explained in table 1. Variables noted in $\mathrm{x}-$ axis captions are explained in table 2.

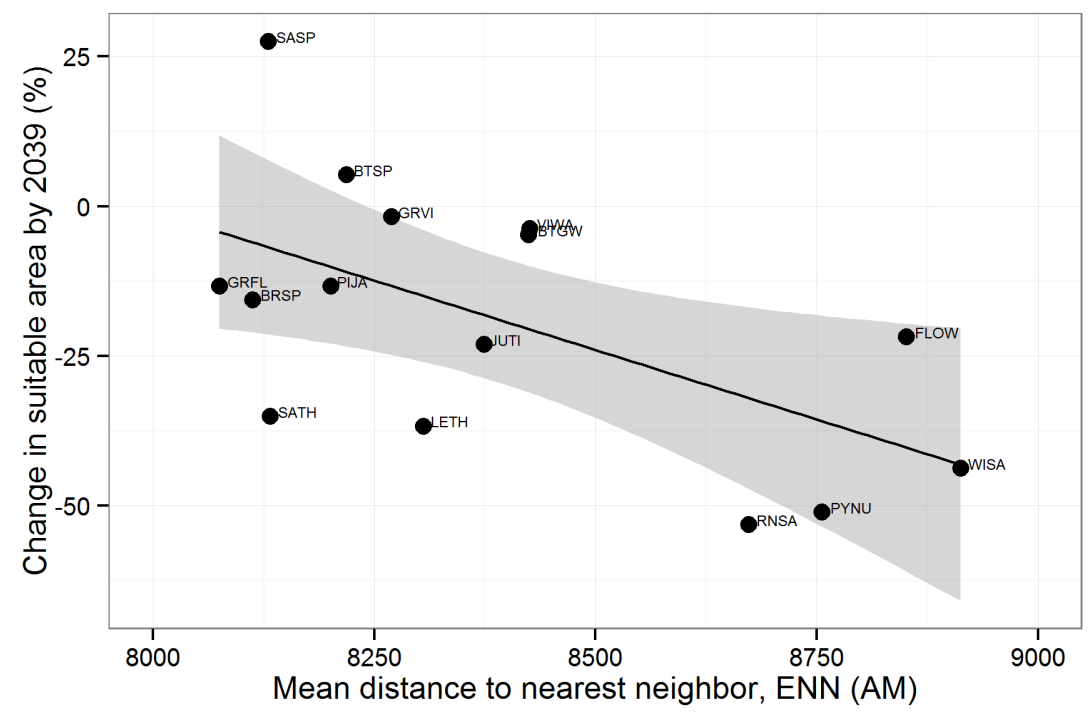

Figure 6.1. Relationship between mean distance to nearest neighboring patch (year 2009) and projected range changes (year 2039) for 15 bird species. The gray band is a 95 percent confidence interval for the slope of the regression line. The adjusted $\mathrm{R}^{2}$ is 34 percent.

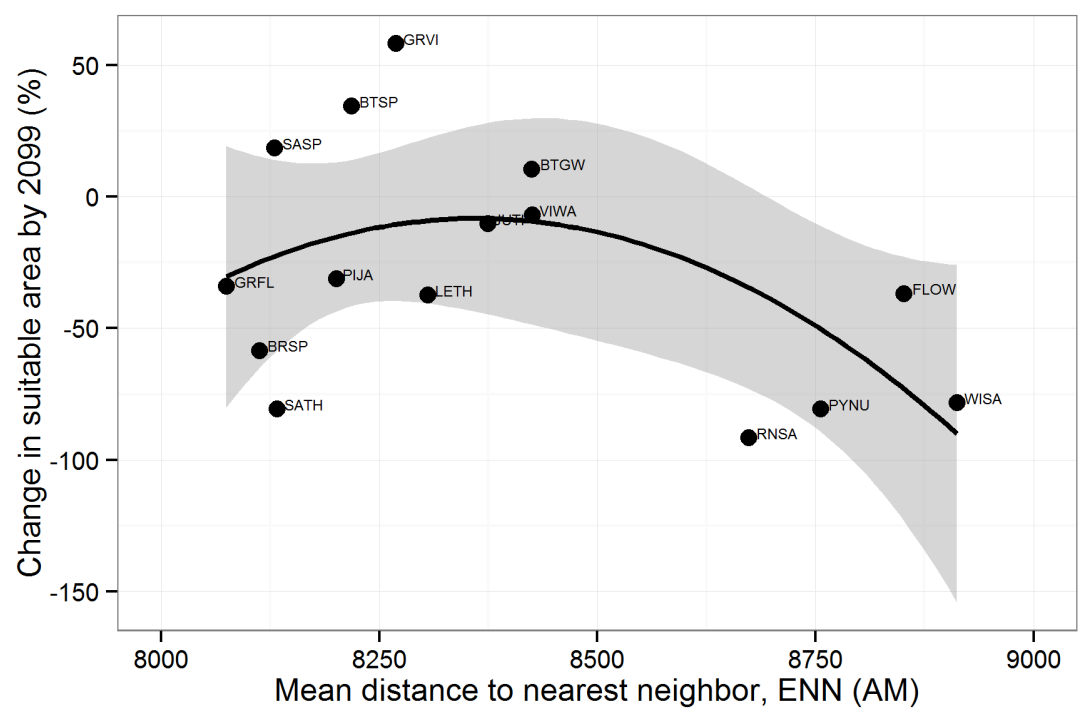

Figure 6.2. Relationship between mean distance to nearest neighboring patch (year 2009) and projected range changes (year 2099) for 15 bird species. The gray band is a 95 percent confidence interval for the slope of the regression line. The adjusted $R^{2}$ is 30 percent. 


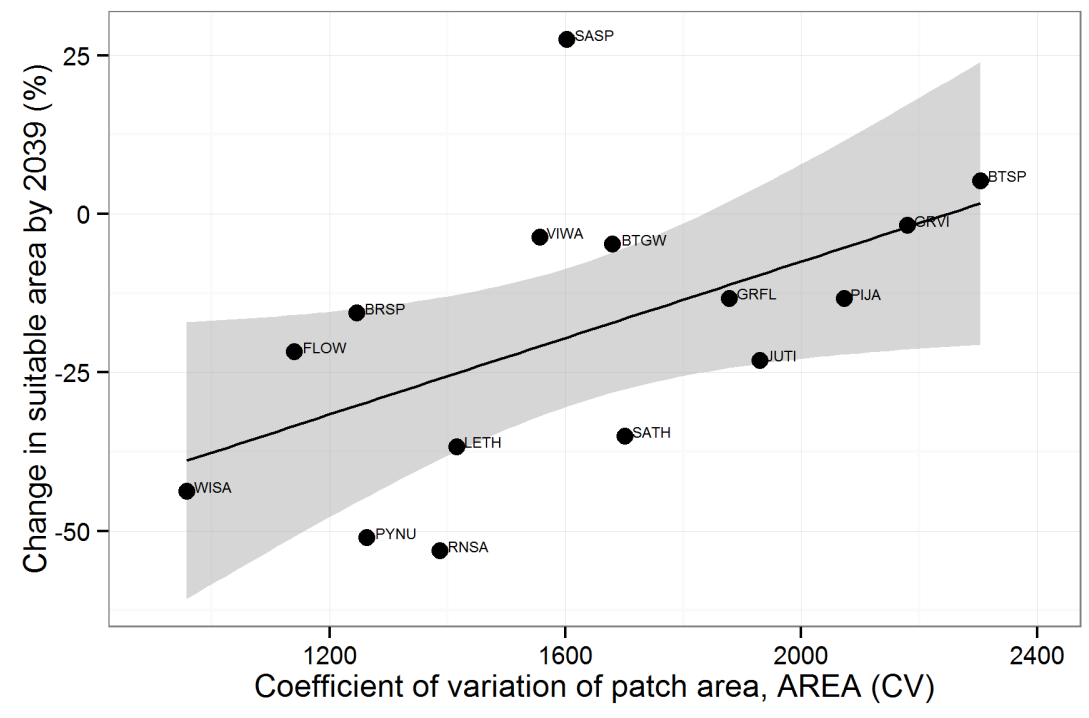

Figure 6.3. Relationship between patch area variability (year 2009) and projected range changes (year 2039) for 15 bird species. The gray band is a 95 percent confidence interval for the slope of the regression line. The adjusted $R^{2}$ is 29 percent.

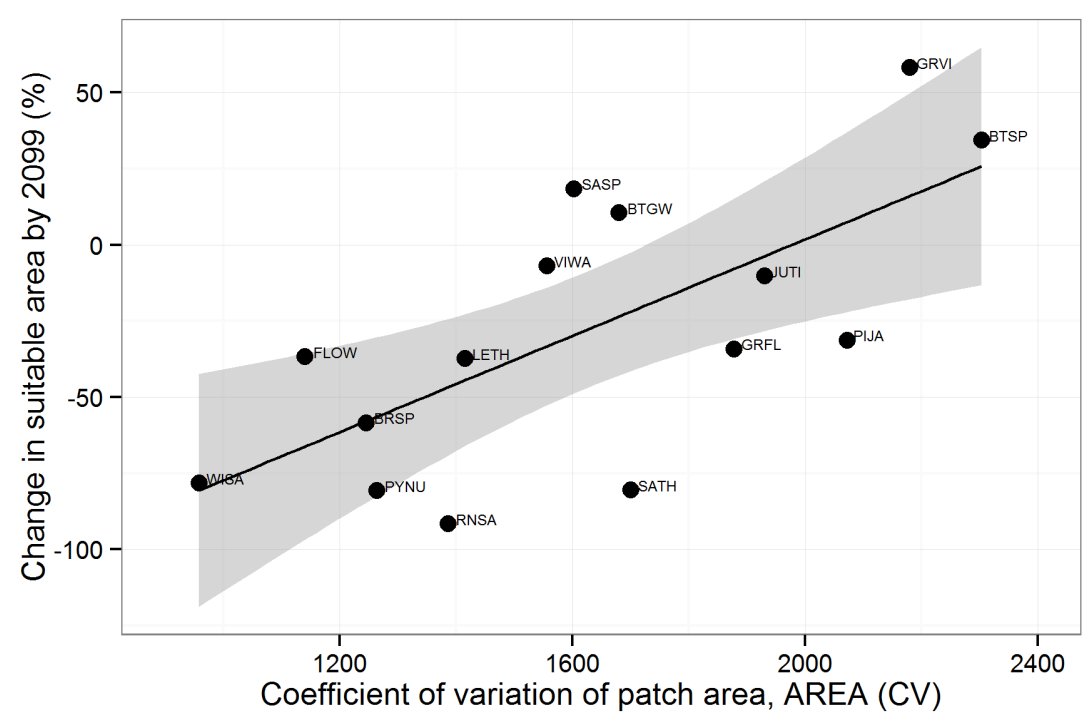

Figure 6.4. Relationship between patch area variability (year 2009) and projected range changes (year 2099) for 15 bird species. The gray band is a 95 percent confidence interval for the slope of the regression line. The adjusted $R^{2}$ is 47 percent. 


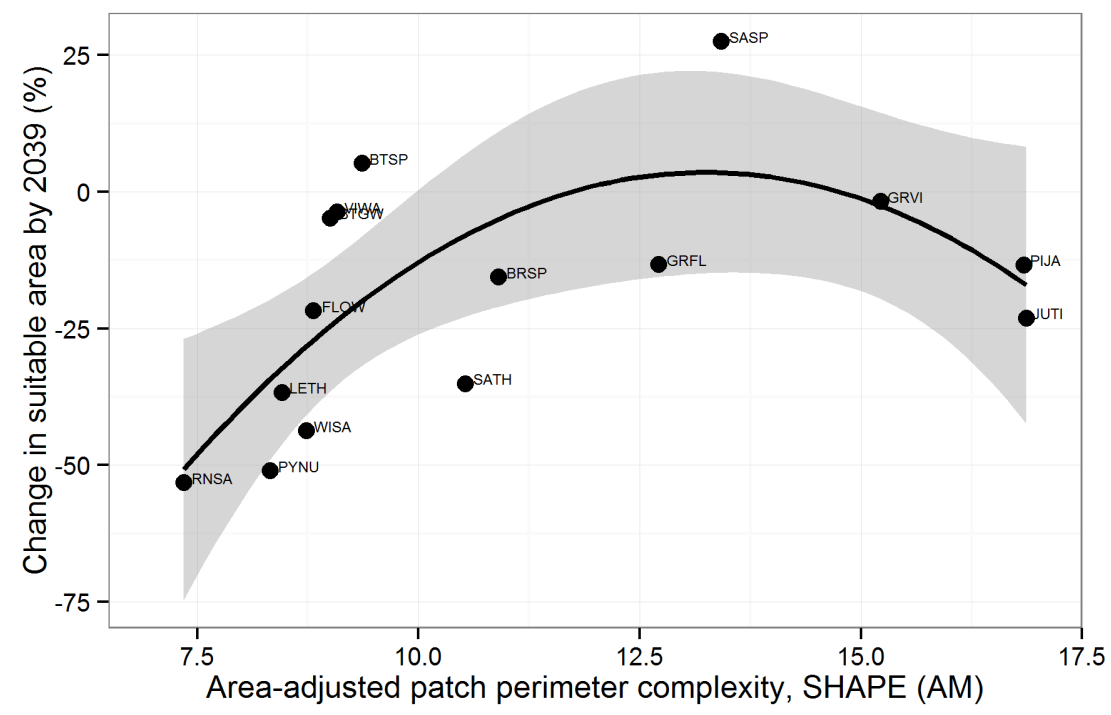

Figure 6.5. Relationship between area-adjusted patch perimeter complexity (year 2009) and projected range changes (year 2039) for 15 bird species. The gray band is a 95 percent confidence interval for the slope of the regression line. The adjusted $R^{2}$ is 46 percent.

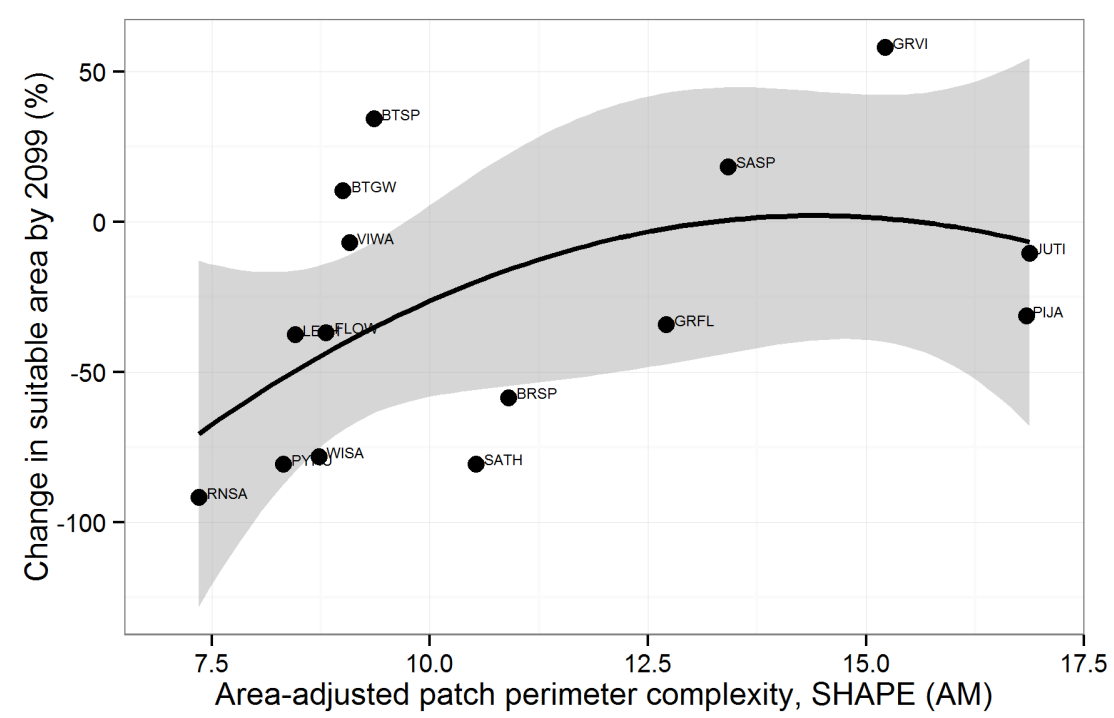

Figure 6.6. Relationship between area-adjusted patch perimeter complexity (year 2009) and projected range changes (year 2099) for 15 bird species. The gray band is a 95 percent confidence interval for the slope of the regression line. The adjusted $R^{2}$ is 25 percent. 


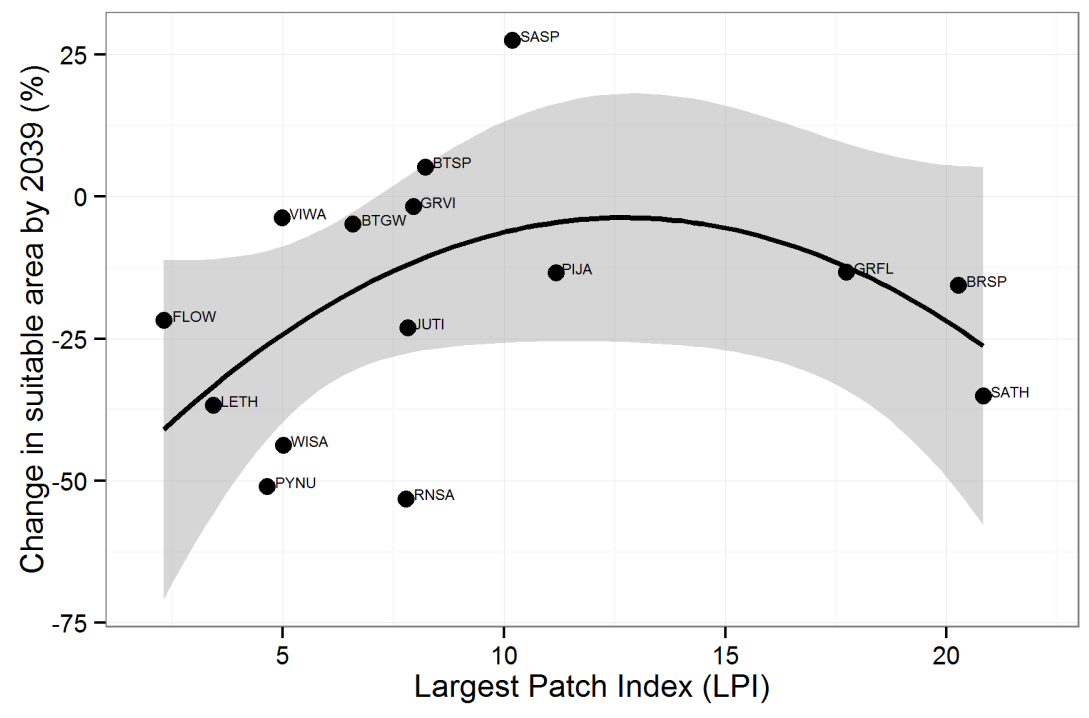

Figure 6.7. Relationship between largest patch index (year 2009) and projected range changes (year 2039) for 15 bird species. The gray band is a 95 percent confidence interval for the slope of the regression line. The adjusted $R^{2}$ is 22 percent.

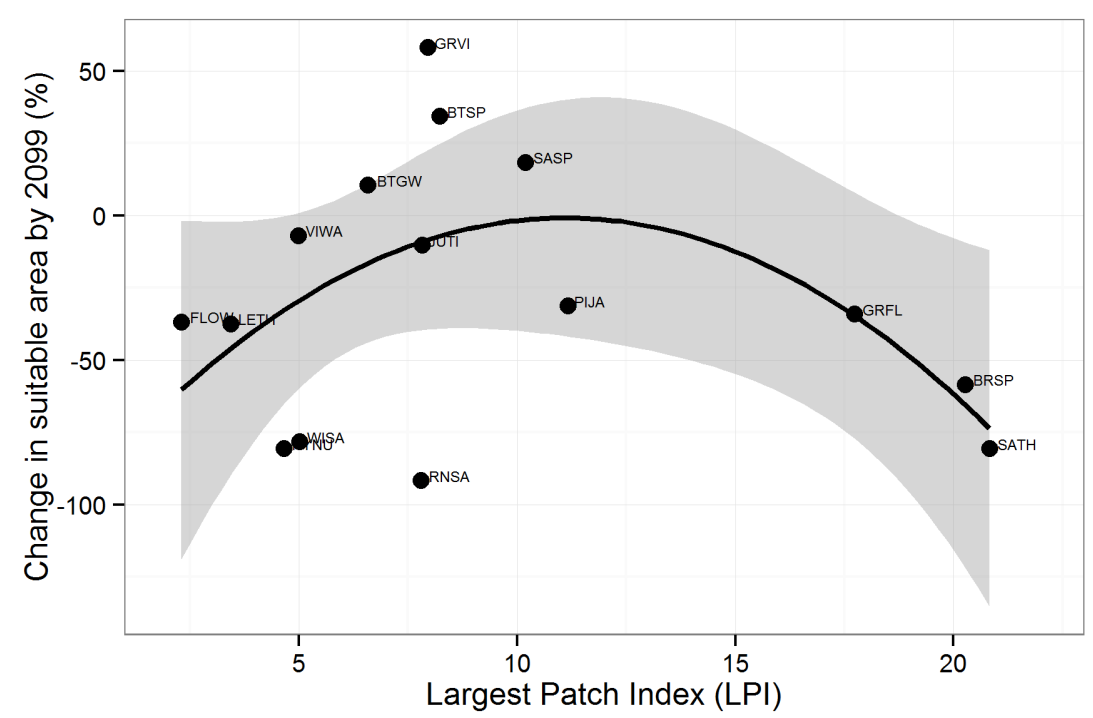

Figure 6.8. Relationship between largest patch index (year 2009) and projected range changes (year 2099) for 15 bird species. The gray band is a 95 percent confidence interval for the slope of the regression line. The adjusted $R^{2}$ is 28 percent. 


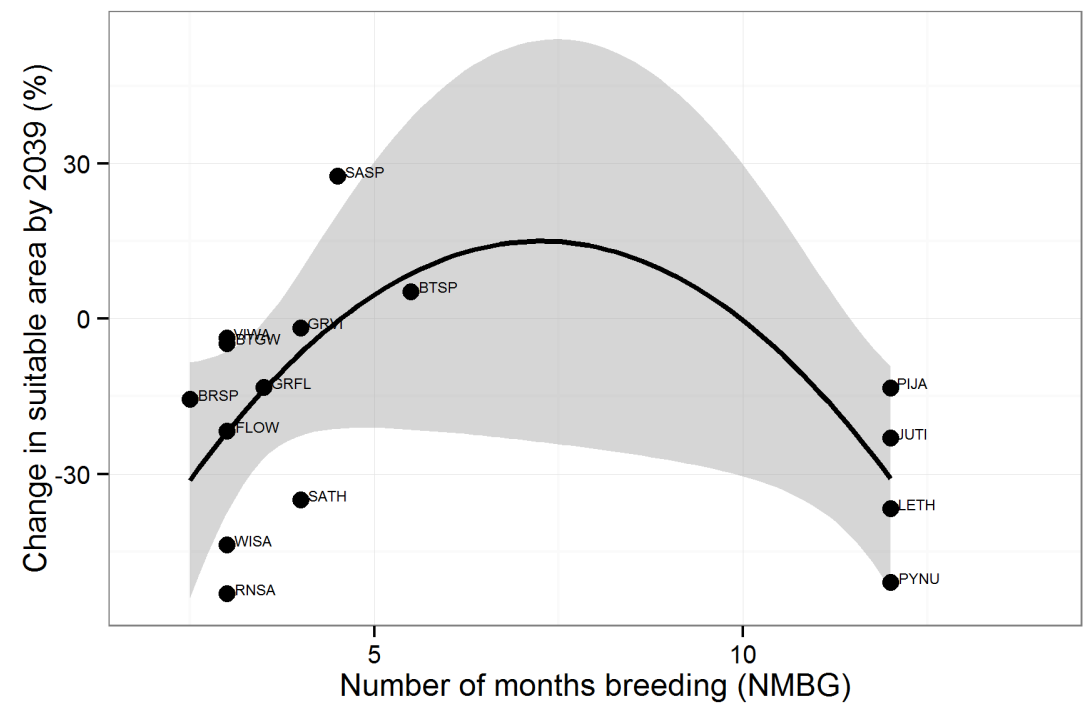

Figure 6.9. Relationship between number of months on the breeding grounds (year 2009) and projected range changes (year 2039) for 15 bird species. The gray band is a 95 percent confidence interval for the slope of the regression line. The adjusted $R^{2}$ is 32 percent.

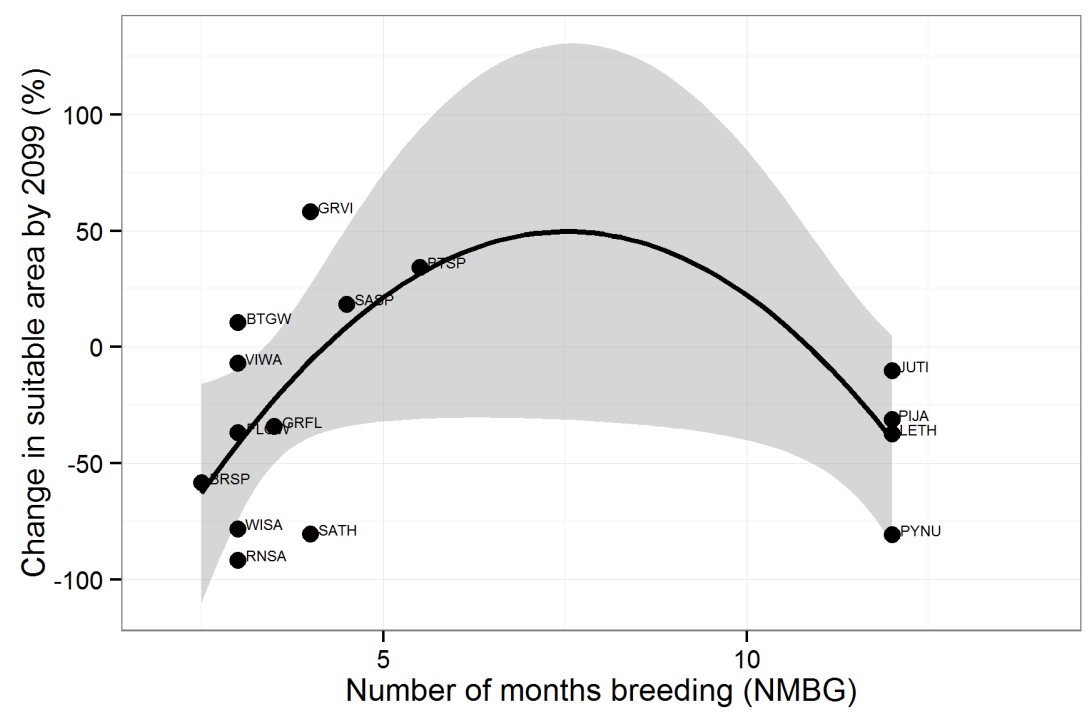

Figure 6.10. Relationship between number of months on the breeding grounds (year 2009) and projected range changes (year 2099) for 15 bird species. The gray band is a 95 percent confidence interval for the slope of the regression line. The adjusted $R^{2}$ is 30 percent. 


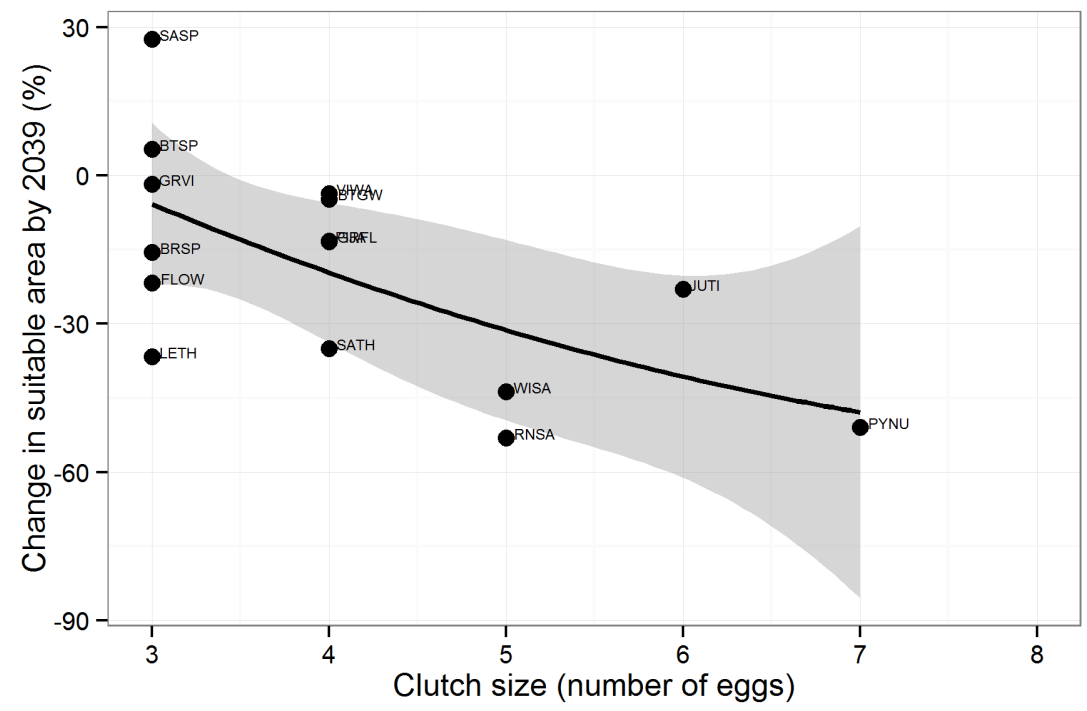

Figure 6.11. Relationship between clutch size (year 2009) and projected range changes (year 2039) for 15 bird species. The gray band is a 95 percent confidence interval for the slope of the regression line. The adjusted $R^{2}$ is 38 percent.

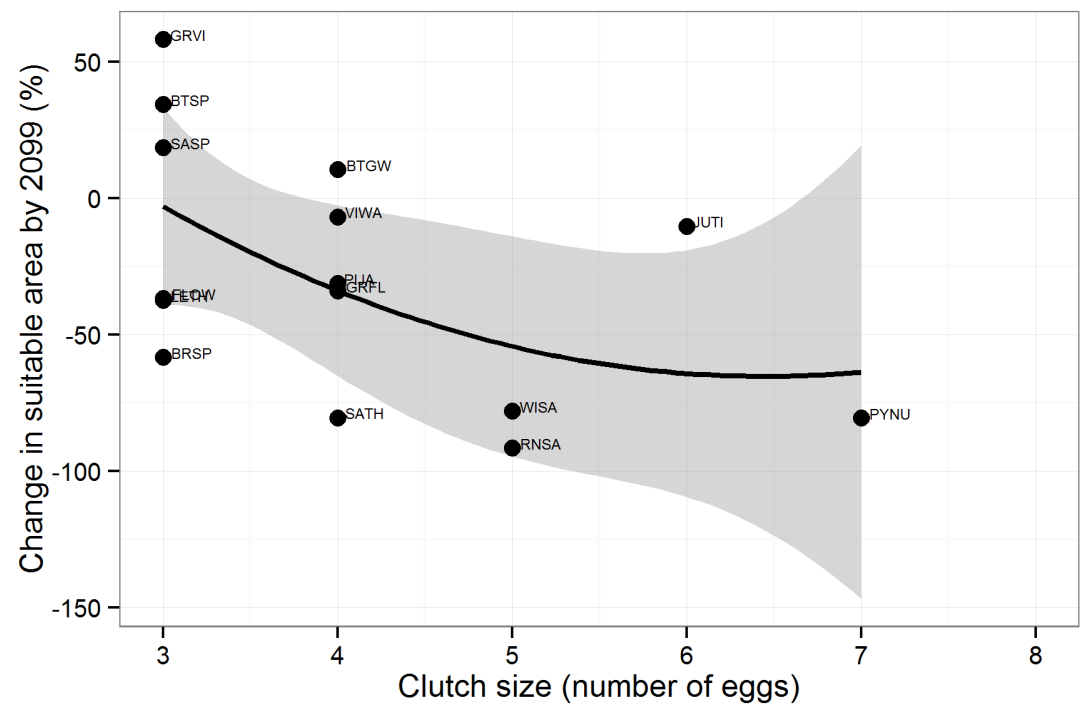

Figure 6.12. Relationship between clutch size (year 2009) and projected range changes (year 2099) for 15 bird species. The gray band is a 95 percent confidence interval for the slope of the regression line. The adjusted $R^{2}$ is 27 percent. 


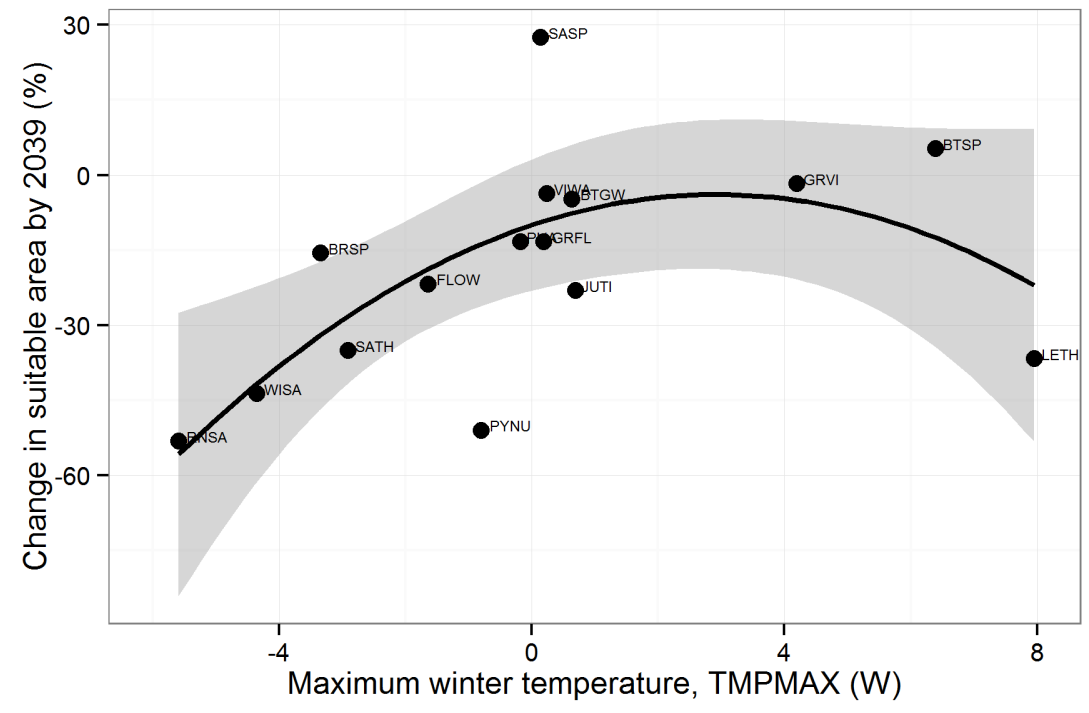

Figure 6.13. Relationship between average maximum winter temperature (year 2009) and projected range changes (year 2039) for 15 bird species. The gray band is a 95 percent confidence interval for the slope of the regression line. The adjusted $R^{2}$ is 47 percent.

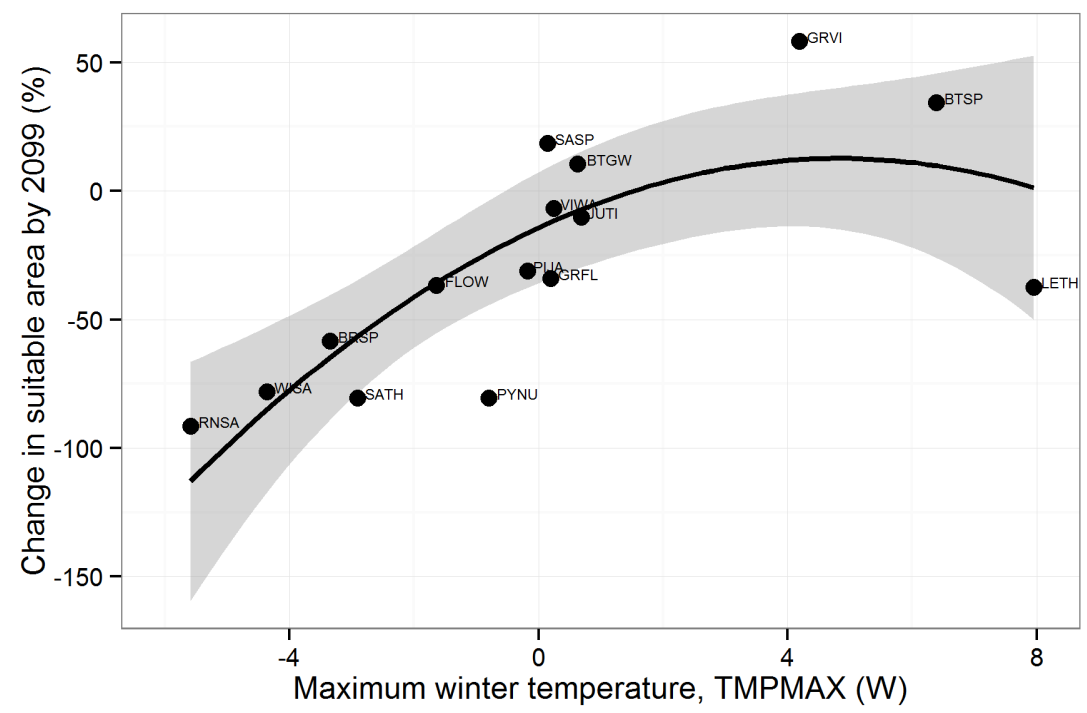

Figure 6.14. Relationship between average maximum winter temperature (year 2009) and projected range changes (year 2099) for 15 bird species. The gray band is a 95 percent confidence interval for the slope of the regression line. The adjusted $R^{2}$ is 64 percent. 


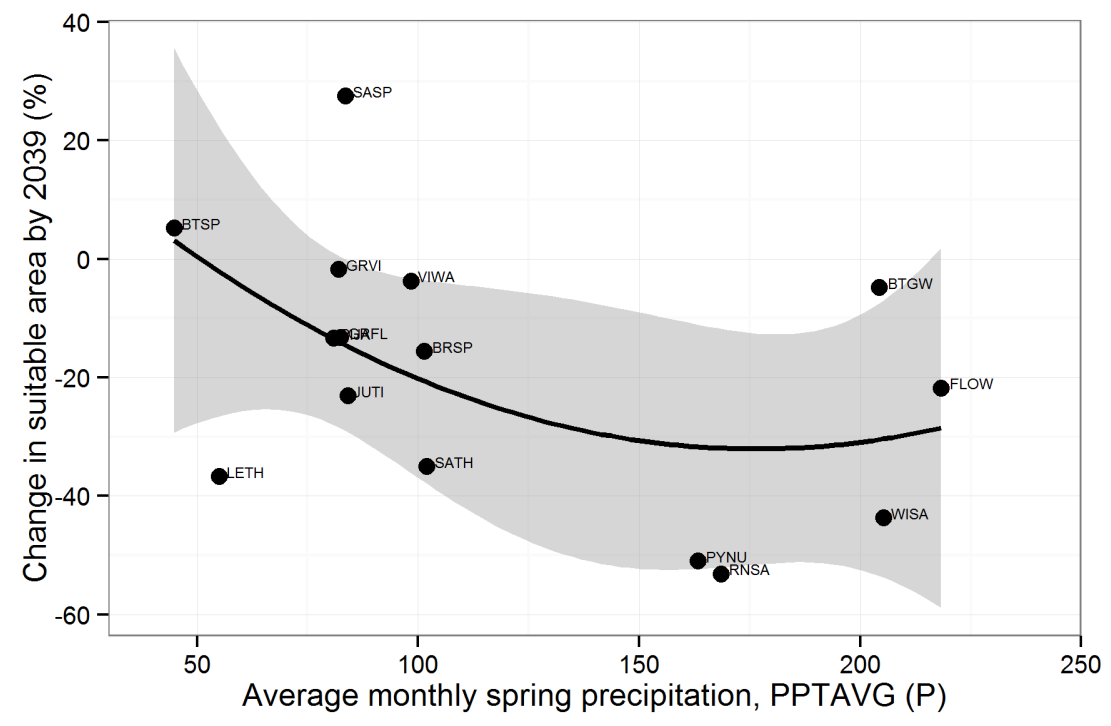

Figure 6.15. Relationship between average monthly spring precipitation (year 2009) and projected range changes (year 2039) for 15 bird species. The gray band is a 95 percent confidence interval for the slope of the regression line. The adjusted $R^{2}$ is 23 percent.

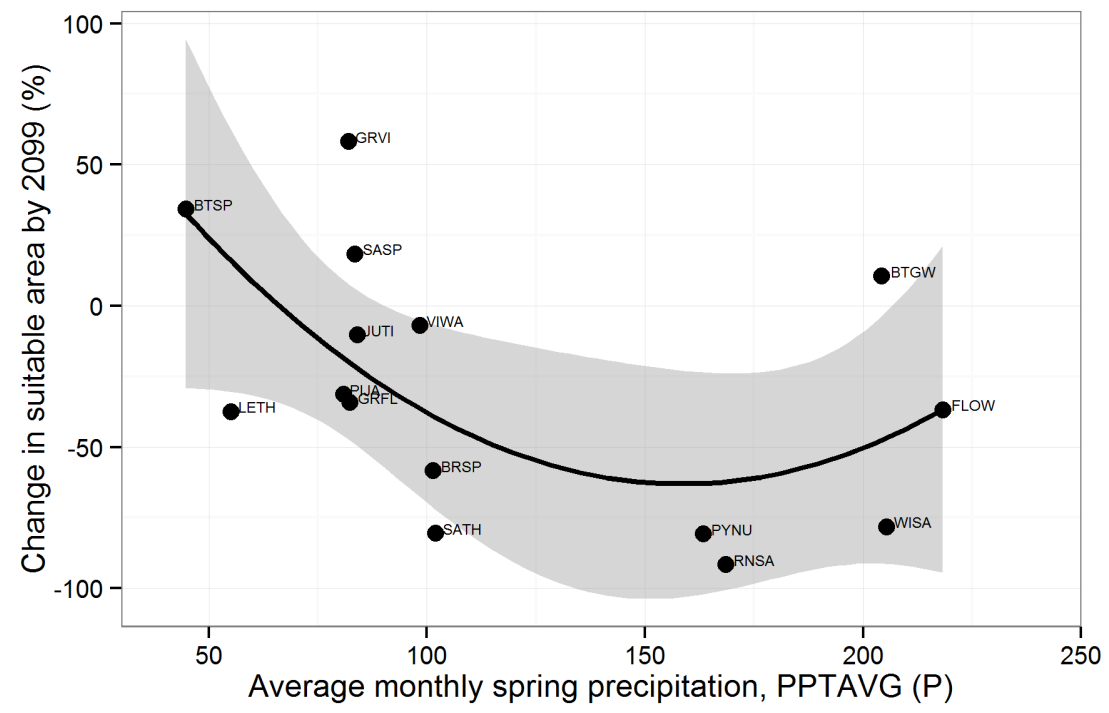

Figure 6.16. Relationship between average monthly spring precipitation (year 2009) and projected range changes (year 2099) for 15 bird species. The gray band is a 95 percent confidence interval for the slope of the regression line. The adjusted $R^{2}$ is 33 percent. 


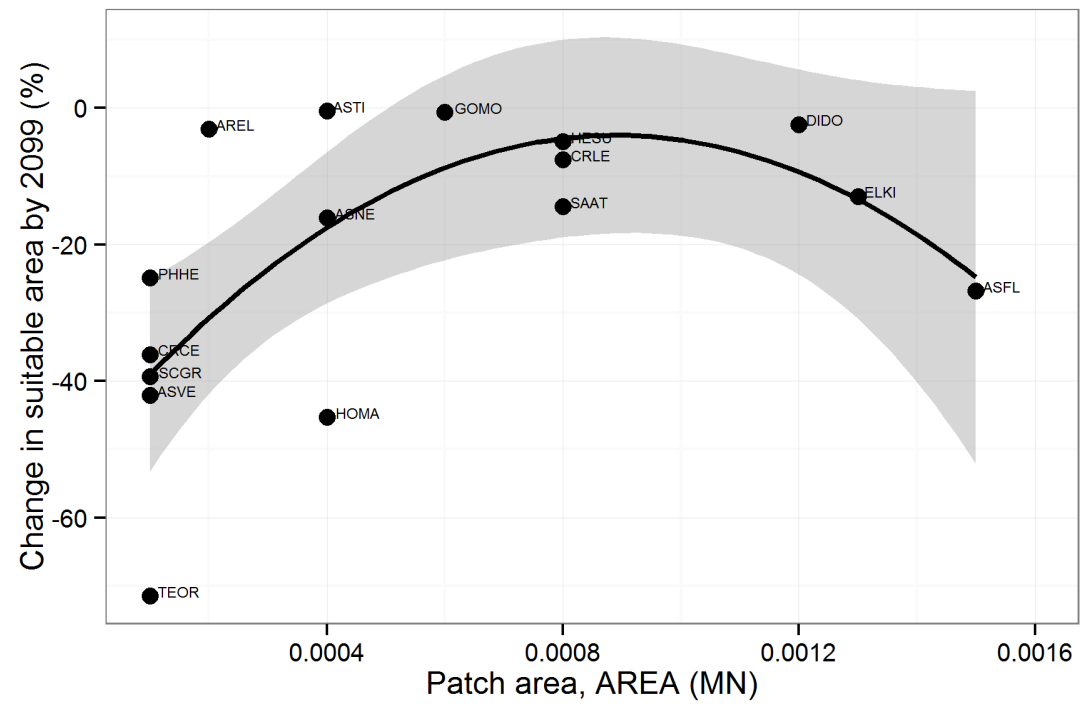

Figure 6.17. Relationship between mean patch area (year 2009) and projected range changes (year 2099) for 16 reptile species. The gray band is a 95 percent confidence interval for the slope of the regression line. The adjusted $R^{2}$ is 47 percent.

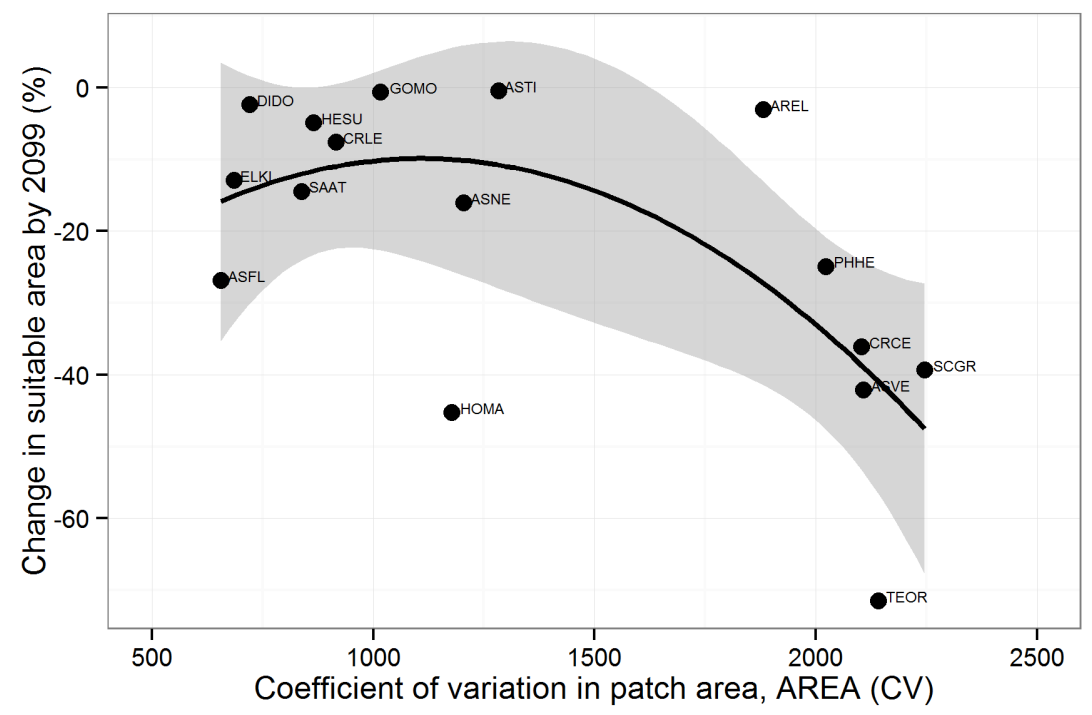

Figure 6.18. Relationship between coefficient of variation in patch area (year 2009) and projected range changes (year 2099) for 16 reptile species. The gray band is a 95 percent confidence interval for the slope of the regression line. The adjusted $R^{2}$ is 44 percent. 


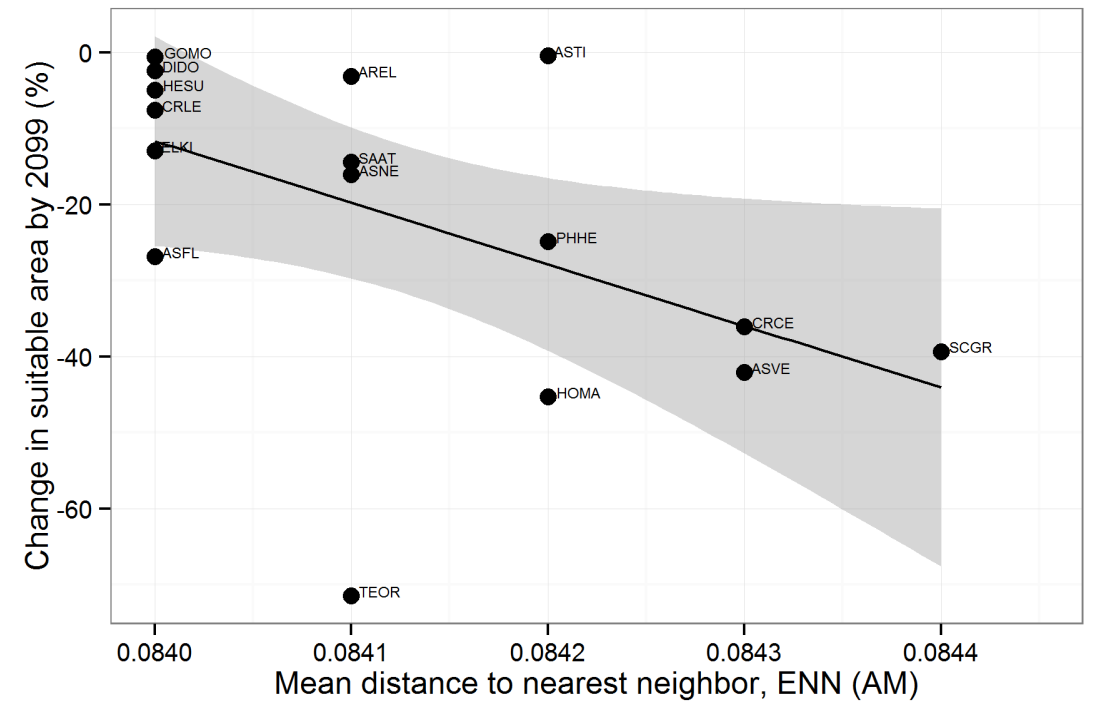

Figure 6.19. Relationship between mean distance to nearest neighboring patch (year 2009) and projected range changes (year 2099) for 16 reptile species. The gray band is a 95 percent confidence interval for the slope of the regression line. The adjusted $R^{2}$ is 27 percent.

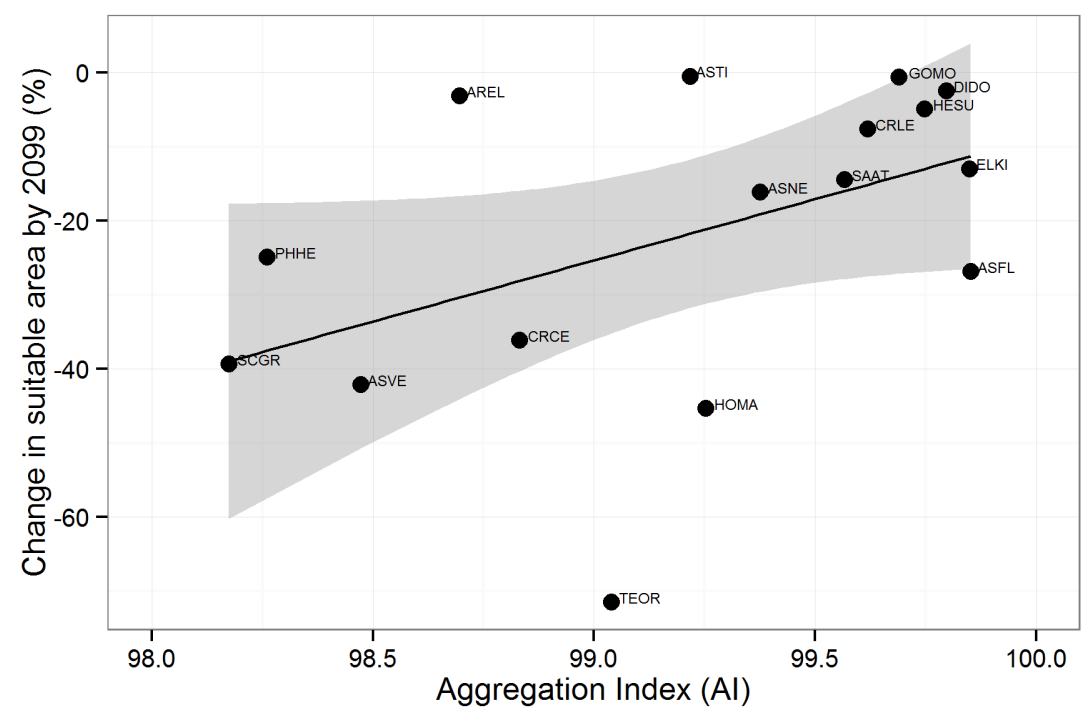

Figure 6.20. Relationship between patch aggregation index (year 2009) and projected range changes (year 2099) for 16 reptile species. The gray band is a 95 percent confidence interval for the slope of the regression line. The adjusted $R^{2}$ is 25 percent. 


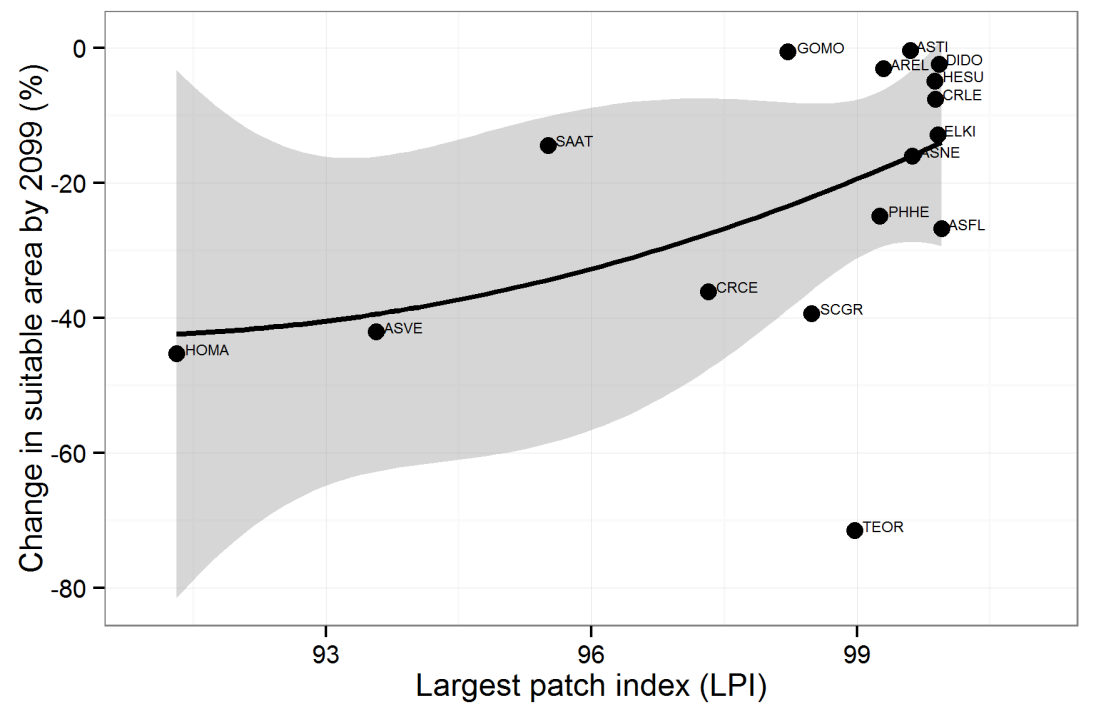

Figure 6.21. Relationship between largest patch index (year 2009) and projected range changes (year 2099) for 16 reptile species. The gray band is a 95 percent confidence interval for the slope of the regression line. The adjusted $R^{2}$ is 21 percent.

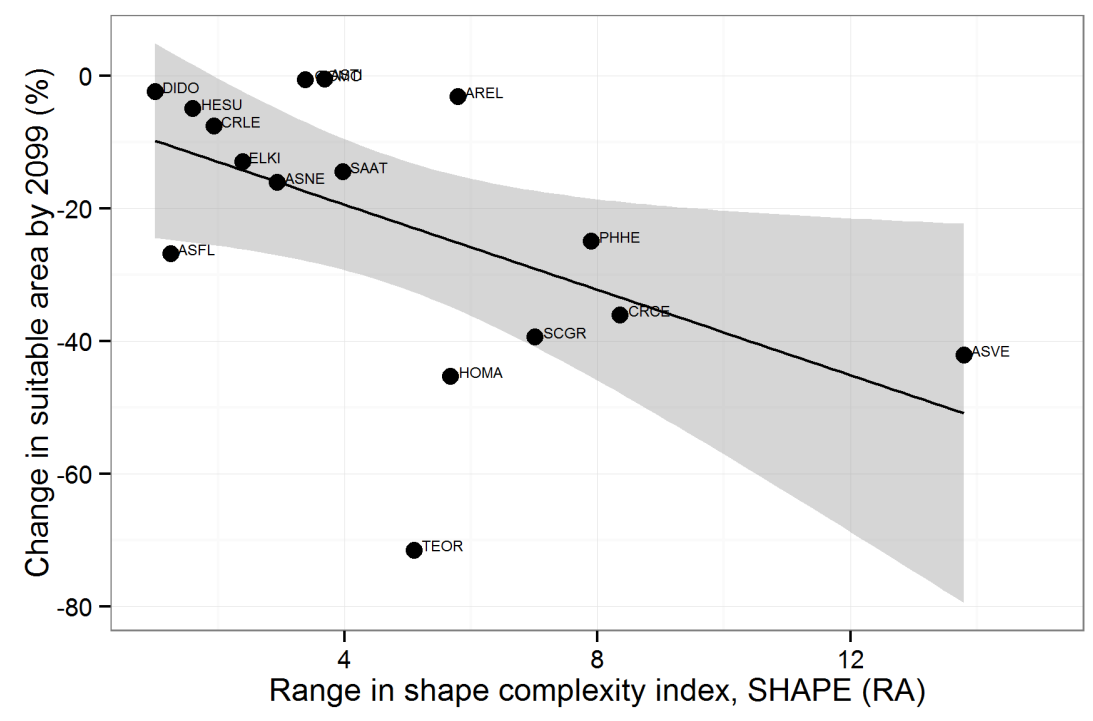

Figure 6.22. Relationship between range in shape complexity index (year 2009) and projected range changes (year 2099) for 16 reptile species. The gray band is a 95 percent confidence interval for the slope of the regression line. The adjusted $R^{2}$ is 31 percent. 


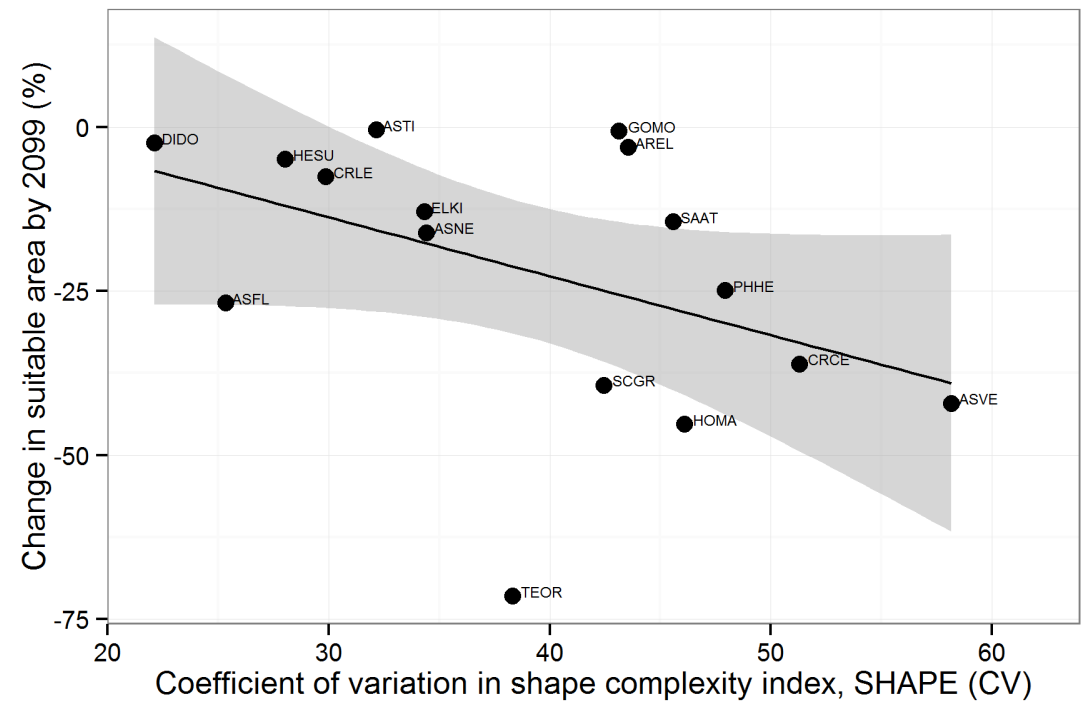

Figure 6.23. Relationship between coefficient of variation in shape complexity index (year 2009) and projected range changes (year 2099) for 16 reptile species. The gray band is a 95 percent confidence interval for the slope of the regression line. The adjusted $R^{2}$ is 20 percent.

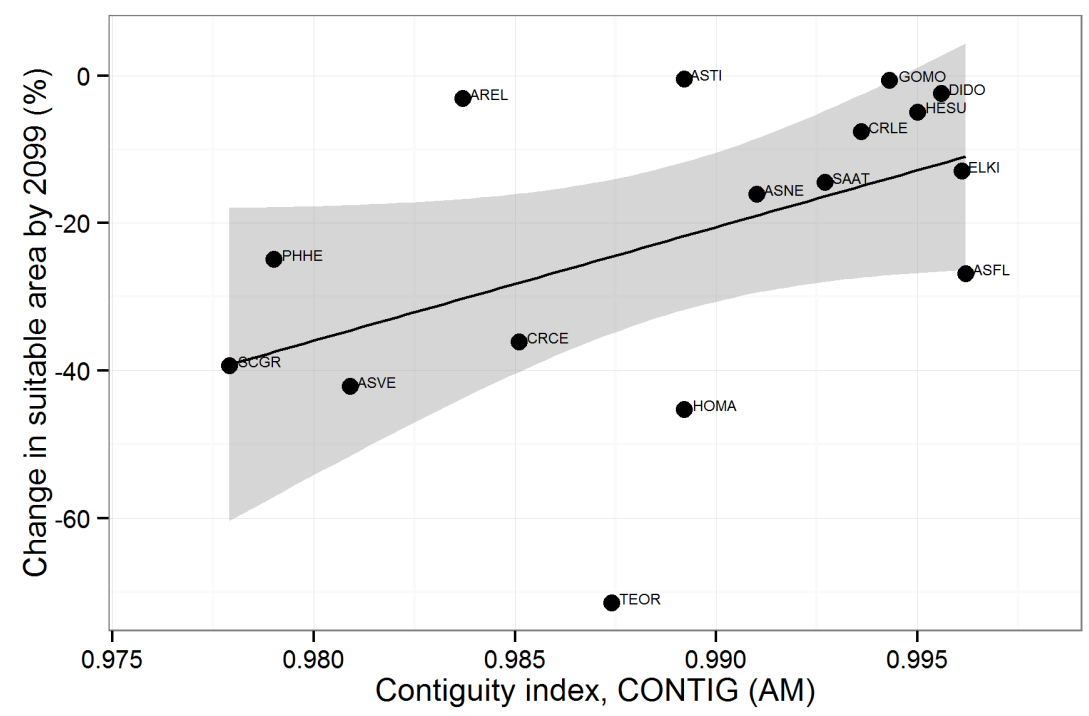

Figure 6.24. Relationship between the patch contiguity index (year 2009) and projected range changes (year 2099) for 16 reptile species. The gray band is a 95 percent confidence interval for the slope of the regression line. The adjusted $R^{2}$ is 25 percent. 
Publishing support provided by the U.S. Geological Survey

Science Publishing Network, Tacoma Publishing Service Center

For more information concerning the research in this report, contact the Director, Western Fisheries Research Center U.S. Geological Survey

6505 NE 65th Street

Seattle, Washington 98115

http://wfrc.usgs.gov/ 
